\title{
The hedgehog pathway in basal cell carcinoma
}

Citation for published version (APA):

Reinders, M. G. H. C. (2019). The hedgehog pathway in basal cell carcinoma: target for diagnostics and therapy. [Doctoral Thesis, Maastricht University]. Maastricht University. https://doi.org/10.26481/dis.20190215mr

Document status and date:

Published: 01/01/2019

DOI:

10.26481/dis.20190215mr

Document Version:

Publisher's PDF, also known as Version of record

\section{Please check the document version of this publication:}

- A submitted manuscript is the version of the article upon submission and before peer-review. There can be important differences between the submitted version and the official published version of record.

People interested in the research are advised to contact the author for the final version of the publication, or visit the DOI to the publisher's website.

- The final author version and the galley proof are versions of the publication after peer review.

- The final published version features the final layout of the paper including the volume, issue and page numbers.

Link to publication

\footnotetext{
General rights rights.

- You may freely distribute the URL identifying the publication in the public portal. please follow below link for the End User Agreement:

www.umlib.nl/taverne-license

Take down policy

If you believe that this document breaches copyright please contact us at:

repository@maastrichtuniversity.nl

providing details and we will investigate your claim.
}

Copyright and moral rights for the publications made accessible in the public portal are retained by the authors and/or other copyright owners and it is a condition of accessing publications that users recognise and abide by the legal requirements associated with these

- Users may download and print one copy of any publication from the public portal for the purpose of private study or research.

- You may not further distribute the material or use it for any profit-making activity or commercial gain

If the publication is distributed under the terms of Article $25 \mathrm{fa}$ of the Dutch Copyright Act, indicated by the "Taverne" license above, 

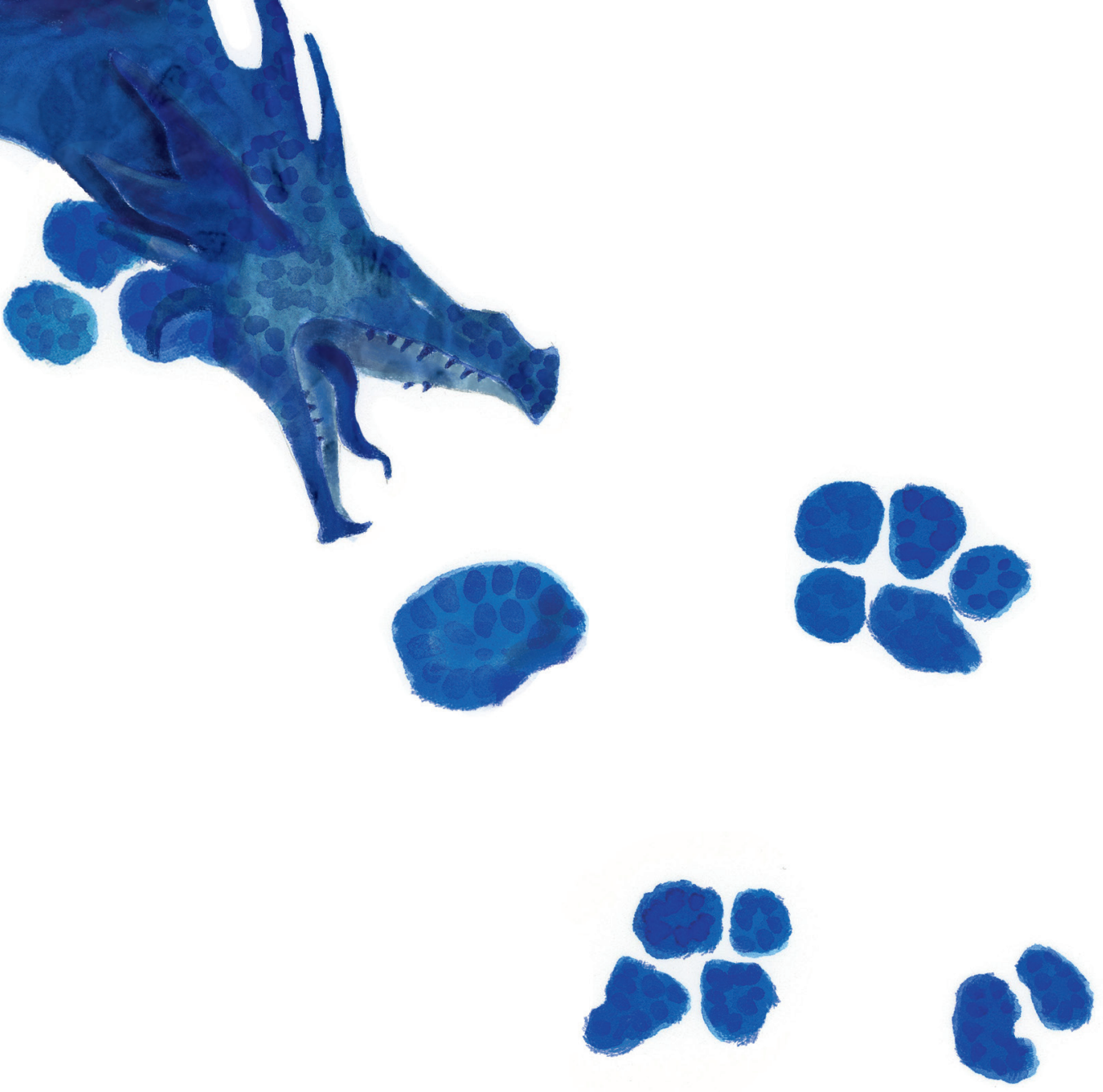

The hedgehog pathway

in basal cell carcinoma

Target for diagnostics and therapy

Marieke Reinders 


\section{The hedgehog pathway in basal cell carcinoma Target for diagnostics and therapy}


Copyright:

Cover design and layout:

Printing:

ISBN:
Marieke Reinders, Maastricht 2019

(C) evelienjagtman.com

Gildeprint

978-94-6323-461-0

The publication of this thesis was kindly supported by the Maastricht University Medical Centre and Maastricht University. 


\section{The hedgehog pathway in basal cell carcinoma Target for diagnostics and therapy}

PROEFSCHRIFT

ter verkrijging van de graad van doctor aan de Universiteit Maastricht, op gezag van de Rector Magnificus, Prof. dr. Rianne M. Letschert volgens het besluit van het College van Decanen,

in het openbaar te verdedigen op vrijdag 15 februari 2019 om 14.00 uur

door

Marie Gertruud Hélène Carolien Reinders

Geboren 18 oktober 1982 te Deurne 


\section{Promotor}

Prof. dr. P.M. Steijlen

\section{Copromotores}

Dr. K. Mosterd

Dr. M. van Geel

\section{Beoordelingscommissie}

Prof. dr. C.T.R.M. Stumpel (voorzitter)

Prof. dr. S.G.M.A. Pasmans (Erasmus Medisch Centrum Rotterdam)

Prof. dr. I.B. Tan

Prof. dr. V.C.G. Tjan-Heijnen

Prof. dr. R. Willemze (Leids Universitair Medisch Centrum) 
Voor mijn ouders 



\section{Contents}

Chapter 1 General introduction 9

$\begin{array}{lll}\text { Part one } & \text { Basal cell naevus syndrome } & 27\end{array}$

Chapter 2 New mutations and an updated database for the patched-1 (PTCH1) gene 29

Chapter 3 A genotype-phenotype study in basal cell naevus syndrome: a Dutch 41 multicentre retrospective cohort study and review of the literature

Chapter 4 Postzygotic mosaicism in basal cell naevus syndrome 57

Chapter 5 Genetic profiling of basal cell carcinomas detects postzygotic 67 mosaicism in basal cell naevus syndrome

\section{Part two Treatment of locally advanced and metastatic basal cell carcinoma $\quad 79$} with vismodegib

Chapter 6 Vismodegib in metastasised basal cell carcinoma 81

Chapter $7 \quad$ Vismodegib for basal cell carcinoma: targeted therapy in case of locally 91 advanced or metastasised disease

Chapter 8 Acquired resistance to the hedgehog pathway inhibitor vismodegib 105 due to smoothened mutations in treatment of locally advanced basal cell carcinoma.

Chapter 9 Epidermal cyst formation and hyperkeratosis in a patient treated with vismodegib for locally advanced basal cell carcinoma

Chapter 10 Summary, discussion, future perspectives and valorisation 121

Chapter 11 Samenvatting 135

$\begin{array}{ll}\text { Addendum } & 141\end{array}$

Curriculum vitae 143

List of publications and presentations $\quad 145$

Dankwoord 149 



\section{Chapter 1}

General introduction 



\section{General introduction}

Insight into the pathogenesis of rare genetic disorders increases our understanding of the pathogenesis of common diseases. For example, in dermatology the discovery of filaggrin mutations in ichthyosis provided a key to unravel the pathogenesis of eczema. ${ }^{1}$ Genetic studies on patients with basal cell naevus syndrome (BCNS) eventually led to the identification of inactivating mutations in the human homolog of the Drosophila patched-1 gene (PTCH1), the genetic defect underlying this syndrome. At the same time, it turned out that sporadic basal cell carcinoma (BCC) has the same genetic signature as BCNS. ${ }^{2,3}$ Increased knowledge of the genetic basis of cancer helps us to understand its complex nature. This information can lead to the development of targeted cancer treatments. The genetic basis of BCC is the leading thread of this thesis. The first part focuses on the underlying genetics of BCNS. The second part gives an overview of targeted therapy for BCC with the hedgehog pathway inhibitor vismodegib and the mechanism of the development of resistance for this therapy.

\section{Basal cell carcinoma}

$\mathrm{BCC}$ is the most common cancer among Caucasians, with an increasing incidence of 3-10\% per year. ${ }^{4,5}$ BCC c classically appear as slow-growing, translucent, elevated lesions on the sunexposed skin (Figure 1.1). In the Netherlands 37,500 new patients were diagnosed with BCC in 2014. Ageing of the population is not the only cause of this rising number, since especially the number of young women with BCC is growing. ${ }^{4}$ Changing sun bathing behaviour plays an important role, as the major risk factor for BCC is exposure to ultraviolet (UV) radiation. It is estimated that one in five to six Dutch inhabitants will develop at least one BCC during lifetime. ${ }^{6}$ About 30\% of these patients will develop more than one BCC. ${ }^{7}$ The majority of BCCs is easy to treat by conventional excision or Mohs' micrographic surgery. Non-invasive treatments, like topical imiquimod cream, 5-fluorouracil cream and photodynamic therapy, are an option in case of superficial tumour growth. ${ }^{8}$ Radiotherapy is a good alternative when patients are ineligible for surgery. ${ }^{9}$ Longstanding untreated or undertreated tumours can develop into a locally advanced BCC. In these cases, curative treatment with surgery or radiotherapy may be impossible because of technical restrictions or mutilating and functional side effects. BCC is a slow-growing tumour with a very low risk of metastasis (0.003-0.55\%). Metastasised BCC however has a poor prognosis with a median survival of 8-10 months, if left untreated. ${ }^{10}$ Treatment with conventional chemotherapy or radiotherapy has been described in case reports and series, but no clinical trials are available and despite treatment, prognosis seems to remain poor. ${ }^{11}$ Aggressive locoregional treatment with primary surgery or radiotherapy, or both, may be effective in patients with only locoregional disease. ${ }^{12}$ 


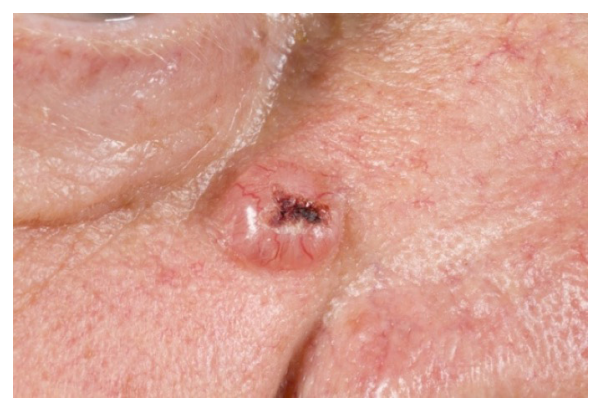

Figure 1.1. Typical basal cell carcinoma on the right cheek.

\section{Hedgehog signalling pathway}

The PTCH1 gene is the human homolog of the Drosophila patched-1 gene and is located on chromosome 9q22.3. It encodes a 1447-amino acid transmembrane glyco-protein, which is part of the hedgehog $(\mathrm{Hh})$ signalling pathway. The Hh pathway is a key regulator in embryonic development and tumorigenesis controlling cell differentiation, tissue polarity and cell proliferation. The function of the PTCH1 protein is inhibition of the transmembrane protein smoothened (SMO). In the presence of active Hh ligands, binding to the PTCH1 receptor leads to release of this inhibition, allowing SMO to signal downstream and activate the glioma-associated oncogene (GLI) family of transcription factors. GLI transcription factors are inhibited in part by suppressor of fused (SUFU), which controls their nuclear entry and transcriptional effects (Figure 1.2a).
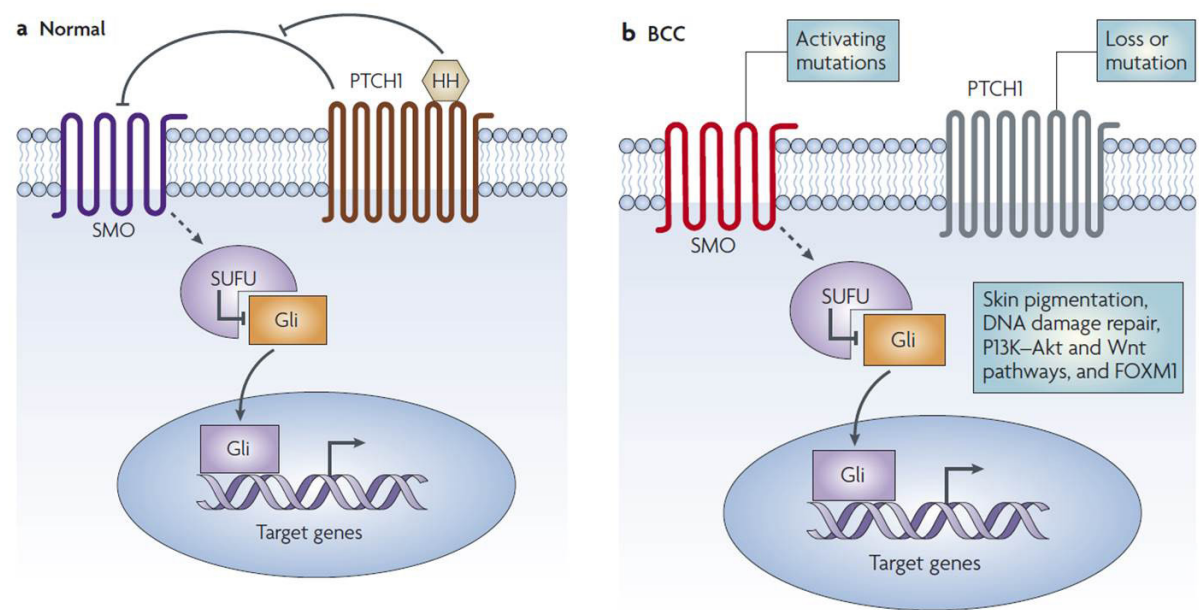

Figure 1.2. Hedgehog signalling pathway in a) embryonic development b) basal cell carcinoma. ${ }^{13}$ 
Based on its role in preventing cells from uncontrolled proliferation, PTCH1 is considered as a tumour suppressor gene. SMO on the other hand acts as an oncogene. Deregulation of the Hh signalling pathway seems to be the primary event in the pathogenesis of BCC (Figure 1.2b). About $85 \%$ of sporadic BCCs carry mutations in genes from the Hh pathway, including PTCH1 in 70\%, activating SMO mutations in 10-20\% and SUFU in about 8\%. ${ }^{13-15}$ Aberrant activation of the Hh pathway has been shown in a variety of other human cancers, including malignant glioma, medulloblastoma, leukaemia, and cancer of the breast, lung, pancreas, and prostate. ${ }^{16}$

\section{Basal cell naevus syndrome}

BCNS (MIM \#109400), also known as Gorlin syndrome, is a rare autosomal dominant disorder characterized by the development of multiple BCCs at a young age, maxillary keratocysts and cerebral calcifications. ${ }^{17}$ Other characteristic symptoms are palmoplantar pits, rib deformities and typical phenotypical features like macrocephaly and frontal bossing. Of the affected individuals, 3-5\% develops a medulloblastoma in early childhood. Diagnosis of BCNS is based on the presence of one major criterion and genetic confirmation, two major criteria, or one major and two minor criteria (Table 1). Diagnostic criteria were first established by Evans et al., modified by Kimonis et al., and revised by Bree in 2011..$^{18-20}$ The incidence of BCNS is estimated at 1 in 50,000 to 256,000.21 In 1996 PTCH1 was firstly reported as a candidate gene for BCNS. Two different heterozygous mutations in the PTCH1 gene were identified in two patients with BCNS. ${ }^{3}$ Now we know that in up to $85 \%$ of BCNS patients a germline mutation in the PTCH1 gene is found.22 Unilateral or segmental BCNS, caused by postzygotic mosaicism, has been described as well. ${ }^{23,24}$ Also, there are few reports of germline mutations in other participants of the Hh pathway like PTCH2 and SUFU. ${ }^{25-27}$ To date, no genotype-phenotype correlation has been demonstrated in BCNS. ${ }^{28,29}$ Patients with a germline mutation in SUFU have a slightly higher risk of developing medulloblastoma in childhood. ${ }^{30}$

The developmental defects in BCNS are likely to be due to haploinsufficiency ${ }^{28}$, while tumours are believed to develop according to the two-hit theory described by Knudson. ${ }^{31}$ The first hit in BCNS is a germline mutation in the PTCH1 gene. The remaining healthy allele is lost by loss of heterozygosity or somatic mutation. In BCNS this second hit is usually UV-induced, leading to BCC development. ${ }^{32}$

Knowing the exact underlying genetic cause of the disease in an individual BCNS patient is important for providing adequate genetic counselling. It is important to diagnose BCNS at an early age, so an adequate screening program can be established and information about sun-protective behaviour can be provided to limit the burden of BCCs. The development of numerous BCCs is a major problem in patients with BCNS. The number of BCCs varies between BCNS patients, with a 
mean lifetime number of tumours of more than 250.33 Most tumours are easy to treat with surgery or non-invasive therapy. However, treatment can be difficult and has significant psychological impact. ${ }^{34}$ Radiotherapy is contraindicated because it induces new skin tumours.

Table 1. Diagnostic criteria for basal cell naevus syndrome (Bree et $a .^{20}$ ). Two major criteria, one major criterion and two minor criteria, or one major and genetic confirmation are required for diagnosis.

\begin{tabular}{ll}
\hline Major criteria & Minor criteria \\
\hline $\begin{array}{l}\text { Multiple BCCs or one BCC in a person younger } \\
\text { than } 20 \text { years }\end{array}$ & Bifid, fused or splayed ribs \\
\hline Odontogenic keratocysts & $\begin{array}{l}\text { Other specific skeletal and radiologic abnormalities } \\
\text { (i.e. pectus excavatum, scoliosis, hemivertebrae, } \\
\end{array}$ \\
$\begin{array}{ll}\text { Sprengel's deformity, syndactyly of digits, bony } \\
\text { bridging of the sella turcica, flame-shaped } \\
\text { lucencies of phalanges) }\end{array}$ \\
\hline Palmar or plantar pits & Macrocephaly \\
\hline Lamellar calcification of the falx cerebri & Cleft lip or palate \\
\hline First-degree relative with BCNS & Ovarian or cardiac fibroma \\
\hline & Lymphomesenteric cysts \\
\hline
\end{tabular}




\section{Cutaneous mosaicism}

A mosaic refers to a composite of different materials, for example a design made by putting together differently coloured pieces of stone. A mosaic organism is composed of two or more genetically distinct cell populations, derived from a genetically homogeneous zygote. ${ }^{35}$ In the animal and plant kingdom there are several examples of mosaicism (Figure 1.3). In fact all female individuals are mosaics because of lionisation (inactivation) of the X-chromosome. In dermatology, mosaicism is a common phenomenon as well. Patterns of mosaicism can be easily studied on the skin because it is accessible to visual examination. In 1901 dermatologist Alfred Blaschko first described different linear patterns in epidermal and sebaceous nevi. ${ }^{36}$ This system of lines, in which cells divide along prerequisite patterns during embryogenesis, is now referred to as Blaschko lines (Figure 1.4) ) $^{36,37}$. Mosaic skin diseases may follow Blaschko lines, but additional patterns of cutaneous mosaicism have been described by dermatologist Rudolph Happle (Figure 1.5). ${ }^{35}$

Several autosomal dominant disorders manifest themselves in mosaic patterns on the skin. Type 1 segmental mosaicism refers to the situation in which a de novo postzygotic mutation occurs somewhere during embryogenesis, only affecting cells from the mutant progenitor, resulting in mixed healthy and affected cell populations. Depending on the mutation load and the tissues involved, an individual with postzygotic mosaicism may develop clinical signs to a certain degree or none at all. Gonadal cells can also be affected in type 1 segmental mosaicism, meaning that an individual with this condition can give birth to a child with a germline mutation. Type 2 segmental mosaicism refers to an autosomal dominant disorder which is accompanied by a postzygotic mutation that affects the healthy allele, resulting in pronounced cutaneous symptoms of the disease in a mosaic pattern (Figure 1.6). ${ }^{38}$

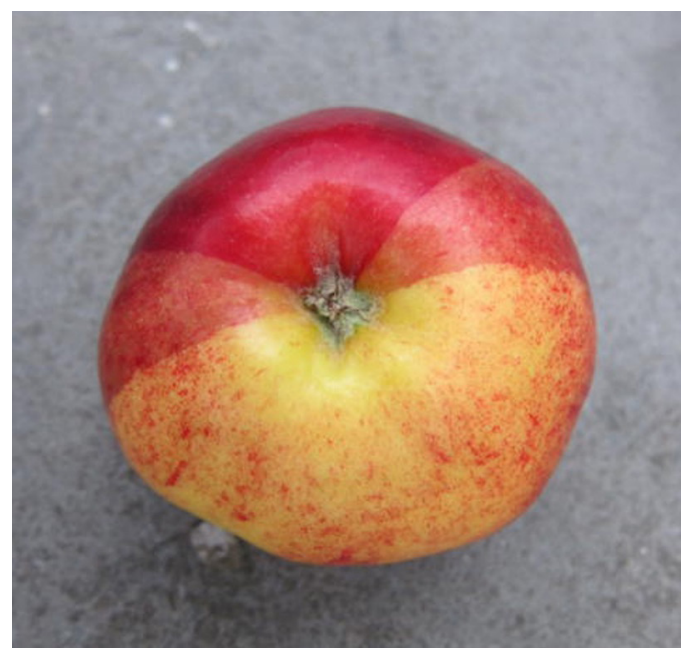

Figure 1.3. Mosaicism in an apple (picture provided by the Dutch Fruit Growers Organisation). 
Chapter 1

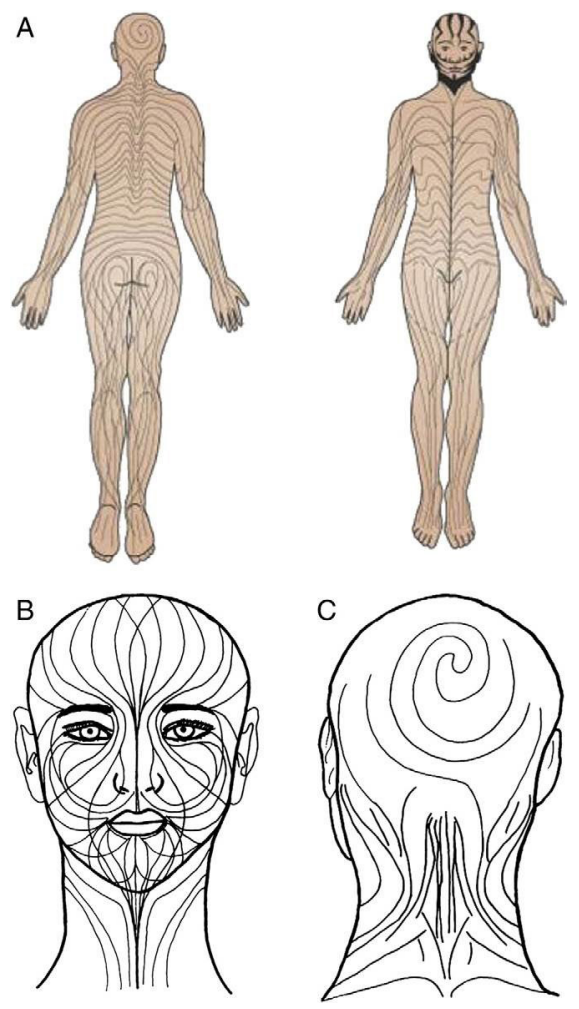

Figure 1.4. Lines of Blaschko. ${ }^{37}$

16 


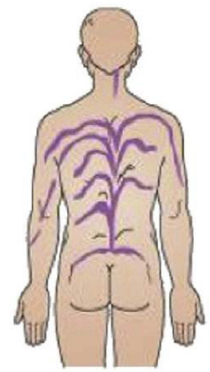

Type 1a

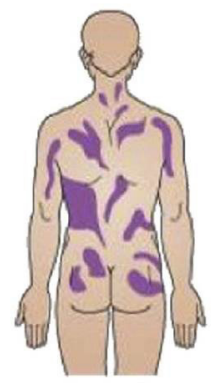

Type 3

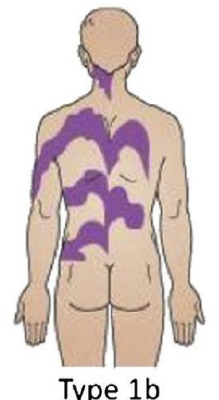

Type $1 b$

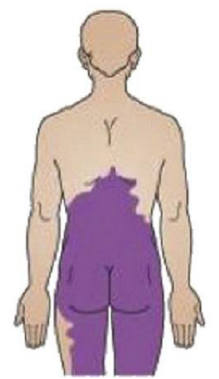

Type 4
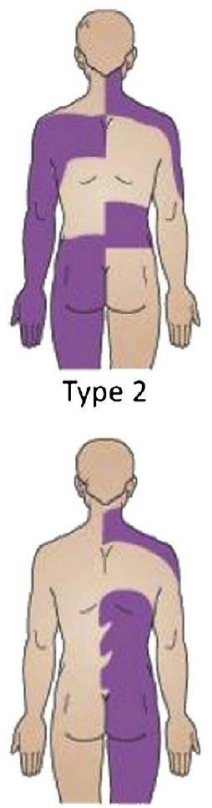

Type 5

Figure 1.5. Patterns of cutaneous mosaicism according to dr. R. Happle. ${ }^{35}$

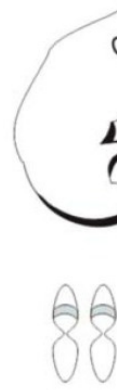

Normal
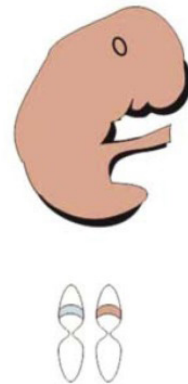

Heterozygotic (Abnormal)
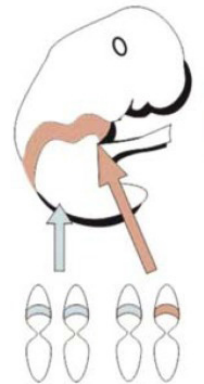

Type 1 segmental mosaicism
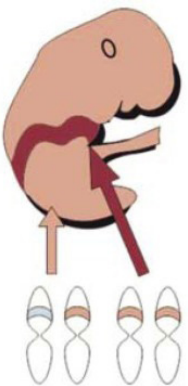

Type 2 segmental mosaicism (loss of heterozygocity)

Figure 1.6. Postzygotic mosaicism in autosomal dominant disorders. ${ }^{38}$ 


\section{Hedgehog pathway inhibitors}

In the 1950s sheep ranchers in the western United States experienced episodic outbreaks of one-eyed lambs. It turned out that ewes that grazed on corn lily (Veratrum californicum) during a certain period of their pregnancy gave birth to lambs with midline defects, like cyclopia and a proboscis-like nasal structure. In 1968 the responsible substance for these birth defects was isolated from the plant and named cyclopamine. ${ }^{39}$ In 1978 the Hh signalling pathway was discovered in the fruit fly (Drosophila melanogaster). Inactivation of this pathway caused the Drosophila larvae to be covered with spiny dendricles, resembling a hedgehog, hence its name. Mouse embryos lacking Sonic hedgehog gene function develop congenital abnormalities in the brain and spinal cord, axial skeleton and the limbs, featuring holoprosencephaly (failure of the forebrain to develop into hemispheres) and cyclopia. ${ }^{40}$ Eventually it was found that loss of Hh signalling in human embryonic development can also result in holoprosencephaly. ${ }^{41,42}$ Because of the similarities between the cyclopamine induced developmental abnormalities in sheep and the clinical presentation of holoprosencephaly in humans, it was suggested that cyclopamine is capable of inhibiting the Hh pathway. ${ }^{43}$ Taipale et al. demonstrated in vitro in primary murine fibroblasts lacking functional PTCH (PTCH-/-) that cyclopamine inhibits the Hh pathway by antagonizing $\mathrm{SMO} .{ }^{44} \mathrm{Apart}$ from its role in embryonic development, the Hh pathway is activated in several forms of cancer, including BCC. Eventually, synthetic cyclopamine-like $\mathrm{SMO}$ antagonists, so called Hh inhibitors, have been developed as a targeted cancer treatment. In 2009 the results of a phase 1 trial to assess the safety and efficacy of Hh pathway inhibitor vismodegib in the treatment of locally advanced and metastatic BCC were published, followed by phase 2 trials. ${ }^{45,46}$ In 2012, the FDA registered the Hh inhibitor vismodegib for the treatment of metastasised and locally advanced BCC ineligible for surgery or radiotherapy. ${ }^{47}$ In 2014 vismodegib was approved in the Netherlands for this indication. Only few patients with BCC are eligible for treatment with Hh inhibitors. In 2015, 25 patients were treated with vismodegib in the Netherlands. Treatment with vismodegib is effective in the majority of patients. However, side effects are often a reason for discontinuation of the therapy and the development of tumour resistance is a major problem. ${ }^{48}$ Some patients with BCNS benefit from maintenance treatment with Hh inhibitors. However, treatment is still off-label and discontinuation of treatment because of side effects is even more common in this group of patients. ${ }^{49,50}$ 


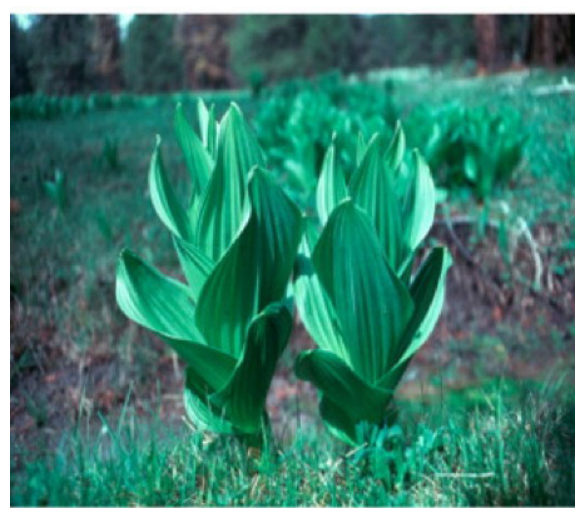

Figure 1.7. Corn lily (Veratrum californicum). ${ }^{39}$

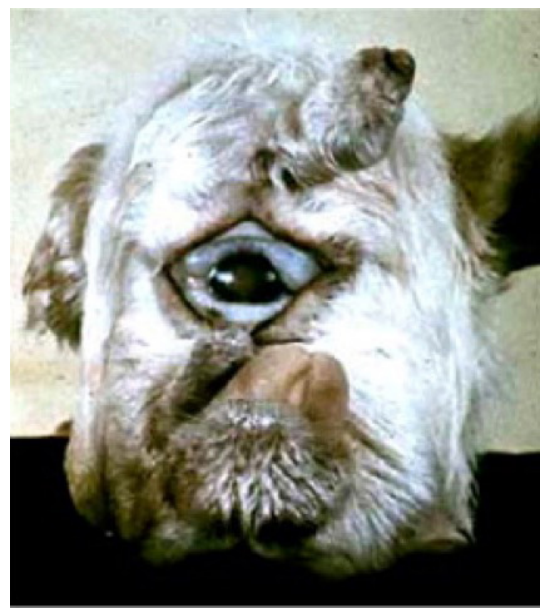

Figure 1.8. Cyclopic lamb fed Veratrum californicum on day 14 of gestation. ${ }^{39}$ 


\section{Aims of this thesis}

1. To create a database of all PTCH1 mutations detected in the Netherlands.

2. To learn more about the clinical and genetic characteristics in patients with BCNS, to eventually improve patient customized health care.

3. To understand mechanisms of resistance to hedgehog inhibitors in BCC.

4. To share experiences of treatment of locally advanced and metastasised basal cell carcinoma with vismodegib. 


\section{Outline of this thesis \\ Part one}

\section{Basal cell naevus syndrome}

In chapter 2 we established a locus-specific database for the PTCH1 gene using the Leiden Open Variation Database (LOVD). We gathered 111 mutations from 142 patients in whom PTCH1 mutation analysis was performed in either the VU University Medical Centre (VUMC) or the Maastricht University Medical Centre (MUMC) between 1995 and 2015. All these mutations were included in this public database together with previously published mutations worldwide.

In chapter $\mathbf{3}$ we describe the clinical characteristics of patients who carry a PTCH1 mutation. We looked for a genotype-phenotype correlation in our population and provided a review of the literature on this topic.

In chapter 4 we present a patient with BCNS caused by low grade postzygotic mosaicism of a PTCH1 mutation. Low grade mosaicism is not always detectable with standard genetic tests but has important implications for preventive measures and genetic counselling.

In chapter 5 we describe two patients with mosaic BCNS and no PTCH1 mutation in blood. Genetic analysis of their BCCs led to detection of postzygotic PTCH1 mosaicism. 


\section{Part two}

\section{Treatment of locally advanced and metastasised basal cell carcinoma with vismodegib}

In chapter $\mathbf{6}$ we describe the first Dutch patient treated with vismodegib for BCC. An overview of vismodegib treatment for BCC is given in chapter 7. Three different patient cases from three academic hospitals are presented. Indications, efficacy, adverse events and future perspectives of vismodegib are discussed. Our goal was to inform dermatologists, general practitioners, and other specialities about this new treatment modality for locally advanced and metastasised BCC.

In chapter $\mathbf{8}$ we describe a patient with locally advanced BCC who develops resistance to vismodegib after a complete clinical response. We performed mutational analysis on primary tumour tissue and resistant tumour tissue to explain the mechanism of development of drug resistance in this patient.

In chapter 9 we present a patient with locally advanced BCC who showed primary resistance to vismodegib together with the development of hyperkeratosis and epidermal cysts. This case illustrates how difficult the clinical assessment of tumour response can be and stresses the importance of repeated skin biopsies in the event of doubts. Furthermore, the development of epidermal cysts can give us information about the mechanism of action of hedgehog inhibitors.

Chapter 10 provides a summary, discussion and valorisation of this thesis, together with some future perspectives. In chapter 11 a Dutch summary of the thesis is given. 


\section{References}

1. McLean WH. Filaggrin failure - from ichthyosis vulgaris to atopic eczema and beyond. Br J Dermatol 2016;175 Suppl 2:4-7.

2. Hahn H, Wicking C, Zaphiropoulous PG, et al. Mutations of the human homolog of Drosophila patched in the nevoid basal cell carcinoma syndrome. Cell 1996;85:841-51.

3. Johnson RL, Rothman AL, Xie J, et al. Human homolog of patched, a candidate gene for the basal cell nevus syndrome. Science 1996;272:1668-71.

4. Flohil SC, Seubring I, van Rossum MM, Coebergh JW, de Vries E, Nijsten T. Trends in Basal cell carcinoma incidence rates: a 37-year Dutch observational study. J Invest Dermatol 2013;133:913-8.

5. Lomas A, Leonardi-Bee J, Bath-Hextall F. A systematic review of worldwide incidence of nonmelanoma skin cancer. Br J Dermatol 2012;166:1069-80.

6. Flohil SC, de Vries E, Neumann HA, Coebergh JW, Nijsten T. Incidence, prevalence and future trends of primary basal cell carcinoma in the Netherlands. Acta Derm Venereol 2011;91:24-30.

7. Flohil SC, Koljenovic S, de Haas ER, Overbeek LI, de Vries E, Nijsten T. Cumulative risks and rates of subsequent basal cell carcinomas in the Netherlands. Br J Dermatol 2011;165:874-81.

8. Jansen MHE, Mosterd K, Arits A, et al. Five-Year Results of a Randomized Controlled Trial Comparing Effectiveness of Photodynamic Therapy, Topical Imiquimod, and Topical 5-Fluorouracil in Patients with Superficial Basal Cell Carcinoma. J Invest Dermatol 2018;138:527-33.

9. Basal cell carcinoma. Dutch guideline: Dutch Society for Dermatology and Venereology (NVDV); 2015.

10. Walling HW, Fosko SW, Geraminejad PA, Whitaker DC, Arpey CJ. Aggressive basal cell carcinoma: presentation, pathogenesis, and management. Cancer Metastasis Rev 2004;23:389-402.

11. Wysong A, Aasi SZ, Tang JY. Update on metastatic basal cell carcinoma: a summary of published cases from 1981 through 2011. JAMA Dermatol 2013;149:615-6.

12. Tang S, Thompson S, Smee R. Metastatic basal cell carcinoma: case series and review of the literature. Australas J Dermatol 2017;58:e40-e3.

13. Epstein EH. Basal cell carcinomas: attack of the hedgehog. Nat Rev Cancer 2008;8:743-54.

14. Reifenberger J, Wolter M, Knobbe CB, et al. Somatic mutations in the PTCH, SMOH, SUFUH and TP53 genes in sporadic basal cell carcinomas. Br J Dermatol 2005;152:43-51.

15. BonillaX, Parmentier L, King B, et al. Genomic analysis identifies new drivers and progression pathways in skin basal cell carcinoma. Nat Genet 2016;48:398-406.

16. Evangelista M, Tian H, de Sauvage FJ. The hedgehog signaling pathway in cancer. Clin Cancer Res 2006;12:5924-8.

17. Gorlin RJ, Goltz RW. Multiple nevoid basal-cell epithelioma, jaw cysts and bifid rib. A syndrome. N Engl J Med 1960;262:908-12.

18. Kimonis VE, Goldstein AM, Pastakia B, et al. Clinical manifestations in 105 persons with nevoid basal cell carcinoma syndrome. Am J Med Genet 1997;69:299-308.

19. Evans DG, Farndon PA. Nevoid Basal Cell Carcinoma Syndrome. In: Pagon RA, Adam MP, Ardinger HH, et al., eds. GeneReviews(R). Seattle (WA)1993.

20. Bree AF, Shah MR, Group BC. Consensus statement from the first international colloquium on basal cell nevus syndrome (BCNS). Am J Med Genet A 2011;155A:2091-7.

21. Lo Muzio L. Nevoid basal cell carcinoma syndrome (Gorlin syndrome). Orphanet J Rare Dis 2008;3:32.

22. John AM, Schwartz RA. Basal cell naevus syndrome: an update on genetics and treatment. Br J Dermatol 2016;174:68-76. 
23. Aradhya $\mathrm{S}$, Lewis R, Bonaga $\mathrm{T}$, et al. Exon-level array CGH in a large clinical cohort demonstrates increased sensitivity of diagnostic testing for Mendelian disorders. Genet Med 2012;14:594-603.

24. Torrelo A, Hernandez-Martin A, Bueno E, et al. Molecular evidence of type 2 mosaicism in Gorlin syndrome. Br J Dermatol 2013;169:1342-5.

25. Fan Z, Li J, Du J, et al. A missense mutation in PTCH2 underlies dominantly inherited NBCCS in a Chinese family. J Med Genet 2008;45:303-8.

26. Fujii K, Ohashi H, Suzuki M, et al. Frameshift mutation in the PTCH2 gene can cause nevoid basal cell carcinoma syndrome. Fam Cancer 2013;12:611-4.

27. Smith MJ, Beetz C, Williams SG, et al. Germline mutations in SUFU cause Gorlin syndrome-associated childhood medulloblastoma and redefine the risk associated with PTCH1 mutations. J Clin Oncol 2014;32:4155-61.

28. Wicking C, Shanley S, Smyth I, et al. Most germ-line mutations in the nevoid basal cell carcinoma syndrome lead to a premature termination of the PATCHED protein, and no genotype-phenotype correlations are evident. Am J Hum Genet 1997;60:21-6.

29. Jones EA, Sajid MI, Shenton A, Evans DG. Basal cell carcinomas in gorlin syndrome: a review of 202 patients. J Skin Cancer 2011;2011:217378.

30. Evans DG, Oudit D, Smith MJ, et al. First evidence of genotype-phenotype correlations in Gorlin syndrome. J Med Genet 2017;54:530-6.

31. Knudson AG. Mutation and cancer: statistical study of retinoblastoma. Proceedings of the National Academy of Sciences 1971;68:820-3.

32. Chiang A, Jaju PD, Batra P, et al. Genomic Stability in Syndromic Basal Cell Carcinoma. J Invest Dermatol 2018;138:1044-51.

33. Solis DC, Kwon GP, Ransohoff KJ, et al. Risk Factors for Basal Cell Carcinoma Among Patients With Basal Cell Nevus Syndrome: Development of a Basal Cell Nevus Syndrome Patient Registry. JAMA Dermatol 2016.

34. van der Geer S, Ostertag JU, Krekels GA. Treatment of basal cell carcinomas in patients with nevoid basal cell carcinoma syndrome. J Eur Acad Dermatol Venereol 2009;23:308-13.

35. Happle R. Mosaicism in human skin. Understanding the patterns and mechanisms. Arch Dermatol 1993;129:1460-70.

36. Blaschko A. Die Nervenverteilung in der Haut in ihrer Beziezehung zu den Erkrankungen der Haut. Beilage zu den Verhandlungen der Deutschen Dermatologischen Gesellschaft VII Congress Breslau Braumuller, Wein 1901.

37. Happle R, Assim A. The lines of Blaschko on the head and neck. J Am Acad Dermatol 2001;44:612-5.

38. Kouzak SS, Mendes MS, Costa IM. Cutaneous mosaicisms: concepts, patterns and classifications. An Bras Dermatol 2013;88:507-17.

39. LeeST, Welch KD, Panter KE, Gardner DR, Garrossian M, Chang CW. Cyclopamine: from cyclops lambs to cancer treatment. J Agric Food Chem 2014;62:7355-62.

40. Chiang C, Litingtung Y, Lee E, et al. Cyclopia and defective axial patterning in mice lacking Sonic hedgehog gene function. Nature 1996;383:407-13.

41. Ming JE, Kaupas ME, Roessler E, et al. Mutations in patched-1, the receptor for sonic hedgehog, are associated with holoprosencephaly. Hum Genet 2002;110:297-301.

42. Nanni L, Ming JE, Bocian M, et al. The mutational spectrum of the sonic hedgehog gene in holoprosencephaly: SHH mutations cause a significant proportion of autosomal dominant holoprosencephaly. Hum Mol Genet 1999;8:2479-88.

43. Chen JK, Taipale J, Cooper MK, Beachy PA. Inhibition of Hedgehog signaling by direct binding of cyclopamine to Smoothened. Genes Dev 2002;16:2743-8. 
44. Taipale J, Chen JK, Cooper MK, et al. Effects of oncogenic mutations in Smoothened and Patched can be reversed by cyclopamine. Nature 2000;406:1005-9.

45. Sekulic A, Migden MR, Lewis $K$ et al. Pivotal ERIVANCE basal cell carcinoma (BCC) study: 12-month update of efficacy and safety of vismodegib in advanced BCC. J Am Acad Dermatol. 2015 Jun;72(6):1021-6.

46. Basset-Seguin N, Hauschild A, Kunstfeld R, et al. Vismodegib in patients with advanced basal cell carcinoma: Primary analysis of STEVIE, an international, open-label trial. Eur J Cancer 2017;86:33448.

47. Axelson M, Liu K, Jiang X, et al. U.S. Food and Drug Administration approval: vismodegib for recurrent, locally advanced, or metastatic basal cell carcinoma. Clin Cancer Res 2013;19:2289-93.

48. Basset-Seguin N, Hauschild A, Grob JJ, et al. Vismodegib in patients with advanced basal cell carcinoma (STEVIE): a pre-planned interim analysis of an international, open-label trial. Lancet Oncol 2015;16:729-36.

49. Chang AL, Arron ST, Migden MR, et al. Safety and efficacy of vismodegib in patients with basal cell carcinoma nevus syndrome: pooled analysis of two trials. Orphanet J Rare Dis 2016;11:120.

50. Tang JY, Ally MS, Chanana AM, et al. Inhibition of the hedgehog pathway in patients with basal-cell nevus syndrome: final results from the multicentre, randomised, double-blind, placebo-controlled, phase 2 trial. Lancet Oncol 2016;17:1720-31. 



\section{Part one}

Basal cell naevus syndrome 



\section{Chapter 2}

\section{New mutations and an updated database for the patched-1 (PTCH1) gene.}

M.G.H.C. Reinders*, A.F.W. van Hout*, B. Cosgun, A.D.C. Paulussen, E.M. Leter, P.M. Steijlen, K. Mosterd, M. van Geel, J.J.P. Gille

Molecular Genetics and Genomic Medicine, Mar 2018

*Both authors contributed equally to this paper and should be considered as first authors 


\section{Abstract}

Background Basal cell naevus syndrome is an autosomal dominant disorder characterized by multiple basal cell carcinomas, maxillary keratocysts and cerebral calcifications. BCNS most commonly is caused by a germline mutation in the patched-1 gene. PTCH1 mutations are also described in patients with holoprosencephaly.

Methods We have established a locus-specific database for the PTCH1 gene using the Leiden Open Variation Database (LOVD). We included 117 new PTCH1 variations, in addition to 331 previously published unique PTCH1 mutations. These new mutations were found in 141 patients who had a positive PTCH1 mutation analysis in either the VU University Medical Centre or Maastricht University Medical Centre between 1995 and 2015.

Results The database contains 331 previously published unique PTCH1 mutations and 117 new PTCH1 variations.

Conclusion We have established a locus-specific database for the PTCH1 gene using the Leiden Open Variation Database. The database provides an open collection for both clinicians and researchers and is accessible online at http://www.lovd.nl/PTCH1. 


\section{Introduction}

Basal cell naevus syndrome (BCNS, MIM\#109400) or Gorlin syndrome is a rare autosomal dominant disorder characterized by multiple basal cell carcinomas (BCCs), maxillary keratocysts and cerebral calcifications. ${ }^{1}$ The incidence of BCNS is estimated at 1 in 50,000 to 256,000. ${ }^{2}$ Diagnostic criteria for BCNS were first established by Evans et al. ${ }^{3}$, modified by Kimonis et al ${ }^{4}$. and revised in 2011 by Bree at al. ${ }^{5}$ Diagnosis is based on two major criteria, one major criterion and two minor criteria or one major criterion and genetic confirmation (Table 1).

Most frequently occurring symptoms are multiple BCCs, maxillary keratocysts, palmoplantar pits and calcification of the falx cerebri. About $60 \%$ of patients have a typical phenotype with macrocephaly, frontal bossing, coarse facial features and hypertelorism.3.4 3-5\% of patients develop medulloblastoma in childhood. ${ }^{6}$

In 1996 the patched-1 (PTCH1) gene (MIM\#601309) was first reported as a candidate gene for BCNS. Two different heterozygous mutations in the PTCH1 gene were identified in two patients with Gorlin syndrome. ${ }^{7}$ Another disorder that is caused by a germline mutation in the PTCH1 gene is holoprosencephaly-7 (MIM\#610828), a structural anomaly of the brain in which there is failed or incomplete separation of the forebrain early in gestation. In addition, the vast majority of sporadic BCCs have somatic mutations in PTCH1.,9

Table 1. Diagnostic criteria for basal cell naevus syndrome (Bree et al.5). Two major criteria, one major criterion and two minor criteria, or one major and genetic confirmation are required for diagnosis.

\begin{tabular}{|c|c|}
\hline Major criteria & Minor criteria \\
\hline $\begin{array}{l}\text { Multiple BCCs or one BCC in a person younger } \\
\text { than } 20 \text { years }\end{array}$ & Bifid, fused or splayed ribs \\
\hline Odontogenic keratocysts & $\begin{array}{l}\text { Other specific skeletal and radiologic abnormalities } \\
\text { (i.e. pectus excavatum, scoliosis, hemivertebrae, } \\
\text { Sprengel's deformity, syndactyly of digits, bony } \\
\text { bridging of the sella turcica, flame-shaped } \\
\text { lucencies of phalanges) }\end{array}$ \\
\hline Palmar or plantar pits & Macrocephaly \\
\hline Lamellar calcification of the falx cerebri & Cleft lip or palate \\
\hline Medulloblastoma in early childhood & Ovarian or cardiac fibroma \\
\hline \multirow[t]{2}{*}{ First-degree relative with BCNS } & Lymphomesenteric cysts \\
\hline & $\begin{array}{l}\text { Ocular anomalies (i.e. congenital cataract, } \\
\text { coloboma, glaucoma, hypertelorism) }\end{array}$ \\
\hline
\end{tabular}




\section{The PTCH1 gene}

PTCH1 (NCBI Reference Sequence NM_000264.3) is the human homolog of the Drosophila patched-1 gene and is located on chromosome 9q22.3. It contains 24 exons with the transcriptional start site in exon 1 and the termination site in exon 23. PTCH1 encodes a 1447amino acid transmembrane glyco-protein, which is part of the hedgehog ( $\mathrm{Hh}$ ) pathway. The Hh pathway is a key regulator in embryonic development and tumorigenesis controlling cell differentiation, tissue polarity and cell proliferation.

The function of the PTCH1 protein is inhibition of the transmembrane protein smoothened (SMO). Extracellular Hh ligands can bind to the PTCH1 receptor, releasing this inhibition, allowing SMO to signal downstream and activate GLI transcription factors. Based on this role in preventing cells from uncontrolled proliferation, $\mathrm{PTCH} 1$ is seen as a tumour suppressor gene. SMO on the other hand acts as an oncogene..$^{10}$

The typical congenital features of BCNS seem to occur due to haploinsufficiency, ${ }^{11}$ while tumours in BCNS are believed to develop according to the two-hit hypothesis described by Knudson. ${ }^{12,13}$ In the latter either both alleles of the gene harbour a mutation, or one mutated allele is accompanied by allelic loss of the remaining wild type allele. Recent mouse model studies show that haploinsufficiency of PTCH1 may be sufficient for the development of medulloblastoma and rhabdomyosarcoma, so tumour formation not always follows the two-hit hypothesis. ${ }^{14,15}$ With DNA sequencing analysis of the PTCH1 gene, mutation detection frequency ranges from $50 \%$ to $85 \%$ in individuals with typical findings of BCNS. ${ }^{16}$ Mosaic presentations of BCNS can occur. ${ }^{17,18}$

\section{The PTCH1 database}

We have established a database for PTCH1 using the Leiden Open Variation Database (LOVD) version 3.0. ${ }^{19}$ The purpose of this database is to assemble molecular variants of the PTCH1 gene in a standardized format. The database provides an open collection for both clinicians and researchers containing published and unpublished PTCH1 mutations.

For each mutation, information is provided at the molecular level: DNA change, predicted protein change, RNA change, exon, type of mutation, reported pathogenicity, technique used and source of material, and phenotype information if available. The Sequence Variant Nomenclature of all mutations (new and published) is updated according to the latest guidelines of the Human Genome Variation Society (HGVS) version 15.11 and based on NCBI Reference Sequence NM_000264.3. 


\section{Analysis of the database}

The database lists 331 previously published unique PTCH1 mutations. ${ }^{19}$ In addition, we included 117 new PTCH1 variations (Table 2). These mutations were found in 141 patients who had a positive PTCH1 mutation analysis in either the VU University Medical Centre (VUMC) or Maastricht University Medical Centre (MUMC) between 1995 and 2015. Mutation analysis was performed using Sanger sequencing and Multiplex Ligation-dependent Probe Amplification. Polymorphisms and patients from the same family were excluded. Of the 117 different PTCH1 variations, 110 mutations are classified as pathogenic or probably pathogenic according to the guidelines of the Associations for Clinical Genetic Science and the Dutch Society of Clinical Genetic laboratory Specialists and the American College of Medical Genetics and Genomics (ACMG). ${ }^{21,22} \mathrm{~A}$ number of 23 PTCH1 mutations are reported by previous studies and 79 are novel.

Of the 110 new mutations 38\% (42/110) are frameshift (33 small deletions, 8 small duplications, 1 small indel), 26\% (29/110) nonsense, 13\% (14/110) missense and 15\% (16/110) are splicing mutations. The remaining 8\% (9/110) are large genomic PTCH1 deletions and duplications. The mutations were found in all coding exons (1-23) and no hotspot was found.

The majority of patients were from the Netherlands (68\%, 76/110). The age of DNA test ranged from $0-70$ years, with a mean age of 26.5 years. Motivations for genetic testing written on the application forms were: 1) clinical suspicion of BCNS (47.4\%); 2) clinical diagnosis of BCNS (32.6\%); 3) first degree family member with BCNS (16.8\%); and 4) family members with symptoms of BCNS (3.2\%). In total four individuals were prenatally screened for BCNS, because of a first-degree family member or a clinical suspicion based on ultrasonography.

\section{Database availability}

The data is accessible to the public at http://www.lovd.nl/PTCH1. Contributors will have to register for a login and password. 
TABLE 2 New PTCH1 mutations

\begin{tabular}{|c|c|c|c|c|c|c|c|c|}
\hline $\begin{array}{l}\text { Case } \\
\text { identifier }\end{array}$ & $\begin{array}{l}\text { Members } \\
\text { affected }\end{array}$ & Gender & $\begin{array}{l}\text { Age of } \\
\text { diagnosis }\end{array}$ & $\begin{array}{l}\text { Exon/ } \\
\text { Intron }\end{array}$ & DNA variant & Protein change & $\begin{array}{l}\text { RNA } \\
\text { change }\end{array}$ & Classification \\
\hline \multicolumn{9}{|c|}{ Nonsense mutations } \\
\hline BCNS1 & 1 & M & 67.7 & 2 & c. $205 \mathrm{~A}>\mathrm{T}$ & p.(Lys69*) & r.(?) & 5 \\
\hline BCNS2 & 1 & $\mathrm{~F}$ & 24.4 & 2 & c. $279 \mathrm{C}>\mathrm{G}$ & p. $\left(\mathrm{Tyr} 93^{*}\right)$ & r.(?) & 5 \\
\hline $\mathrm{BCNS} 3$ & 1 & $\mathrm{~F}$ & 27.9 & 2 & c. $294 \mathrm{C}>\mathrm{A}$ & p. $\left(\right.$ Cys $\left.98^{*}\right)$ & r.(?) & 5 \\
\hline BCNS4 & 2 & M & 38.9 & 3 & c. $403 \mathrm{C}>\mathrm{T}$ & p. $\left(\operatorname{Arg} 135^{*}\right)$ & r.(?) & 5 \\
\hline BCNS5 & 3 & $\mathrm{~F}$ & 26.1 & 3 & c. $403 \mathrm{C}>\mathrm{T}$ & p. $\left(\operatorname{Arg} 135^{*}\right)$ & r.(?) & 5 \\
\hline BCNS6 & 3 & M & 11.0 & 3 & c. $466 \mathrm{C}>\mathrm{T}$ & p.(Gln $156 *)$ & r.(?) & 5 \\
\hline BCNS7 & 1 & M & 14.1 & 5 & c. $707 \mathrm{G}>\mathrm{A}$ & p. $\left(\operatorname{Trp} 236^{*}\right)$ & r.(?) & 5 \\
\hline BCNS8 & 2 & $\mathrm{U}$ & 56.6 & 8 & c. $1081 \mathrm{C}>\mathrm{T}$ & p. $\left(\mathrm{G} \ln 361^{*}\right)$ & r.(?) & 5 \\
\hline BCNS9 & 1 & $\mathrm{~F}$ & 36.7 & 8 & c. $1093 \mathrm{C}>\mathrm{T}$ & p. $\left(\mathrm{G} \ln 365^{*}\right)$ & r.(?) & 5 \\
\hline BCNS10 & 1 & M & 8.4 & 8 & c. $1119 \mathrm{C}>\mathrm{G}$ & p. $($ Tyr373*) & r.(?) & 5 \\
\hline BCNS11 & 1 & $\mathrm{~F}$ & 1.1 & 8 & c. $1198 \mathrm{C}>\mathrm{T}$ & p. $(\mathrm{G} \ln 400 *)$ & r.(?) & 5 \\
\hline BCNS12 & 1 & $\mathrm{~F}$ & 8.3 & 10 & c. $1379 \mathrm{G}>\mathrm{A}$ & p. $\left(\operatorname{Trp} 460^{*}\right)$ & r.(?) & 5 \\
\hline BCNS13 & 2 & $\mathrm{U}$ & 31.0 & 10 & c. $1380 \mathrm{G}>\mathrm{A}$ & p. $\left(\operatorname{Trp} 460^{*}\right)$ & r.(?) & 5 \\
\hline BCNS14 & 1 & M & 0.0 & 12 & c. $1691 \mathrm{~T}>\mathrm{G}$ & p.(Leu564*) & r.(?) & 5 \\
\hline BCNS15 & 1 & M & 31.1 & 13 & c. $1804 \mathrm{C}>\mathrm{T}$ & p. $(\operatorname{Arg} 602 *)$ & r.(?) & 5 \\
\hline BCNS16 & $\begin{array}{l}1, \\
\text { mosaicism }\end{array}$ & $\mathrm{F}$ & 23.0 & 13 & c. $1810 \mathrm{G}>\mathrm{T}$ & p.(Glu604*) & r.(?) & 5 \\
\hline BCNS17 & 1 & $\mathrm{~F}$ & 33.0 & 14 & c. $1975 \mathrm{C}>\mathrm{T}$ & p. $(\mathrm{G} \ln 659 *)$ & r.(?) & 5 \\
\hline BCNS18 & 2 & F & 24.4 & 14 & c. $2098 \mathrm{C}>\mathrm{T}$ & p. $\left(\mathrm{G} \ln 700^{*}\right)$ & r.(?) & 5 \\
\hline BCNS19 & 1 & $\mathrm{~F}$ & 25.1 & 14 & c. $2170 \mathrm{G}>\mathrm{T}$ & p.(Glu724*) & г.(?) & 5 \\
\hline BCNS20 & 2 & $\mathrm{~F}$ & 56.7 & 15 & c. $2308 \mathrm{C}>\mathrm{T}$ & p. $(\operatorname{Arg} 770 *)$ & r.(?) & 5 \\
\hline BCNS21 & 1 & M & 42.4 & 15 & c. $2359 \mathrm{G}>\mathrm{T}$ & p. $($ Glu787*) & r.(?) & 5 \\
\hline BCNS22 & 1 & $\mathrm{~F}$ & 11.5 & 15 & c. $2446 \mathrm{C}>\mathrm{T}$ & p. $\left(\mathrm{G} \ln 816^{*}\right)$ & r.(?) & 5 \\
\hline BCNS23 & 1 & M & 19.7 & 15 & c. $2557 \mathrm{C}>\mathrm{T}$ & p. $\left(\mathrm{G} \ln 853^{*}\right)$ & r.(?) & 5 \\
\hline BCNS24 & 1 & M & 4.3 & 16 & c. $2619 \mathrm{C}>\mathrm{A}$ & p.(Tyr873*) & r. $(?)$ & 5 \\
\hline BCNS25 & 1 & M & 25.8 & 16 & c. $2619 \mathrm{C}>\mathrm{A}$ & p. $($ Tyr873*) & г.(?) & 5 \\
\hline BCNS26 & 1 & M & 14.1 & 16 & c. $2619 \mathrm{C}>\mathrm{G}$ & p.(Tyr873*) & r.(?) & 5 \\
\hline BCNS27 & 1 & $\mathrm{~F}$ & 6.2 & 18 & c. $3027 \mathrm{C}>\mathrm{A}$ & p. $($ Tyr1009*) & r.(?) & 5 \\
\hline BCNS28 & 2 & $\mathrm{~F}$ & 47.9 & 18 & c. $3027 \mathrm{C}>\mathrm{G}$ & p. $($ Tyr1009*) & r.(?) & 5 \\
\hline BCNS29 & 1 , de novo & $\mathrm{F}$ & 14.1 & 18 & c. $3058 \mathrm{C}>\mathrm{T}$ & p. $\left(\mathrm{G} \ln 1020^{*}\right)$ & r.(?) & 5 \\
\hline \multicolumn{9}{|c|}{ Missense mutations } \\
\hline BCNS30 & 1 , de novo & $\mathrm{F}$ & 28.8 & 4 & c. $591 \mathrm{G}>\mathrm{C}$ & p.(Trp197Cys) & r.(?) & 5 \\
\hline BCNS31 & 1 & M & 11.7 & 5 & c. $689 \mathrm{C}>\mathrm{G}$ & p.(Thr230Arg) & r.(?) & 4 \\
\hline BCNS32 & 1 & M & 31.1 & 6 & c. $890 \mathrm{~T}>\mathrm{C}$ & p.(Leu297Pro) & r.(?) & 4 \\
\hline BCNS33 & 2 & M & 7.4 & 10 & c. $1439 \mathrm{C}>\mathrm{T}$ & p.(Ser480Leu) & r.(?) & 4 \\
\hline BCNS34 & 1 & M & & 10 & c. $1450 \mathrm{G}>\mathrm{A}$ & p.(Gly484Arg) & r.(?) & 4 \\
\hline BCNS35 & 1 & M & 36.9 & 11 & c. $1526 \mathrm{G}>\mathrm{A}$ & p.(Gly509Asp) & r.(?) & 5 \\
\hline BCNS36 & 1 & M & 58.4 & 11 & c. $1526 \mathrm{G}>\mathrm{A}$ & p.(Gly509Asp) & r.(?) & 5 \\
\hline BCNS37 & 3 & M & 15.1 & 11 & c. $1526 \mathrm{G}>\mathrm{A}$ & p.(Gly509Asp) & r.(?) & 5 \\
\hline BCNS38 & 1 & $\mathrm{~F}$ & 40.3 & 11 & c. $1555 \mathrm{G}>\mathrm{C}$ & p.(Ala519Pro) & r.(?) & 4 \\
\hline BCNS39 & 1 & $\mathrm{U}$ & 39.2 & 12 & c. $1712 \mathrm{G}>\mathrm{C}$ & p.(Arg571Pro) & r.(?) & 4 \\
\hline
\end{tabular}


T A B L E 2 (Continued)

\begin{tabular}{|c|c|c|c|c|c|c|c|c|}
\hline $\begin{array}{l}\text { Case } \\
\text { identifier }\end{array}$ & $\begin{array}{l}\text { Members } \\
\text { affected }\end{array}$ & Gender & $\begin{array}{l}\text { Age of } \\
\text { diagnosis }\end{array}$ & $\begin{array}{l}\text { Exon/ } \\
\text { Intron }\end{array}$ & DNA variant & Protein change & $\begin{array}{l}\text { RNA } \\
\text { change }\end{array}$ & Classification \\
\hline BCNS40 & 1 & M & 38.9 & 14 & c. $2250 \mathrm{G}>\mathrm{C}$ & p.(Lys750Asn) & r.spl? & 4 \\
\hline BCNS41 & 1 & M & 46.7 & 15 & c. $2414 \mathrm{~T}>\mathrm{G}$ & p.(Ile805Arg) & r.(?) & 4 \\
\hline BCNS42 & 1 & M & 22.6 & 15 & c. $2447 \mathrm{~A}>\mathrm{G}$ & p.(Gln816Arg) & r.(?) & 4 \\
\hline BCNS43 & 1 & $\mathrm{~F}$ & 52.1 & 18 & c. $2917 \mathrm{C}>\mathrm{A}$ & p.(Gln973Lys) & r.(?) & 4 \\
\hline \multicolumn{9}{|c|}{ Splice site mutations } \\
\hline BCNS44 & 1 & $\mathrm{~F}$ & 17.1 & $1 \mathrm{i}$ & c. $202-2 \mathrm{~A}>\mathrm{G}$ & p.? & r.spl? & 4 \\
\hline BCNS45 & 2 & $\mathrm{~F}$ & 23.5 & $2 \mathrm{i}$ & c. $394+1 G>A$ & p.? & r.spl? & 4 \\
\hline BCNS46 & 2 & M & 17.7 & $2 \mathrm{i}$ & c. $394+1 \mathrm{G}>\mathrm{C}$ & p.? & r.spl? & 4 \\
\hline BCNS47 & 1 & $\mathrm{~F}$ & 13.6 & $4 \mathrm{i}$ & c. $566 \_584+8 \mathrm{del}$ & p.? & r.spl? & 4 \\
\hline BCNS48 & 1 & M & 12.3 & $4 \mathrm{i}$ & c. $655-1 \mathrm{G}>\mathrm{A}$ & p.? & r.spl? & 4 \\
\hline BCNS49 & 1 & $\mathrm{~F}$ & 21.5 & $5 \mathrm{i}$ & c. $747-2 \mathrm{~A}>\mathrm{G}$ & p.? & r.spl? & 4 \\
\hline BCNS50 & 4 & M & 2.6 & $6 \mathrm{i}$ & c. $946-1 \mathrm{G}>\mathrm{T}$ & p.? & r.spl? & 4 \\
\hline BCNS51 & 2 & $\mathrm{~F}$ & 22.3 & $8 \mathrm{i}$ & c. $1216-2 \mathrm{~A}>\mathrm{G}$ & p.? & r.spl? & 4 \\
\hline BCNS52 & 2 & $\mathrm{~F}$ & 33.1 & $9 \mathrm{i}$ & c. $1347+1 \mathrm{G}>\mathrm{A}$ & p.? & r.spl? & 4 \\
\hline BCNS53 & 2 & M & 32.3 & $9 \mathrm{i}$ & c. $1348-1 \mathrm{G}>\mathrm{C}$ & p.? & r.spl? & 4 \\
\hline BCNS54 & 1 & M & 24.0 & $10 \mathrm{i}$ & c. $1504-1 \mathrm{G}>\mathrm{C}$ & p.? & r.spl? & 4 \\
\hline BCNS55 & 1 & M & 59.7 & $10 \mathrm{i}$ & c. $1504-2 \mathrm{~A}>\mathrm{T}$ & p.? & r.spl? & 4 \\
\hline BCNS56 & 2 & M & 27.1 & $12 \mathrm{i}$ & c. $1729-1 \mathrm{G}>\mathrm{C}$ & p.? & r.spl? & 5 \\
\hline BCNS57 & 1 & M & 69.4 & $14 \mathrm{i}$ & c. $2250+1 \mathrm{G}>\mathrm{T}$ & p.? & r.spl? & 4 \\
\hline BCNS58 & 1 & $\mathrm{~F}$ & 28.2 & $14 \mathrm{i}$ & c. $2251-2 \mathrm{~A}>\mathrm{G}$ & p.? & r.spl? & 4 \\
\hline BCNS59 & 1 & M & 7.1 & $15 \mathrm{i}$ & c. $2561-2 A>G$ & p.? & r.spl? & 4 \\
\hline \multicolumn{9}{|c|}{ Small deletions or duplications } \\
\hline BCNS60 & 1 , de novo & $\mathbf{M}$ & 5.4 & 1 & c.114del & p.(Leu39Cysfs*41) & r.(?) & 5 \\
\hline BCNS61 & 2 & M & 31.0 & 2 & c.254_255del & p.(Arg85Thrfs*4) & r.(?) & 5 \\
\hline BCNS62 & 1 & $\mathrm{~F}$ & 49.7 & 2 & c. $258 \_259$ del & p.(Leu87llefs*2) & r.(?) & 5 \\
\hline BCNS63 & 1 & M & 28.5 & 2 & c.258_259del & p.(Leu87llefs*2) & r.(?) & 5 \\
\hline BCNS64 & 1 & M & 52.0 & 2 & c.262_266del & p.(Phe88Thrfs*50) & r.(?) & 5 \\
\hline BCNS65 & 1 & $\mathbf{M}$ & 30.9 & 2 & c.385_386dup & p.(Trp129Cysfs*9) & r.(?) & 5 \\
\hline BCNS66 & 1 & M & 14.7 & 3 & c. $479 \_482$ del & p.(Gln160Profs*10) & r.(?) & 5 \\
\hline BCNS67 & 1 & $\mathbf{M}$ & 10.7 & 3 & c.572_575dup & p.(Met192Ilefs*61) & r.(?) & 5 \\
\hline BCNS68 & 1 & $\mathrm{~F}$ & 63.8 & 5 & c.724del & p.(Gln242Serfs*8) & r.(?) & 5 \\
\hline BCNS69 & 1 & $\mathrm{~F}$ & 25.8 & 6 & c.770_771delinsGGTTTGG & p.(Thr257Argfs*14) & r.(?) & 5 \\
\hline BCNS70 & 1 & $\mathrm{~F}$ & 43.8 & 6 & c.842del & p.(Met281fs*2) & r.(?) & 5 \\
\hline BCNS71 & 1 & $\mathrm{~F}$ & 11.4 & 7 & c.1040_1049del & p.(Val347Alafs*17) & r.(?) & 5 \\
\hline BCNS72 & 1 & $\mathrm{~F}$ & 35.1 & 8,14 & c. $[1114 \mathrm{del} ; 2183 \mathrm{C}>\mathrm{T}]$ & $\begin{array}{l}\text { p. }[(\text { Met372Cysfs*60); } \\
\text { p.(Thr728Met)] }\end{array}$ & r.(?) & $5 ; 3$ \\
\hline BCNS73 & 1 & $\mathrm{~F}$ & 23.9 & 9 & c.1279del & p.(Leu427Trpfs*5) & r.(?) & 5 \\
\hline BCNS74 & 1 & M & 35.1 & 10 & c.1348_1350del & p.(Leu450del) & r.(?) & 4 \\
\hline BCNS75 & 1 & $\mathbf{M}$ & 55.5 & 10 & c.1366dup & p.(Thr456Asnfs*41) & r.(?) & 5 \\
\hline BCNS76 & 2 & $\mathrm{~F}$ & 13.3 & 10 & c.1415_1429del & p.(Ala472_Leu476del) & r.(?) & 4 \\
\hline BCNS77 & 1 & M & 47.9 & 11 & c.1508dup & p.(Leu503fs*) & r.(?) & 5 \\
\hline BCNS78 & 1 & M & 2.7 & 13 & c.1767_1769del & p.(Leu590del) & r.(?) & 4 \\
\hline
\end{tabular}


T A B L E 2 (Continued)

\begin{tabular}{|c|c|c|c|c|c|c|c|c|}
\hline $\begin{array}{l}\text { Case } \\
\text { identifier }\end{array}$ & $\begin{array}{l}\text { Members } \\
\text { affected }\end{array}$ & Gender & $\begin{array}{l}\text { Age of } \\
\text { diagnosis }\end{array}$ & $\begin{array}{l}\text { Exon/ } \\
\text { Intron }\end{array}$ & DNA variant & Protein change & $\begin{array}{l}\text { RNA } \\
\text { change }\end{array}$ & Classification \\
\hline BCNS79 & 1 & $\mathrm{~F}$ & 8.3 & 14 & c. 1852 del & p.(Cys618Alafs*5) & r.(?) & 5 \\
\hline BCNS80 & 1 & M & 43.0 & 14 & c.1925dup & p.(Pro643Thrfs*11) & r.(?) & 5 \\
\hline BCNS81 & 1 & $\mathrm{~F}$ & 16.4 & 14 & c.2011dup & p.(His671Profs*10) & r.(?) & 5 \\
\hline BCNS82 & 1 & M & 15.5 & 14 & c. $2178 \_2179$ ins A & p.(Cys727Metfs*11) & r.(?) & 5 \\
\hline BCNS83 & 1 & M & 14.9 & 14 & c.2179del & p.(Cys727Valfs*19) & r.(?) & 5 \\
\hline BCNS84 & 1 & M & 42.2 & 16 & c. $2612 \_2615 \mathrm{del}$ & p.(Asn871Ilefs*31) & r.(?) & 5 \\
\hline BCNS85 & 1 & $\mathrm{~F}$ & 9.7 & 17 & c. $2748 \mathrm{del}$ & p.(Ser917Alafs*7) & r.(?) & 5 \\
\hline BCNS86 & 1 & $\mathrm{~F}$ & 1.2 & 17 & c. $2793 \mathrm{del}$ & p.(Val932Serfs*30) & r.(?) & 5 \\
\hline BCNS87 & 1 & $\mathrm{~F}$ & 14.5 & 17 & c.2833_2843del & p.(Arg945Glyfs*10) & r.(?) & 5 \\
\hline BCNS88 & 1 & M & 52.4 & 18 & c.3050del & p.(Phe1017Serfs*32) & r.(?) & 5 \\
\hline BCNS89 & 2 & M & 40.3 & 18 & c.3056_3059del & p.(Glu1019Glyfs*29) & r.(?) & 5 \\
\hline BCNS90 & 2 & $\mathrm{~F}$ & 21.0 & 18 & c.3107_3108del & p.(Leu1036Cysfs*108) & r.(?) & 5 \\
\hline BCNS91 & 3 & $\mathrm{~F}$ & 0.6 & 18,23 & c. $[3135 \mathrm{del} ; 4048 \mathrm{C}>\mathrm{T}]$ & $\begin{array}{l}\text { p.[(Phe1046Serfs*3; } \\
\text { (Arg1350Trp)] }\end{array}$ & r.(?) & $5 ; 3$ \\
\hline BCNS92 & 1 & M & 15.8 & 18 & c.3139_3142del & p.(Leu1047*) & r.(?) & 5 \\
\hline BCNS93 & 1 & M & 13.8 & 18 & c.3139del & p.(Leu1047fs*11) & r.(?) & 5 \\
\hline BCNS94 & 1 & $\mathrm{~F}$ & 23.1 & 18 & c.3150del & p.(Trp1051fs*7) & r.(?) & 5 \\
\hline BCNS95 & 1 & M & 33.2 & 19 & c.3233_3239del & p.(Leu1078Profs*7) & r.(?) & 5 \\
\hline BCNS96 & 1 & $\mathrm{U}$ & 9.3 & 19 & c.3251_3272del & p.(Val 1084Alafs*2) & r.(?) & 5 \\
\hline BCNS97 & 1 & M & 44.7 & 20 & c.3364_3365del & p.(Met1122Valfs*22) & r.(?) & 5 \\
\hline BCNS98 & 1 & M & 10.9 & 20 & c.3364_3365del & p.(Met1122Valfs*22) & r.(?) & 5 \\
\hline BCNS99 & 1 & $\mathrm{~F}$ & 54.4 & 20 & c. 3375 del & p.(Val1126Serfs*13) & r.(?) & 5 \\
\hline BCNS100 & 1 & $\mathrm{~F}$ & 41.8 & 21 & c.3497dup & p.(Asn1166Lysfs*18) & r.(?) & 5 \\
\hline BCNS101 & 1 & $\mathrm{U}$ & 6.7 & 21 & c.3525_3526del & p.(Leu1175Phefs*8) & r.(?) & 5 \\
\hline \multicolumn{9}{|c|}{ Large deletions or duplications } \\
\hline BCNS102 & 1 & $\mathrm{~F}$ & 48.5 & _1_24_ & c. $(?+-188) \_\left(* 3411 \_?\right)$ del & p. $0 ?$ & r. $0 ?$ & 5 \\
\hline BCNS103 & 1 & M & 47.2 & -1_24_ & c. $(?+-188) \_\left(* 3411 \_?\right)$ del & p.0? & r.0? & 5 \\
\hline BCNS104 & 1 & $\mathrm{~F}$ & 14.2 & -1_24_ & c. $(?-188) \_\left(* 3411 \_?\right)$ del & p. $0 ?$ & r. $0 ?$ & 5 \\
\hline BCNS105 & 1 & M & 36.6 & $-1 \_2 \mathrm{i}$ & $\begin{array}{l}\text { c. }(?-188) \_\left(394+1 \_395-1\right) \\
\text { del }\end{array}$ & p.? & r.(?) & 5 \\
\hline BCNS106 & 1 & $\mathrm{~F}$ & 38.0 & 2i_12i & $\begin{array}{l}\text { c. }\left(394+1 \_395-1\right) \_ \\
\left(1728+1 \_1729-1\right)(2)\end{array}$ & p.? & r.(?) & 4 \\
\hline BCNS107 & 1 , de novo & $\mathrm{F}$ & 14.9 & 2i_16i & $\begin{array}{l}\text { c. }\left(394+1 \_395-1\right) \_ \\
\left(2703+1 \_2704-1\right)(2)\end{array}$ & p.? & r.(?) & 4 \\
\hline BCNS108 & 1 & $\mathrm{~F}$ & 37.1 & $2 i_{-} 24_{-}$ & $\begin{array}{l}\text { c. }\left(394+1 \_395-1\right) \_ \\
\left(* 3411 \_?\right) \text { del }\end{array}$ & p.? & r.(?) & 5 \\
\hline BCNS109 & 1 & $\mathrm{~F}$ & 19.9 & 14i_16i & $\begin{array}{l}\text { c. }\left(2250+1 \_2251-1\right) \_ \\
\left(2703+1 \_2704-1\right) \text { del }\end{array}$ & p.? & r.(?) & 5 \\
\hline BCNS110 & 4 & M & 35.0 & 16i_19i & $\begin{array}{l}\text { c. }\left(2703+1 \_2704-1\right) \_ \\
\left(3306+1 \_3307-1\right) \mathrm{del}\end{array}$ & p.? & r.(?) & 5 \\
\hline \multicolumn{9}{|c|}{ Probably nonpathogenic } \\
\hline BCNS111 & 1 & $\mathrm{~F}$ & 27.3 & $7 \mathrm{i}$ & c. $1067+5 \mathrm{G}>\mathrm{C}$ & p.? & r.spl? & 2 \\
\hline BCNS112 & 1 & $\mathrm{~F}$ & 51.2 & 13 & c. $1792 \mathrm{~A}>\mathrm{T}$ & p.(Met598Leu) & r.(?) & 2 \\
\hline
\end{tabular}


TABLE 2 (Continued)

\begin{tabular}{|c|c|c|c|c|c|c|c|c|}
\hline $\begin{array}{l}\text { Case } \\
\text { identifier }\end{array}$ & $\begin{array}{l}\text { Members } \\
\text { affected }\end{array}$ & Gender & $\begin{array}{l}\text { Age of } \\
\text { diagnosis }\end{array}$ & $\begin{array}{l}\text { Exon/ } \\
\text { Intron }\end{array}$ & DNA variant & Protein change & $\begin{array}{l}\text { RNA } \\
\text { change }\end{array}$ & Classification \\
\hline BCNS113 & 1 & M & 70.3 & 14 & c. $2173 \mathrm{C}>\mathrm{T}$ & p.(Pro725Ser) & r.(?) & 2 \\
\hline BCNS114 & 1 & $\mathrm{~F}$ & 33.7 & 18 & c. $3155 \mathrm{C}>\mathrm{T}$ & p.(Thr1052Met) & r.(?) & 2 \\
\hline BCNS115 & 1 & M & 14.0 & 18 & c. $3155 \mathrm{C}>\mathrm{T}$ & p.(Thr1052Met) & r.(?) & 2 \\
\hline BCNS116 & 2 & $\mathrm{~F}$ & 43.3 & 18 & c. $3155 \mathrm{C}>\mathrm{T}$ & p.(Thr1052Met) & r.(?) & 2 \\
\hline BCNS117 & 2 & M & 29.9 & 21 & c. $3487 \mathrm{G}>\mathrm{A}$ & p.(Gly1163Ser) & r.(?) & 2 \\
\hline
\end{tabular}

NCBI Reference transcript PTCH1: NM_000264.3. All variants were detected in a heterozygous state (if two variants were present, they are presumed to be on the same allele, in trans). Variant nomenclature is according to HGVS guidelines. Classification is according to ACMG, ACGS, and VKGL criteria; class 5: pathogenic, class 4: likely pathogenic, class 3: uncertain significance, class 2: likely benign, class 1: benign. 


\section{References}

1. John AM, Schwartz RA. Basal cell naevus syndrome: an update on genetics and treatment. $\mathrm{Br} J$ Dermatol 2016;174:68-76.

2. Lo Muzio L. Nevoid basal cell carcinoma syndrome (Gorlin syndrome). Orphanet J Rare Dis 2008;3:32.

3. Evans DG, Ladusans EJ, Rimmer S, Burnell LD, Thakker N, Farndon PA. Complications of the naevoid basal cell carcinoma syndrome: results of a population based study. J Med Genet 1993;30:460-4.

4. Kimonis VE, Goldstein AM, Pastakia B, et al. Clinical manifestations in 105 persons with nevoid basal cell carcinoma syndrome. Am J Med Genet 1997;69:299-308.

5. Bree AF, Shah MR, Group BC. Consensus statement from the first international colloquium on basal cell nevus syndrome (BCNS). Am J Med Genet A 2011;155A:2091-7.

6. Evans DG, Farndon PA, Burnell LD, Gattamaneni HR, Birch JM. The incidence of Gorlin syndrome in 173 consecutive cases of medulloblastoma. Br J Cancer 1991;64:959-61.

7. Johnson RL, Rothman AL, Xie J, et al. Human homolog of patched, a candidate gene for the basal cell nevus syndrome. Science 1996;272:1668-71.

8. Bonilla X, Parmentier L, King B, et al. Genomic analysis identifies new drivers and progression pathways in skin basal cell carcinoma. Nat Genet 2016;48:398-406.

9. Reifenberger J, Wolter M, Knobbe CB, et al. Somatic mutations in the PTCH, SMOH, SUFUH and TP53 genes in sporadic basal cell carcinomas. Br J Dermatol 2005;152:43-51.

10. Kogerman P, Krause D, Rahnama F, et al. Alternative first exons of PTCH1 are differentially regulated in vivo and may confer different functions to the PTCH1 protein. Oncogene 2002;21:6007-16.

11. Wicking C, Shanley S, Smyth I, et al. Most germ-line mutations in the nevoid basal cell carcinoma syndrome lead to a premature termination of the PATCHED protein, and no genotype-phenotype correlations are evident. Am J Hum Genet 1997;60:21-6.

12. Knudson AG. Two genetic hits (more or less) to cancer. Nat Rev Cancer 2001;1:157-62.

13. Pan S, Dong Q, Sun LS, Li TJ. Mechanisms of inactivation of PTCH1 gene in nevoid basal cell carcinoma syndrome: modification of the two-hit hypothesis. Clin Cancer Res 2010;16:442-50.

14. Calzada-Wack J, Kappler R, Schnitzbauer U, et al. Unbalanced overexpression of the mutant allele in murine Patched mutants. Carcinogenesis 2002;23:727-33.

15. Zurawel RH, Allen C, Wechsler-Reya R, Scott MP, Raffel C. Evidence that haploinsufficiency of Ptch leads to medulloblastoma in mice. Genes Chromosomes Cancer 2000;28:77-81.

16. Lam C, Ou JC, Billingsley EM. "PTCH"-ing it together: a basal cell nevus syndrome review. Dermatol Surg 2013;39:1557-72.

17. Reinders MG, Boersma HJ, Leter EM, et al. Postzygotic mosaicism in basal cell naevus syndrome. Br J Dermatol 2016.

18. Torrelo A, Hernandez-Martin A, Bueno E, et al. Molecular evidence of type 2 mosaicism in Gorlin syndrome. Br J Dermatol 2013;169:1342-5.

19. Variants of patched 1 (PTCH1). Leiden University Medical Centre, 2004-2016. at http://databases. lovd.nl/shared/transcripts/00017082.)

20. http://www.lovd.nl/PTCH1.

21. Wallis Y PS, McAnulty C, Bodmer D, Sistermans E, Robertson K, Moore D, Abbs S, Deans Z, Devereau A. Practice guidelines for the evaluation of pathogenicity and the reporting of sequence variants in clinical molecular medicine. Association for Clinical Genetic Science (ACGS), Dutch Society of Clinical Laboratory Specialists (VKGL) 2013. 
22. Richards S, Aziz N, Bale S, et al. Standards and guidelines for the interpretation of sequence variants: a joint consensus recommendation of the American College of Medical Genetics and Genomics and the Association for Molecular Pathology. Genet Med 2015;17:405-24. 



\section{Chapter 3}

A genotype-phenotype study in basal cell naevus syndrome: a Dutch multicentre retrospective cohort study and review of the literature

B. Cosgun*, M.G.H.C. Reinders*, M. van Geel, P.M. Steijlen, A.F.W. van Hout, E.M. Leter, J.J. van der Smagt, J.M. van Hagen, L.P.V. Berger, C.M. Kets, A. Wagner, C.M. Aalfs, F.J. Hes, L.E. van der Kolk, J.J.P. Gille, K. Mosterd

Submitted for the Journal of the American Academy of Dermatology

*Both authors contributed equally to this paper and should be considered as first authors 


\section{Abstract}

Background Basal cell naevus syndrome is an autosomal dominant disorder most commonly caused by a germline mutation in the patched-1 (PTCH1) gene. It is characterized by multiple basal cell carcinomas, odontogenic keratocysts, palmoplantar pits and cerebral calcifications.

Objectives To assess whether there is a genotype-phenotype correlation in a Dutch population of patients with BCNS and to review the literature on this topic.

Methods All patients who had PTCH1 mutation analysis for diagnostic purposes in the Netherlands were recorded. Detailed clinical information from patients with a PTCH1 mutation was collected from their medical files. Subsequently, patients with germline mutations were assessed for BCNS diagnostic criteria described by Kimonis et al. and the revised criteria by Bree et al. A heat-map was created to enable visualization of a possible genotype-phenotype correlation.

Results In 141 of 673 (21.0\%) patients a pathogenic PTCH1 mutation was detected. Detailed clinical information could be obtained from 83 patients of whom, $95.2 \%$ and $96.4 \%$ fulfilled the old and revised diagnostic criteria for the diagnosis of BCNS, respectively. A heat map showed no correlation between the location or type of PTCH1 mutation and the presence of clinical symptoms.

Conclusion By using heat maps to demonstrate a genotype-phenotype correlation in our population of patients with BCNS, the earlier reported absence of a clear association was corroborated. 


\section{Introduction}

Basal cell naevus syndrome (BCNS), also known as Gorlin syndrome, is a rare autosomal dominant disorder (MIM\#109400). It was first described by Gorlin and Goltz in 1960. ${ }^{1}$ The estimated prevalence of BCNS reported in the literature is 1 in 56,000-256,000. ${ }^{2}$ Characteristic symptoms include basal cell carcinomas (BCCs), odontogenic keratocysts (OKCs), calcification of the falx cerebri, palmoplantar pits and skeletal malformations. ${ }^{2}$ The underlying cause is a heterozygous germline mutation in the patched-1 (PTCH1) gene, located on chromosome 9q22-31.3.4

The different symptoms that can be present in BCNS are explained by the dual function of the PTCH1 protein. By activating the hedgehog $(\mathrm{Hh})$-pathway, the PTCH1 protein has an important function in embryonic development. It regulates fate and patterning in the neural tube development and plays an important role in osteoblast differentiation. ${ }^{5}$ The various congenital malformations such as rib anomalies, macrocephaly and skeletal malformations, can be explained by this function and require only monoallelic inactivation of the PTCH1 gene to become manifest. ${ }^{6}$ The other important function of PTCH1 is its role as tumour suppressor in the Hh-signalling pathway. The pro-oncogenic Hh-pathway is involved in cell proliferation and differentiation, and PTCH1 inhibits activation of the pathway by repressing the activity of smoothened. However, a bi-allelic inactivated PTCH1 gene leads to development of tumours according to the two-hit hypothesis of Knudson.? Tumours, cysts, hamartomas and other described proliferations will only develop if a second hit in the normal remaining allele occurs (e.g. loss of heterozygosity). In BCNS this second hit occurs usually later in life resulting in BCCs, OKCs, medulloblastomas, ovarian fibromas and other less frequently occurring tumours. Mutations in other components of the Hh-pathway such as SUFU and PTCH2 have also been found to be responsible for the development of BCNS.8-11

Diagnostic criteria for BCNS were first proposed in 1993 by Evans et al. and modified by Kimonis et al. in 1997 (Table 1).12,13 BCNS mainly is a clinical diagnosis based on the presence of two major, or one major and two minor criteria. Additional mutation analysis can be used to confirm the diagnosis on a molecular level. The mutation detection rate of PTCH1 reported in the literature lies between 40 and 85\%.9.14-17 Bree et al. revised the diagnostic criteria in 2011 and integrated genetic test results, allowing to make this diagnosis with only one major criterion and the presence of a PTCH1 mutation (Table 2). Furthermore, medulloblastoma was designated as a major criterion instead of a minor, because of the relevance in early diagnosis. Although the overall incidence of medulloblastoma in BCNS is only 1-2\%, studies showed that $5-20 \%$ of all children that developed a medulloblastoma under the age of three had BCNS.18,19 Labelling medulloblastoma as an indicator for BCNS may therefore lead to earlier recognition of this syndrome. Further modifications of the diagnostic criteria, such as the switch of rib anomalies from a major to minor criterion and the addition of cardiac fibroma, lymphomesenteric cysts and ocular abnormalities to the minor criteria are shown in table 1 and 2. 
Previous studies have tried to demonstrate a genotype-phenotype correlation in BCNS. ${ }^{14,20-}$ 22 To date, no clear correlation was detected between clinical features of BCNS patients, the number of major symptoms, age of onset of BCCs and OKCs and the nucleotide position or type of PTCH1 mutation. In this study, we evaluated 83 Dutch patients with a confirmed PTCH1 mutation. We searched for possible genotype-phenotype correlations in this cohort and reviewed the literature on this topic.

Table 1. Diagnostic criteria for BCNS by Kimonis et al. ${ }^{13}$ Presence of two major, or one major and two minor criteria are required for diagnosis.

\begin{tabular}{ll}
\hline $\begin{array}{l}\text { Major criteria } \\
\text { >2 BCC S or one BCC in a person younger than 20 }\end{array}$ & Minor criteria \\
\hline Odontogenic keratocysts & $\begin{array}{l}\text { Congenital malformation (cleft lip/palate, frontal } \\
\text { bossing, coarse face, hypertelorism) }\end{array}$ \\
\hline${ }^{33}$ palmar or plantar pits & $\begin{array}{l}\text { Bridging of the sella turcica, vertebral anomalies, } \\
\text { modeling defects of the hands and feet, or flame- } \\
\text { shaped lucencies of the hands or feet }\end{array}$ \\
\hline Bilamellar calcification of the falx cerebri & $\begin{array}{l}\text { Other skeletal abnormalities (i.e. Sprengel } \\
\text { deformity, pectus deformity, marked syndactyly of }\end{array}$ \\
\hline Bifid, fused or splayed ribs & Ovarian fibroma \\
\hline First-degree relative with BCNS & Medulloblastoma \\
\hline
\end{tabular}

Table 2. Revised diagnostic criteria for BCNS by Bree et al. ${ }^{23}$ Two major criteria, one major criterion and two minor criteria, or one major and genetic confirmation are required for diagnosis.

\begin{tabular}{ll}
\hline Major criteria & Minor criteria \\
\hline $\begin{array}{l}\text { Multiple BCCs or one BCC in a person younger } \\
\text { than } 20 \text { years }\end{array}$ & Bifid, fused or splayed ribs \\
\hline Odontogenic keratocysts & $\begin{array}{l}\text { Other specific skeletal and radiologic abnormalities } \\
\text { (i.e. pectus excavatum, scoliosis, hemivertebrae, } \\
\end{array}$ \\
$\begin{array}{l}\text { Sprengel's deformity, syndactyly of digits, bony } \\
\text { bridging of the sella turcica, flame-shaped } \\
\text { lucencies of phalanges) }\end{array}$ \\
\hline Palmar or plantar pits & Macrocephaly \\
\hline Medulloblastoma in early childhood & Cleft lip or palate \\
\hline First-degree relative with BCNS & Ovarian or cardiac fibroma \\
\hline & Lymphomesenteric cysts \\
\hline
\end{tabular}




\section{Materials and methods}

A multicentre retrospective cohort study was conducted at the Maastricht University Medical Centre + (MUMC+), and the VU University Medical Centre (VUMC) the Netherlands. All blood samples sent to the two diagnostic DNA laboratories for PTCH1 standard mutation analysis by Sanger sequencing and multiplex ligation-dependent probe amplification in the period 19992015 were listed. During this period, the two laboratories processed requests from all hospitals in the Netherlands for PTCH1 mutation analysis, in addition to patients from various hospitals in Belgium, Norway, Finland, Portugal and Sweden. ${ }^{24}$ For all Dutch patients with a PTCH1 mutation, classified as pathogenic or probably pathogenic, detailed clinical information was retrieved from their medical records. Foreign patients were excluded because of practical difficulties.

A heat map was created in Microsoft Excel using conditional formatting to investigate a genotypephenotype correlation. A heat map is a two-dimensional representation of data that provides an immediate visualization of information. It is based on colour encoding and on meaningful reordering of the rows and columns. Using suitable colour scales, clustering can help to see structure and detect patterns. ${ }^{25}$ A red colour is given if the symptom is present, a green colour if the symptom is absent and a black colour if it is unknown. In this study, we used two different heat maps. In the first heat map the mutations are sorted according to their location within the gene, plotted against the clinical symptoms (BCCs, odontogenic keratocysts, palmoplantar pits, calcification of the falx cerebri, skeletal abnormalities and macrocephaly). In the second heat map, the mutations are sorted according to the type of mutation (frameshift or missense) against the clinical symptoms, since loss-of-function mutations are known to have more destructive effect on protein function (especially for a tumour suppressor), while missense mutations may have more subtle effects. ${ }^{14}$ Additionally, the different domains in the PTCH1 gene (N-terminal region, 2 extracellular loops, intracellular loop, sterol-sensing domain and C-terminal region) in which the mutation is located were included in the heat maps. Because symptoms requiring a second hit (BCCs and OKCs) become evident later in life and may not be present in younger patients, age could have been a potential bias. Separate analyses were performed successively excluding patients under 12 and 18 year. 


\section{Results}

From 1999 until 2015 PTCH1 variant analysis was performed in 673 patients. In 141 (21.0\%) of these individuals a PTCH1 variant was detected and 117 different PTCH1 variations were found. Of those, 110 were classified as pathogenic or probably pathogenic. ${ }^{24,26}$ After excluding foreign applications and non-pathogenic mutations, a pathogenic PTCH1 mutation was detected in 95 patients from the Netherlands (average population of 16,330,500). Clinical data could not be obtained for 12 patients, so 83 patients from 77 families were included for further analysis: 37 males and 46 females (ratio 1:1.2). The age of diagnosis ranged from 0-69 years, with a mean age of 25.2 years. Reasons for genetic testing written on the application forms were: 1 ) clinical suspicion of BCNS (37.3\%); 2) clinical diagnosis of BCNS (37.3\%); 3) first degree family member with BCNS (20.4\%); and 4) family members with symptoms of BCNS (3.6\%). In total four individuals were tested within the context of prenatal screening, because of a first-degree family member with BCNS or a clinical suspicion based on a second trimester ultrasound scan.

The type of mutations detected in this study were nonsense in 32.5\% (27/83), frameshift in $32.5 \%$ (27/83), missense in 12.0\% (10/83), splicing in 13.3\% (11/83) or a whole PTCH1 gene deletion in 3.6\% (3/83). The remaining 6.0\% (5/83) of mutations were in-frame duplications and deletions.

The mean age of diagnosis of the first BCC was 23.3 years. Compared to nonsense and frameshift mutations, the mean age at diagnosis of the first BCC is slightly higher in case of missense mutations (26.3 years vs 23.2 years). The clinical symptoms found in our cohort of BCNS patients are shown in table 3 .

\section{Comparing the diagnostic criteria}

Of all 83 included individuals, 80 (96.4\%) fulfilled the revised criteria by Bree et al (table 2). The remaining three patients did not meet the diagnostic criteria, but actually did have a PTCH1 mutation. One four-year-old patient with a nonsense mutation fulfilled four minor criteria (rib anomalies, macrocephaly, cardiac fibroma and ocular abnormalities), a three-year-old patient with an inframe deletion had one minor criterion (Sprengel deformity) and one 39-year-old patient with a missense mutation had two minor criteria (polydactyly and ocular anomalies). Based on the clinical criteria of Kimonis et al (table 2) the diagnosis of BCNS would have been made in 79 (95.2\%) out of 83 patients. Of the remaining four patients, the three-years-old patient and 39-years-old patient mentioned above did not meet the Kimonis criteria. In the other two patients PTCH1 mutation analysis was performed prenatally because of family members with BCNS. 


\section{Genotype-phenotype correlation}

Of all recorded clinical symptoms, only BCCs, OKCs, palmoplantar pits, calcification of the falx cerebri, skeletal abnormalities and macrocephaly were used for analysis. Other clinical symptoms, such as rib anomalies and ocular anomalies were excluded, because (specific) data were missing for many cases. To create robust heat maps, patients with less than two known symptoms were excluded. In total 78 patients were analysed.

In the first heat map, that compares the localization of the mutation with the presence of clinical symptoms (Figure 1), we could not visualize specific clustering of symptoms in an exon or part of the PTCH1 gene. Furthermore, no phenotype similarities could be found within families. In the second heat map, based on the type of mutation (Figure 2), including only missense (10) and truncating (49) (frameshift and nonsense) mutations, we could not identify an association between the type of mutation and clinical symptoms. Excluding patients younger then the age of 12 and 18 did not change our findings. Of note, the missense mutations were predominantly located in the transmembrane domains and specifically in the sterol-sensing domain (SSD). 
Table 3. The frequency of clinical symptoms in our Dutch cohort of BCNS patients.

\begin{tabular}{|c|c|c|}
\hline Major criteria & $\begin{array}{l}\text { Numbe } \\
\text { In/tota }\end{array}$ & (\%) \\
\hline 1. Multiple BCCs or BCC prior to 20 years of age & $53 / 71$ & 74.6 \\
\hline 2. OKCs of the jaws prior to 20 years of age & $61 / 74$ & 82.4 \\
\hline 3. Palmar and plantar pitting & $42 / 59$ & 71.2 \\
\hline 4. Lamellar calcification of the falx cerebri & $21 / 40$ & 52.5 \\
\hline 5. Medulloblastoma & $1 / 83$ & 1.2 \\
\hline 6. First degree relative with $\mathrm{BCNS}$ & $37 / 64$ & 57.8 \\
\hline Minor criteria & & \\
\hline 1. Rib anomalies (bifid, fused, splayed) & $25 / 41$ & 61.0 \\
\hline $\begin{array}{l}\text { 2. Other specific skeletal malformations and radiologic changes } \\
\text { (i.e., vertebral anomalies, scoliosis,pectus deformity, Sprengel } \\
\text { deformity, short fourth metacarpals, postaxial polydactyly) }\end{array}$ & $43 / 54$ & 79.6 \\
\hline 3. Macrocephaly & $44 / 51$ & 86.3 \\
\hline 4. Cleft/lip palate & $5 / 29$ & 17.2 \\
\hline 5. Ovarian/cardiac fibroma & $13 / 54$ & 24.1 \\
\hline Ovarian fibroma/cysts & $10 / 54$ & 18.5 \\
\hline Cardiac fibroma & $3 / 54$ & 5.6 \\
\hline 6. Lymphomesenteric cysts & $1 / 83$ & 1.2 \\
\hline $\begin{array}{l}\text { 7. Ocular abnormalities (i.e., hypertelorism, strabismus, congenital } \\
\text { cataracts, glaucoma, coloboma) }\end{array}$ & $32 / 41$ & 78.0 \\
\hline $\begin{array}{l}\text { Other malignancies (squamous cell carcinoma, adenocarcinoma } \\
\text { abdominal cavity, brain tumour, melanoma, meningioma, iris tumour) }\end{array}$ & $6 / 83$ & 7.2 \\
\hline
\end{tabular}

* Note that the denominator is not constant due to missing data 


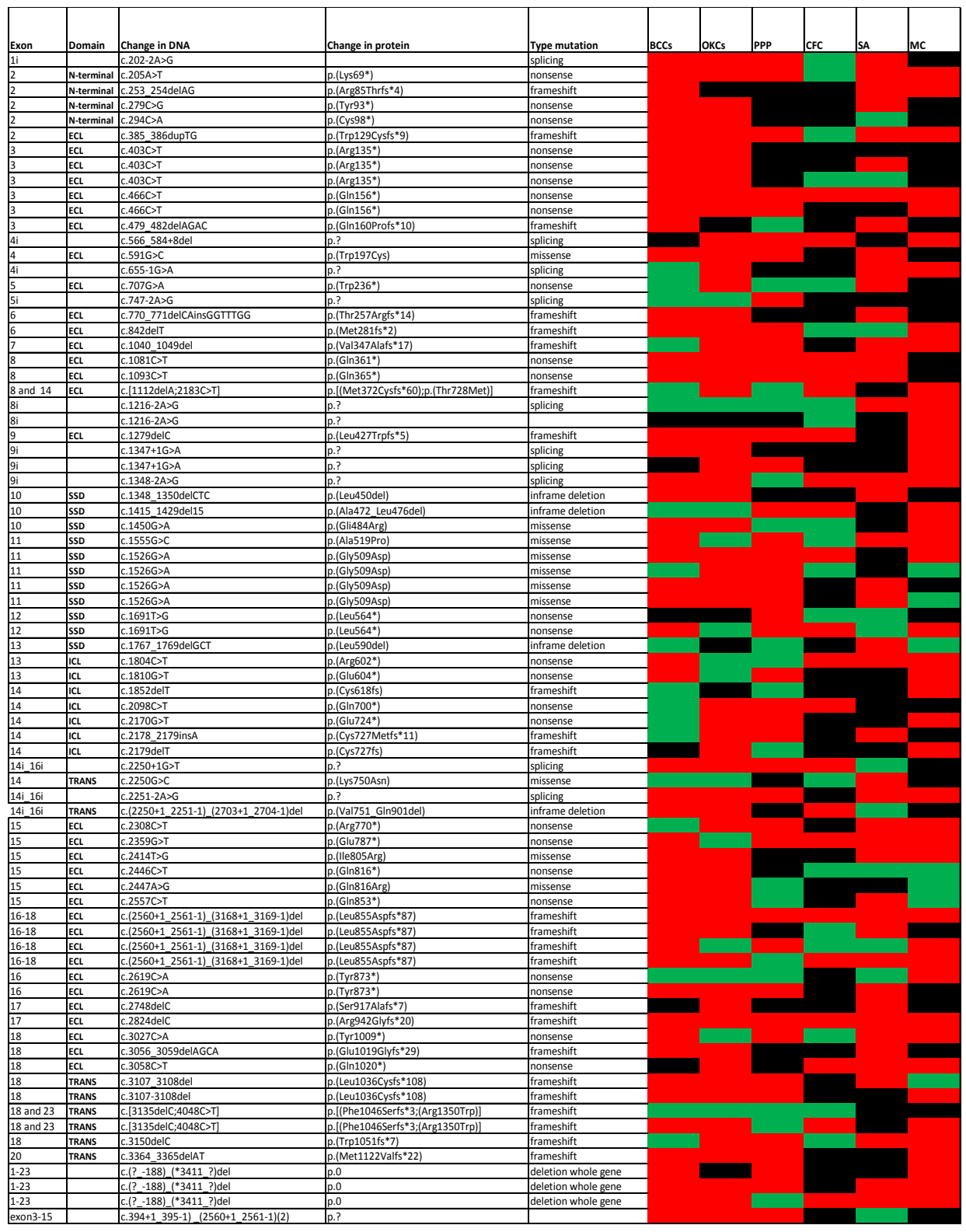

Figure 1. Heatmap. Genotype versus clinical symptoms (Basal cell carcinomas (BCCs), odontogenic keratocysts (OKCs), palmoplantar pits (PP), calcification of the falx cerebri (CFC), skeletal abnormalities (SA) and macrocephaly (MC)) in 78 individuals. Clinical symptoms are shown in red (present), green (absent) and black (unknown). Domains are noted as N-terminal region, ECL: Extracellular loop, ICL: Intracellular loop, SSD: Sterol-sensing domain and TRANS: Transmembrane domain. 


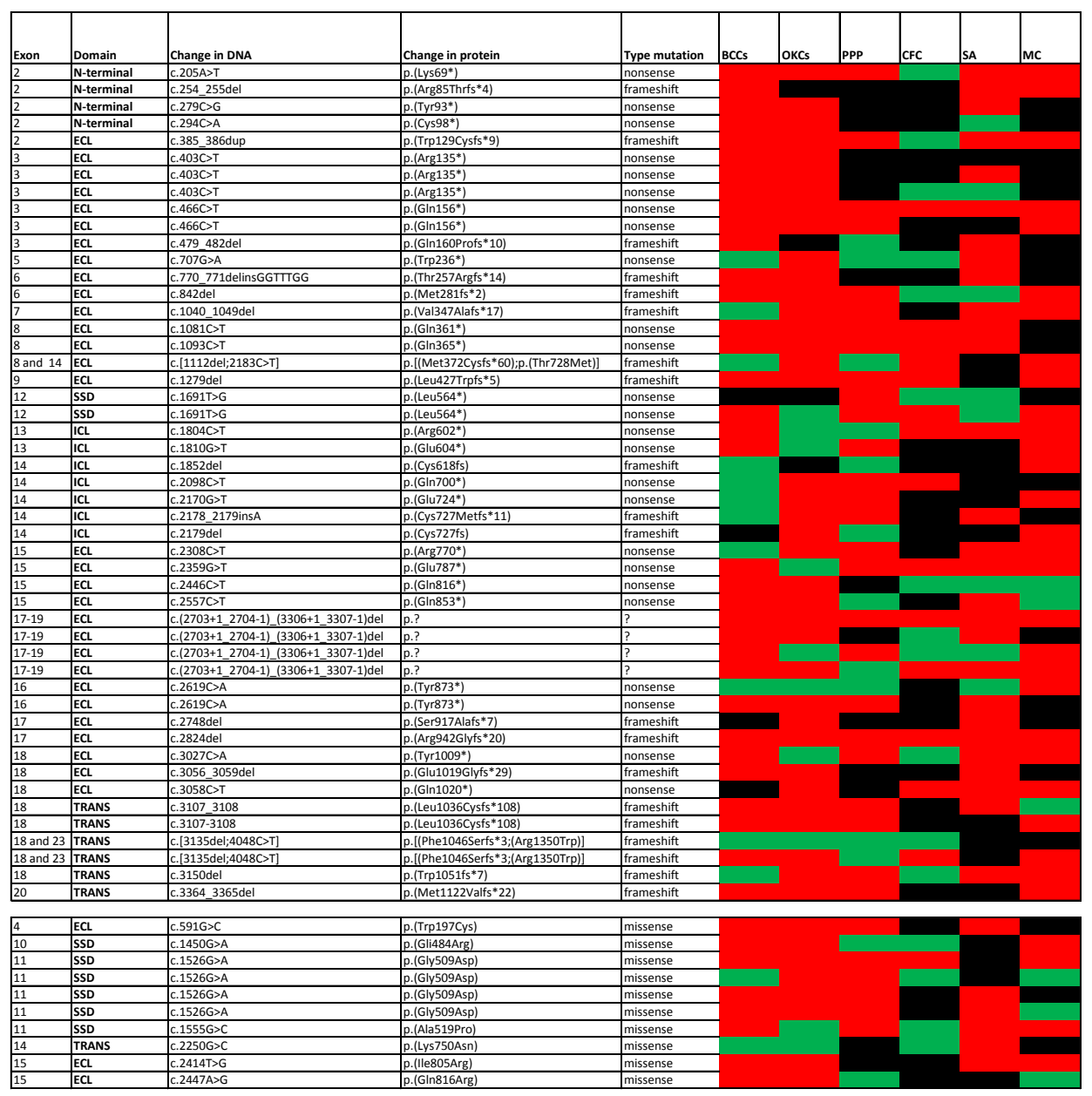

Figure 2. Heat map. Type of mutation (truncated and missense) versus clinical symptoms (Basal cell carcinomas (BCCs), odontogenic keratocysts (OKCs), palmoplantar pits (PP), calcification of the falx cerebri (CFC), skeletal abnormalities (SA) and macrocephaly (MC)) in 59 individuals. Clinical symptoms are shown in red (present), green (absent) and black (unknown). Domains are noted as N-terminal region, ECL: Extracellular loop, ICL: Intracellular loop, SSD: Sterol-sensing domain and TRANS: Transmembrane domain. 


\section{Discussion}

The goal of this study was to assess whether there is a genotype-phenotype correlation in BCNS. Detection of a genotype-phenotype correlation in BCNS patients would enable to predict phenotype severity and offer proper surveillance programs.

This study is one of the largest studies conducted to detect a genotype-phenotype correlation in BCNS patients. In our Dutch cohort, we did not find a correlation based either on the location or on the type of PTCH1 mutation. Even within families or individuals with a shared PTCH1 mutation, there was a high phenotypic variability. These findings are consistent with previous studies (Table 4). ${ }^{14,20-22}$

A recently published study by Evans et al has shown a number of key clinical features that may be predictive for the presence and type of a pathogenic germline PTCH1 variant. ${ }^{27}$ In this study, patients with missense variants in PTCH1 were diagnosed later and were less likely to develop at least ten BCCs, multiple OKCs, and bifid ribs than those with other PTCH1 variants. Our study shows comparable results as patients with a missense variant in PTCH1 were diagnosed later (31.7 years) compared to patients with frameshift or nonsense mutations (24.6 years), were less likely to develop rib anomalies (10\% vs. 32\% respectively) and the mean age at diagnosis of the first BCC is slightly higher (26.3 years vs 23.2 years respectively).

Notably, the found missense mutations in our study are predominantly located in the sterolsensing domain (SSD) (Figure 2). This is in line with the findings of Lindström et al. who analyzed the distribution pattern of germline PTCH1 mutations in BCNS patients and also demonstrated that missense mutations were predominantly found in the transmembrane domains of the SSD. ${ }^{28}$ Generally, SSDs are functional important regions and thought to function as a regulatory domain linking vesicle trafficking and protein localization in processes such as cholesterol homeostasis and cell signalling. ${ }^{29-31}$ Probably, missense mutations only have important consequences for the function of the PTCH1 protein, when located in the SSD. A recent study showed that the presence of common genetic variants, that are associated with an increased risk of developing sporadic BCC, like MC1R and TERT-CLPTM1L, are also associated with an earlier age of onset of BCCs in patients with BCNS. ${ }^{32}$ 


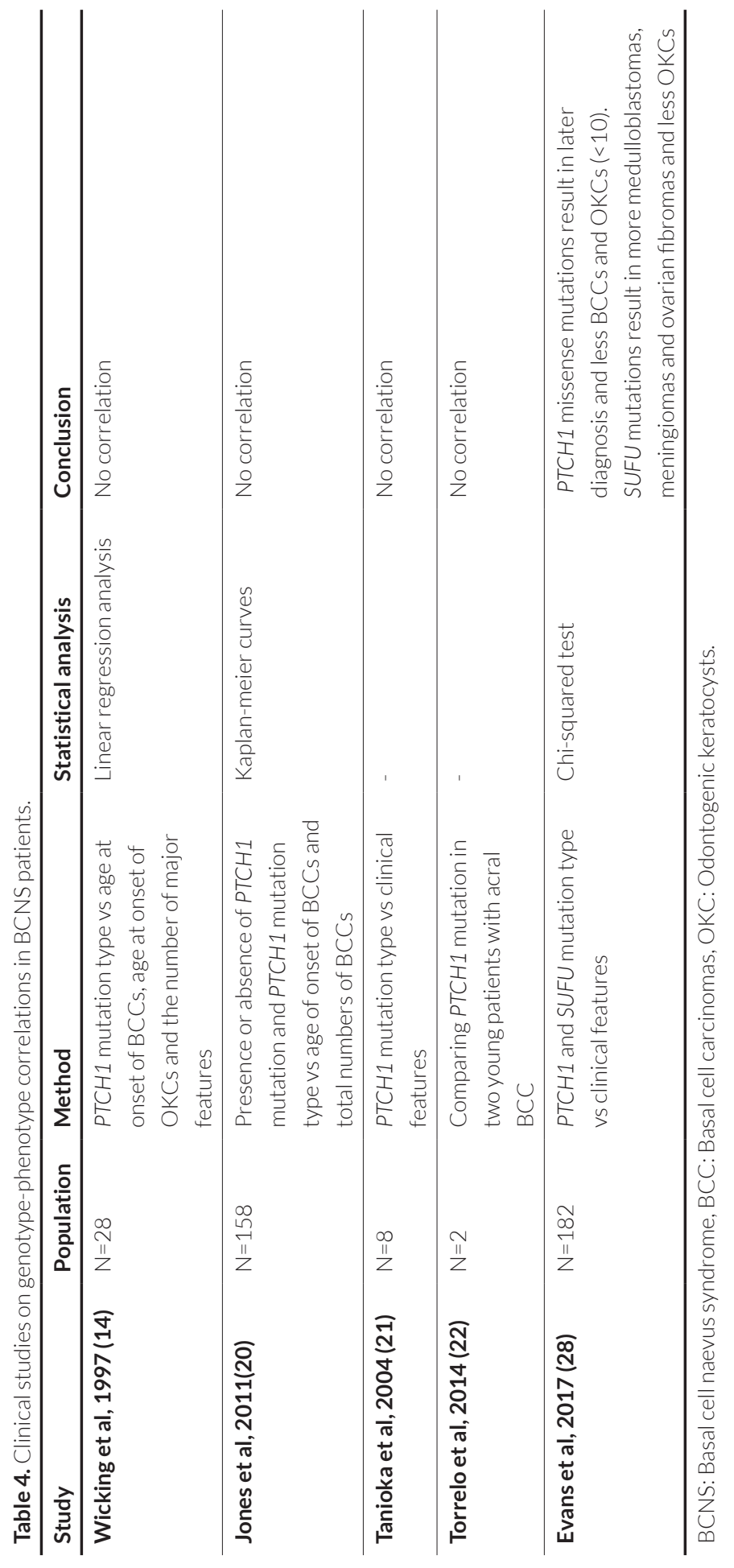


Due to the retrospective nature of this study, specific clinical information was sometimes missing. Symptoms were obtained from clinical files that have been listed according to the old diagnostic criteria. Symptoms that were not part of the old criteria, but are added in the new criteria such as cardiac fibroma and lymphomesenteric cysts, are probably underdocumented. In our study the mutation detection rate is low (21\%). A possible explanation for this is that genetic testing is relatively easily accesible in The Netherlands. The treshold to request genetic testing to exclude BCNS cases is probably low. On top of that standard genetic tests do not detect genomic rearrangments or deep intronic variants causing cryptic splicing in $\mathrm{PTCH} 1 .{ }^{33}$ And mutations could be located in other components of the Hh pathway. Moreover, mutation loads under 5\%, that can be present in low-grade mosaicism, are impossible to detect with Sanger sequencing. With the currently available techniques the estimated mutation prevalence would probably be higher.

Whole Exome Sequencing (WES), that is more and more used to diagnose heterogeneous disease phenotypes, enables the sequencing of all genes. The method is however still costly and has a limited sequencing depth. In case of a high clinical suspicion of BCNS it is more efficient to look specifically at components of the Hh pathway. The use of a next-generation sequencing (NGS) based gene panel, specifically developed for the analysis of genes involved in the Hh pathway is not only more sensitive, but also less expensive. In case of suspected mosaicism, NGS of target genes (i.e. PTCH1) has sufficient sequence read depth to reliably detect and quantify the degree of mosaicism. Notably, BCNS is not exclusively caused by mutations in the PTCH1 gene, other genes of the Hh signalling pathway, such as SUFU and PTCH2, should be part of the NGS gene panel. ${ }^{8-11}$

\section{Conclusion}

In a large cohort of Dutch BCNS patients, a high genotypic and phenotypic variability was found with no evidence for a genotype-phenotype correlation. 


\section{References}

1. Gorlin RJ, Goltz RW. Multiple nevoid basal-cell epithelioma, jaw cysts and bifid rib. A syndrome. N Engl J Med. 1960;262:908-12.

2. John AM, Schwartz RA. Basal cell naevus syndrome: an update on genetics and treatment. Br J Dermatol. 2016;174(1):68-76.

3. Hahn H, Wicking C, Zaphiropoulous PG, Gailani MR, Shanley S, Chidambaram A, et al. Mutations of the human homolog of Drosophila patched in the nevoid basal cell carcinoma syndrome. Cell. 1996;85(6):841-51.

4. Johnson RL, Rothman AL, Xie J, Goodrich LV, Bare JW, Bonifas JM, et al. Human homolog of patched, a candidate gene for the basal cell nevus syndrome. Science. 1996;272(5268):1668-71.

5. Hong Y, Zhang J, Zhang H, Li X, Qu J, Zhai J, et al. Heterozygous PTCH1 Mutations Impact the Bone Metabolism in Patients With Nevoid Basal Cell Carcinoma Syndrome Likely by Regulating SPARC Expression. J Bone Miner Res. 2016;31(7):1413-28.

6. Carlson ER, Oreadi D, McCoy JM. Nevoid Basal Cell Carcinoma Syndrome and the Keratocystic Odontogenic Tumor. J Oral Maxillofac Surg. 2015;73(12 Suppl):S77-86.

7. Knudson AG. Mutation and cancer: statistical study of retinoblastoma. Proceedings of the National Academy of Sciences. 1971;68(4):820-3.

8. Pastorino L, Ghiorzo P, Nasti S, Battistuzzi L, Cusano R, Marzocchi C, et al. Identification of a SUFU germline mutation in a family with Gorlin syndrome. Am J Med Genet A. 2009;149A(7):1539-43.

9. Smith MJ, Beetz C, Williams SG, Bhaskar SS, O'Sullivan J, Anderson B, et al. Germline mutations in SUFU cause Gorlin syndrome-associated childhood medulloblastoma and redefine the risk associated with PTCH1 mutations. J Clin Oncol. 2014;32(36):4155-61.

10. Fan Z, Li J, Du J, Zhang H, Shen Y, Wang CY, et al. A missense mutation in PTCH2 underlies dominantly inherited NBCCS in a Chinese family. J Med Genet. 2008;45(5):303-8.

11. Fujii K, Ohashi H, Suzuki M, Hatsuse H, Shiohama T, Uchikawa H, et al. Frameshift mutation in the PTCH2 gene can cause nevoid basal cell carcinoma syndrome. Fam Cancer. 2013;12(4):611-4.

12. Evans DG, Ladusans EJ, Rimmer S, Burnell LD, Thakker N, Farndon PA. Complications of the naevoid basal cell carcinoma syndrome: results of a population based study. J Med Genet. 1993;30(6):460-4.

13. Kimonis VE, Goldstein AM, Pastakia B, Yang ML, Kase R, DiGiovanna JJ, et al. Clinical manifestations in 105 persons with nevoid basal cell carcinoma syndrome. Am J Med Genet. 1997;69(3):299-308.

14. Wicking C, Shanley S, Smyth I, Gillies S, Negus K, Graham S, et al. Most germ-line mutations in the nevoid basal cell carcinoma syndrome lead to a premature termination of the PATCHED protein, and no genotype-phenotype correlations are evident. Am J Hum Genet. 1997;60(1):21-6.

15. Klein RD, Dykas DJ, Bale AE. Clinical testing for the nevoid basal cell carcinoma syndrome in a DNA diagnostic laboratory. Genet Med. 2005;7(9):611-9.

16. Marsh A, Wicking C, Wainwright B, Chenevix-Trench G. DHPLC analysis of patients with Nevoid Basal Cell Carcinoma Syndrome reveals novel PTCH missense mutations in the sterol-sensing domain. Human mutation. 2005;26(3):283.

17. Soufir N, Gerard B, Portela M, Brice A, Liboutet M, Saiag P, et al. PTCH mutations and deletions in patients with typical nevoid basal cell carcinoma syndrome and in patients with a suspected genetic predisposition to basal cell carcinoma: a French study. British journal of cancer. 2006;95(4):548-53.

18. Evans DG, Farndon PA, Burnell LD, Gattamaneni HR, Birch JM. The incidence of Gorlin syndrome in 173 consecutive cases of medulloblastoma. Br J Cancer. 1991;64(5):959-61. 
19. Garre ML, Cama A, Bagnasco F, Morana G, Giangaspero F, Brisigotti M, et al. Medulloblastoma variants: age-dependent occurrence and relation to Gorlin syndrome--a new clinical perspective. Clin Cancer Res. 2009;15(7):2463-71.

20. Jones EA, Sajid MI, Shenton A, Evans DG. Basal cell carcinomas in gorlin syndrome: a review of 202 patients. J Skin Cancer. 2011;2011:217378.

21. Tanioka M, Takahashi K, Kawabata T, Kosugi S, Murakami K, Miyachi Y, et al. Germline mutations of the PTCH gene in Japanese patients with nevoid basal cell carcinoma syndrome. Arch Dermatol Res. 2005;296(7):303-8.

22. Torrelo A, Vicente A, Navarro L, Planaguma M, Bueno E, Gonzalez-Sarmiento R, et al. Early-onset acral basal cell carcinomas in Gorlin syndrome. Br J Dermatol. 2014;171(5):1227-9.

23. Bree AF, Shah MR, Group BC. Consensus statement from the first international colloquium on basal cell nevus syndrome (BCNS). Am J Med Genet A. 2011;155A(9):2091-7.

24. Reinders M, van Hout A, Cosgun B, Paulussen A, Leter E, Steijlen P, et al. New mutations and an updated database for the patched-1 (PTCH1) gene. . Accepted for publication in Molecular Genetics \& Genomic Medicine Submitted. 2017.

25. Gehlenborg N, Wong B. Points of View: Heat maps. Nat Methods. 2012;9(3):213.

26. van Geel M, Gille J. Variants of patched 1 (PTCH1): Leiden University Medical Centre; 2004-2016 [Leiden Open Variation Database (LOVD) 3.0]. Available from: http://databases.lovd.nl/shared/ transcripts/00017082.

27. Evans DG, Oudit D, Smith MJ, Rutkowski D, Allan E, Newman WG, et al. First evidence of genotypephenotype correlations in Gorlin syndrome. J Med Genet. 2017;54(8):530-6.

28. Lindstrom E, Shimokawa T, Toftgard R, Zaphiropoulos PG. PTCH mutations: distribution and analyses. Hum Mutat. 2006;27(3):215-9.

29. Kuwabara PE, Labouesse M. The sterol-sensing domain: multiple families, a unique role? Trends Genet. 2002;18(4):193-201.

30. Martin V, Carrillo G, Torroja C, Guerrero I. The sterol-sensing domain of Patched protein seems to control Smoothened activity through Patched vesicular trafficking. Curr Biol. 2001;11(8):601-7.

31. Strutt H, Thomas C, Nakano Y, Stark D, Neave B, Taylor AM, et al. Mutations in the sterol-sensing domain of Patched suggest a role for vesicular trafficking in Smoothened regulation. Curr Biol. 2001;11(8):608-13.

32. Yasar B, Byers HJ, Smith MJ, Lear J, Oudit D, Bholah Z, et al. Common variants modify the age of onset for basal cell carcinomas in Gorlin syndrome. Eur J Hum Genet. 2015;23(5):708-10.

33. Bholah Z, Smith MJ, Byers HJ, Miles EK, Evans DG, Newman WG. Intronic splicing mutations in PTCH1 cause Gorlin syndrome. Fam Cancer. 2014;13(3):477-80. 



\title{
Chapter 4
}

\author{
Postzygotic mosaicism in basal \\ cell naevus syndrome
}

M.G.H.C. Reinders, H.J. Boersma, E.M. Leter, M. Vreeburg, A.D.C. Paulussen, A.H.M.M. Arits, G.M.J.M. Roemen, E.J.M. Speel, P.M. Steijlen, M. van Geel", K. Mosterd* 


\section{Abstract}

Basal cell naevus syndrome (BCNS) is an autosomal dominant disorder most commonly caused by a germline mutation in the Drosophila homolog of patched-1 (PTCH1) gene. Here we describe a patient with clinical signs of BCNS, caused by postzygotic mosaicism of a PTCH1 gene mutation. We performed Restriction Fragment Length Polymorphism analysis and Droplet Digital Polymerase Chain Reaction to determine the degree of mosaicism in different tissues of this patient. Our case shows that a relatively low-grade mosaicism can lead to clinical signs reminiscent to those caused by a germline mutation. This finding has important implications for genetic counselling and therefore is pivotal to recognize for dermatologists as well as for clinical geneticists and clinical laboratory geneticists. 


\section{Introduction}

Basal cell naevus syndrome (BCNS, MIM \#109400), also known as Gorlin syndrome, is an autosomal dominant disorder characterized by multiple basal cell carcinomas (BCCs), maxillary keratocysts and cerebral calcifications. ${ }^{1}$ The incidence of BCNS is estimated at 1 in 50,000 to 256,000. ${ }^{2}$ Diagnostic criteria for BCNS were first established by Evans et al., modified by Kimonis et al. and revised by Bree and Shah in 2011..$^{3-5}$ Diagnosis is based on two major criteria, one major criterion and two minor criteria or one major criterion and genetic confirmation (Table 1, Chapter 1). The cause of BCNS generally is a germline mutation in the Drosophila homolog of patched-1 (PTCH1) gene that encodes the PTCH1 protein. ${ }^{6}, 7$ Postzygotic mosaicism has been described in BCNS. 8.9 In postzygotic mosaicism a mutation occurs somewhere during embryogenesis, only affecting cells from the mutant progenitor, resulting in mixed healthy and affected cell populations. Depending on the mutation load and the tissues involved in the mosaicism, an individual with postzygotic mosaicism may develop clinical signs to a certain degree or none at all. ${ }^{10}$ Type 1 and type 2 mosaicism as a cause of segmental distribution of clinical symptoms in BCNS have been described. 9,11 Germline cells can be affected by genetic mosaicism as well, referred to as gonadal mosaicism. In theory, when the mutation load in gonadal cells is lower than the regular 50\% in classic germline BCNS patients, the recurrence risk of BCNS in the patient's offspring probably is lower than $50 \%$. 


\section{Case}

A 22-year-old woman was referred to our outpatient clinic with a BCC in the medial canthus of the right eye (Figure 1A). During total body skin examination, we detected two additional BCCs below her right eye and palmar pits on both hands (Figure 1B). An orthopantomography was negative for odontogenic keratocysts and a MRI of the head showed no cerebral calcifications. Based on the presence of two major clinical criteria, BCNS was diagnosed.

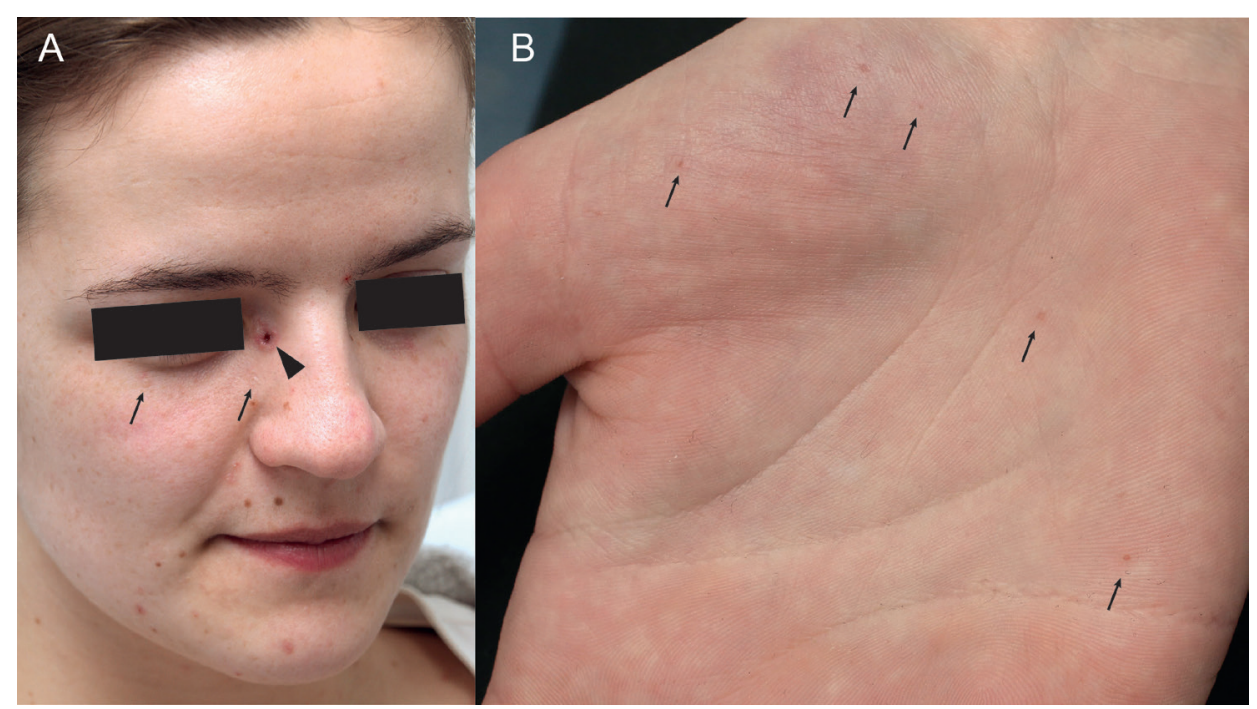

Figure 1A. Patient with a BCC in the medial canthus of the right eye (arrowhead) and two additional small BCCs (arrows) and B. Multiple palmar pits (arrows).

Sanger sequencing analysis of the protein-coding exons and flanking introns of the PTCH1 gene (primer sequences on request) on DNA extracted from blood (Wizard Genomic DNA purification Kit, Promega) detected a barely observable mutation in exon 13, c.1810G>T (NCBI RefSeq: NM_000264.3). Although Sanger sequencing is not a quantitative method, the mutation seemed to have a remarkably lower level then one would expect in case of a germline mutation (Figure 2A). Based on this finding we hypothesized that a postzygotic mutation in the PTCH1 gene, resulting in genetic mosaicism, was responsible for the clinical presentation of our patient. The mutation results in the alteration of a glutamic acid resulting in a stop at position 604 (p.(Glu604*)) of the PTCH1 protein. This premature termination codon likely results in a non-functional shorter protein. This mutation has not been detected in databases (dbSNP, EXAC) nor described in literature before, although a similar mutation (p.(Arg602*)) has been described in a family with BCNS.12 
In postzygotic mosaicism, the percentage of affected cells can vary between different tissues and may be segmentally distributed. To determine the degree of mosaicism in other tissues, we isolated DNA from urine derived urothelial cells and buccal mucosa cells of the patient (Wizard Genomic DNA purification Kit, Promega). On these samples we performed Restriction Fragment Length Polymorphism (RFLP) analysis with restriction enzyme Bfal (digesting the mutant allele, figure 2B). In addition, we performed Droplet Digital PCR (QX200 ddPCR, BioRad Laboratories, Hercules, CA, USA) on DNA of the same tissues and BCC tumour cells of this patient (DNA isolation with Maxwell 16 FFPE plus LEV DNA Purification Kit, Maxwell 16 MDX, Promega) to determine the degree of mosaicism (Figure 2C). ddPCR technology makes use of standard TaqMan probe-based assays (Custom Taqman Assays, Catalog \#: 4331349, ID nr: AHN1XWW, Life Technologies Europe). The results are summarized in Table 2. Our patient has a low-grade mosaicism of approximately $16 \%$, based on the average of the different degrees of mosaicism determined by ddPCR.

Table 2. Tissues analysed for degree of genetic mosaicism. Percentages of DNA mutation load with BfalRFLP and Droplet Digital PCR. Assessment of the tumour sample with RFLP was not feasible because the PCR amplicon size (556 bp) was too large for analysis on fragmented formalin-fixed, paraffin-embedded tissue DNA.

\begin{tabular}{lll}
\hline Sample & Bfal RFLP & Droplet Digital PCR \\
\hline Blood & $6.4 \%$ & $13.5 \%$ \\
Urine derived endothelial cells & $14.7 \%$ & $17.3 \%$ \\
Buccal mucosa & $8.7 \%$ & $17.0 \%$ \\
Tumour & - & $36.1 \%$ \\
\hline
\end{tabular}


A
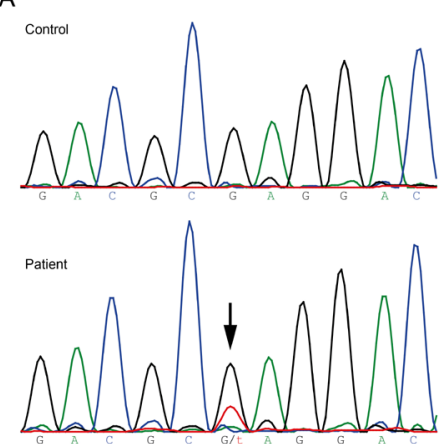

B
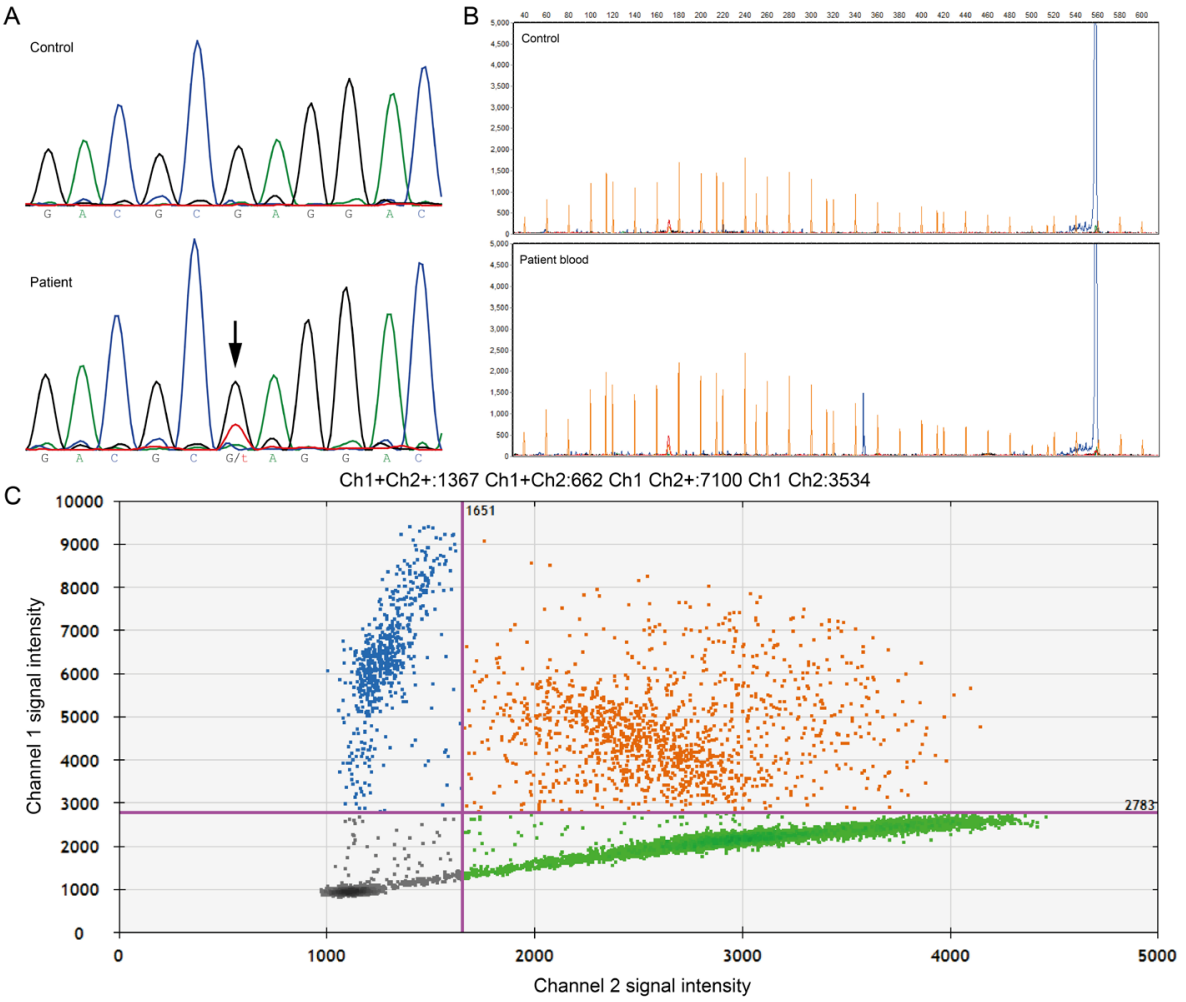

Figure 2. Analyses of genetic mosaicism in PTCH1 using different techniques $\mathbf{A}$. The PTCH1 sequence trace across the mutation. Top panel: control trace, lower panel: patient trace with c.1810G > T mutation (arrow) from leucocyte isolated DNA. B. RFLP analysis with Bfal of wild type DNA (top) and patient DNA isolated from blood (bottom). Fragment size is depicted horizontally in base pairs (bp), signal intensity vertically (Genemarker software V2.4.0, SoftGenetics LLC). The blue peaks represent the FAM-labelled PCR products; orange peaks fragment size standards (600 LIZ Size Standard). Percentage mosaicism was 6.4\% calculated by mutant peak (348 bp) surface area divided by total peak surface area (348+556 bp). C. Representative dot plot picture of results from ddPCR on DNA from the patient's blood. Fluorescence intensity for 6-FAM TaqMan probe is displayed vertically (channel 1) and VIC TaqMan probe horizontally (channel 2). Left upper quadrant (Ch1+Ch2) contains positive droplets (blue) for the mutant DNA fragments, right lower quadrant (Ch1 Ch2+) has positive droplets for wild type DNA fragments (green), right upper quadrant (Ch1+Ch2+) contains positive droplets for one or more wild type as well as mutant DNA fragments (orange) and the left lower quadrant (Ch1 Ch2) has empty negative droplets (black). Percentage mosaicism was $13.5 \%$ calculated from positive mutant (blue, proportion orange) droplets divided by the total number of DNA containing (blue, orange, green) droplets using a Poisson distribution (QuantaSoft software, Bio-Rad Laboratories). 


\section{Discussion}

Our findings confirm that a low-grade postzygotic mosaicism of a PTCH1 gene mutation can cause a clinical presentation fulfilling the diagnostic criteria for BCNS. Phenotypic variability between BCNS patients is common, even within families. ${ }^{13}$ Such variability exists between patients with genetic mosaicism as well. Therefore the phenotype may be difficult to predict, even when the degree of mosaicism is known. Segmental arrangement of symptoms has been described in mosaic BCNS. In this patient we did not observe this phenomenon, she also developed a BCC on the left cheek during dermatological follow-up. However, a segmental distribution could become apparent later in life.

Previously it has been suggested that in patients with segmental Darier disease the percentage of affected gonadal cells may be comparable to that of other tissues. ${ }^{14} \mathrm{~A}$ lower level of mosaicism can very well translate into a lower recurrence risk of BCNS for future offspring. Mutation analysis in gonadal cells (oocytes and spermatocytes) is extremely challenging. In our patient we could estimate the degree of gonadal mosaicism somewhere between 13 and $17 \%$, based on the percentages found with ddPCR in the different tissues. If the degree of gonadal cells with the PTCH1 gene mutation is below 50\%, transmission to the offspring probably will be lower than $50 \%$, maybe even as low as 13\%. Providing a more precise recurrence risk will be beneficial for genetic counselling. Only then, patients can make an adequate informed decision about prenatal diagnosis or preimplantation genetic diagnosis.

Different techniques can be used to determine the degree of mosaicism. With standard Sanger sequencing it may be difficult to detect low-grade mosaicism and impossible to quantify the degree of mosaicism. We used quantitative techniques, RFLP and ddPCR, leading to different results. RFLP analysis showed a lower degree of mosaicism compared to ddPCR. This difference may be due to less accurate calculation of the peak-surface-area in RFLP and lack of a complete digestion control in the Bfal RFLP. ddPCR does not have these limitations, since it makes use of massive partitioning of the sample. This way, thousands of individual data points are produced, rather than a single result, generating a powerful tool for statistical analysis. We therefore think that ddPCR will provide a better measure of the actual degree of mosaicism than RFLP.

As a control we performed ddPCR on patient's BCC tumour tissue DNA. In theory, the tumour sample has to consist of cells containing the c.1810G > T PTCH1 mutation along with an acquired second somatic mutation or loss of heterozygosity $(\mathrm{LOH})$ to inactivate the tumour suppressor function of PTCH1. Mutation load in the tumour therefore is expected to be $50 \%$ or more, respectively. ddPCR however, detected the mutation only in $36 \%$ of tumour DNA. This is probably due to the presence of a certain percentage of normal tissue, since we did not microdissect the tumour from the tissue. Histologically the percentage tumour in the sample was estimated to be 60-70\%. Based on these findings $\mathrm{LOH}$ is probably less likely than a second somatic mutation. 
In conclusion, our results show that a low-grade postzygotic mosaicism of a PTCH1 mutation can cause a clinical picture fulfilling the diagnostic criteria of BCNS. This is an important finding for dermatologists as well as for clinical geneticists and clinical laboratory geneticists. It underlines the importance to perform genetic tests in patients suspected of BCNS, even when they do not meet the clinical criteria, as it has implications for genetic counselling. Standard techniques are not always suitable to pick up low-grade postzygotic mosaicism, which makes additional quantitative techniques essential. When initial genetic tests in BCNS patients suggest an underlying genetic mosaicism, we recommend to determine the degree of mosaicism as accurately as possible, for example with ddPCR, for adequate genetic counselling. 


\section{References}

1. John AM, Schwartz RA. Basal cell naevus syndrome: an update on genetics and treatment. Br J Dermatol 2016;174:68-76.

2. Lo Muzio L. Nevoid basal cell carcinoma syndrome (Gorlin syndrome). Orphanet J Rare Dis 2008;3:32.

3. Evans DG, Farndon PA. Nevoid Basal Cell Carcinoma Syndrome. In: Pagon RA, Adam MP, Ardinger HH, et al., eds. GeneReviews(R). Seattle (WA)1993.

4. Kimonis VE, Goldstein AM, Pastakia B, et al. Clinical manifestations in 105 persons with nevoid basal cell carcinoma syndrome. Am J Med Genet 1997;69:299-308.

5. Bree AF, Shah MR, Group BC. Consensus statement from the first international colloquium on basal cell nevus syndrome (BCNS). Am J Med Genet A 2011;155A:2091-7.

6. Hahn H, Wicking C, Zaphiropoulous PG, et al. Mutations of the human homolog of Drosophila patched in the nevoid basal cell carcinoma syndrome. Cell 1996;85:841-51.

7. Johnson RL, Rothman AL, Xie J, et al. Human homolog of patched, a candidate gene for the basal cell nevus syndrome. Science 1996;272:1668-71.

8. Aradhya S, Lewis R, Bonaga T, et al. Exon-level array CGH in a large clinical cohort demonstrates increased sensitivity of diagnostic testing for Mendelian disorders. Genet Med 2012;14:594-603.

9. Torrelo A, Hernandez-Martin A, Bueno E, et al. Molecular evidence of type 2 mosaicism in Gorlin syndrome. Br J Dermatol 2013;169:1342-5.

10. Chial H. Somatic mosaicism and chromosomal disorders. Nature education 2008;1:69.

11. Camisa C, Rossana C, Little L. Naevoid basal-cell carcinoma syndrome with unilateral neoplasms and pits. Br J Dermatol 1985;113:365-7. 



\section{Chapter 5}

Genetic profiling of basal cell carcinomas detects postzygotic mosaicism in basal cell naevus syndrome

M.G.H.C. Reinders, B. Cosgun, L.M.C. Gijezen, C.N. van Oosterhoud, N.W.J. Kelleners-Smeets, E. Vermander, M. Vreeburg, P.M. Steijlen, K. Mosterd*, M. van Geel* 


\section{Abstract}

Basal cell naevus syndrome is associated with germline mutations in the PTCH1 gene. Also, postzygotic mosaicism can cause BCNS. Here we describe two patients, one with multiple basal cell carcinomas and one with clinically BCNS, who had no PTCH1 mutation in DNA extracted from blood. In both patients, we performed genetic analysis on different BCCs, revealing the presence of a shared PTCH1 mutation in all tumours. Our findings show that in patients with symptoms of BCNS and initial absence of a PTCH1 mutation in blood, genetic profiling of BCCs can detect postzygotic mosaicism. 


\section{Introduction}

Basal cell naevus syndrome (BCNS, MIM \#109400), also known as Gorlin syndrome, is an autosomal dominant disorder most commonly caused by a germline mutation in the patched-1 (PTCH1) gene. Characteristic features of this syndrome include multiple basal cell carcinomas (BCCs), odontogenic keratocysts, palmoplantar pits and cerebral calcifications. ${ }^{1}$ Diagnosis is based on two major criteria, one major criterion and two minor criteria or one major criterion and genetic confirmation using the revised criteria of Bree and Shah. ${ }^{2}$ Several cases of unilateral or segmental BCNS have been reported in the past. ${ }^{3-5}$ Recently we described a patient with a low-grade postzygotic mosaicism in PTCH1 as the cause of this syndrome. ${ }^{6}$ Another case of postzygotic mosaic BCNS caused by an activating mutation in $\mathrm{SMO}$, has been published. ${ }^{7}$ It has been argued though, if this case represents a mosaic manifestation of Gorlin syndrome or actually could be diagnosed with Happle-Tinschert syndrome, ${ }^{8}$ as the same activating mutation was detected in the original case of this syndrome. ${ }^{9}$ In type 1 segmental mosaicism or postzygotic mosaicism a mutation occurs somewhere during embryogenesis, only affecting cells from the mutant progenitor, resulting in mixed healthy and affected cell populations. Depending on the mutation load and the tissues involved, an individual with postzygotic mosaicism could develop limited clinical signs or may be asymptomatic. Type 2 segmental mosaicism in BCNS has been described as well. ${ }^{10}$ This type of mosaicism refers to an autosomal dominant disorder which is accompanied by a postzygotic mutation that affects the healthy allele, resulting in pronounced cutaneous symptoms of the disease in a mosaic pattern. In this paper, we present two patients with symptoms of BCNS, who had no PTCH1 mutation in blood with Sanger sequencing, where subsequent genetic profiling of their BCCs led to detection of postzygotic mosaicism. 


\section{Case 1}

A 41-year old woman was referred to our outpatient clinic because of a history of multiple BCCs exclusively on the right side of her body (Figure 1a and b). No other symptoms of BCNS were observed. Hundreds of BCCs were treated with excision, Mohs' micrographic surgery and photodynamic therapy. The patient was carrier of a BRCA2 gene mutation and her medical history mentioned left-sided breast cancer which was treated with mastectomy, radiotherapy and tamoxifen.

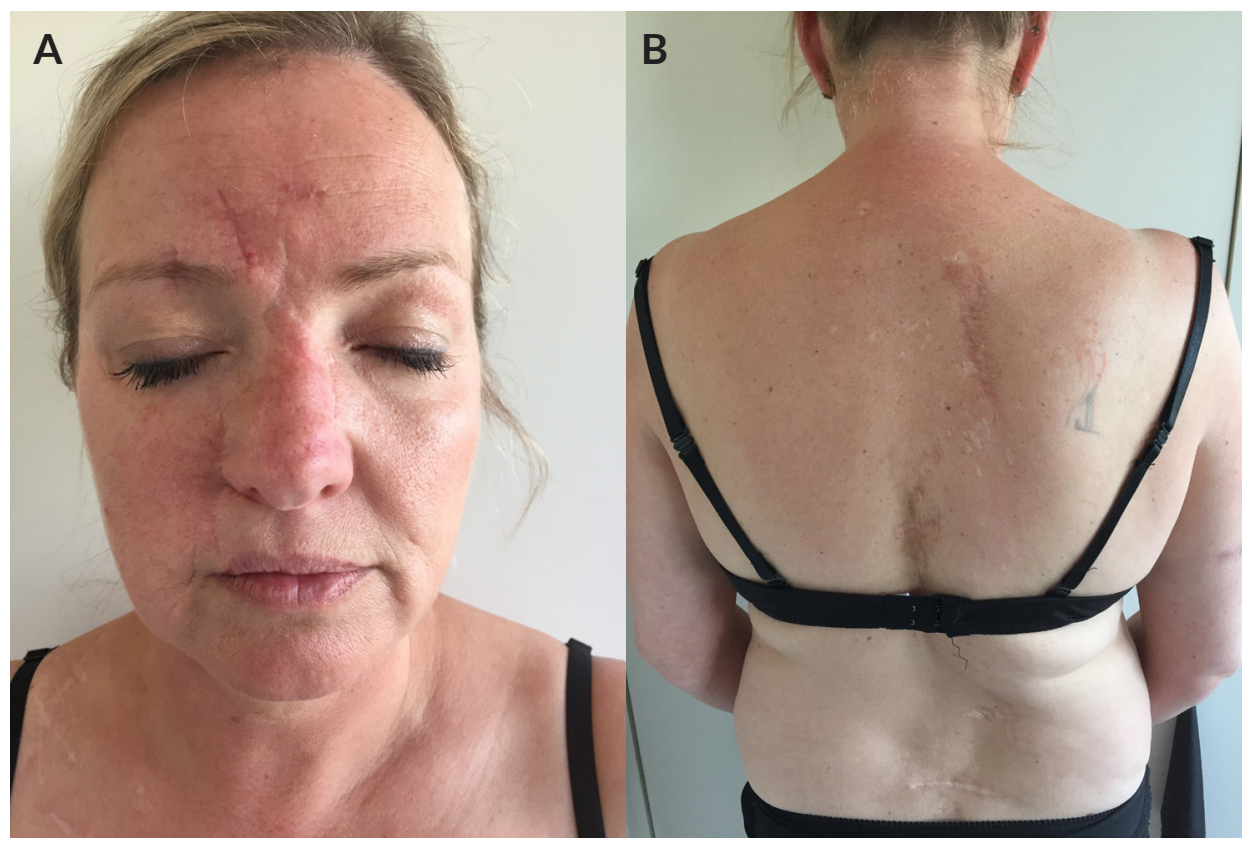

Figure 1. Photograph of female patient (case 1) showing right-sided distribution of multiple basal cell carcinomas and scars after excision on the face (A) and on the body (B).

Sanger sequencing of the coding exons of the PTCH1 gene (BigDye v1.1 sequencing kit, 3730 DNA Analyzer, Applied Biosystems, primer sequences on request) on DNA extracted from blood (Wizard Genomic DNA purification Kit, Promega) detected no mutation. Because of the unilateral distribution of BCCs we suspected postzygotic mosaicism. Mutation analysis with single molecule Molecular Inversion Probes (smMIPs) and Next Generation Sequencing (NGS, Illumina NextSeq) targeting the coding exons of PTCH1, PTCH2, SUFU and SMO (NCBI RefSegs resp. NM_000264.4, NM_003738.4, NM_016169.3, NM_005631.4) of four different BCCs on the right shoulder and upper arm revealed a shared exon 14 PTCH1 mutation in all tumours, designated c.2197_2198del (Table 1). In addition, the split half of the tumours were used for 
RNA analysis of PTCH1. In two of the BCCs a second somatic mutation was detected in PTCH1 (c.3054G >A in BCC1 and c.1603-1G>A in BCC3, also detected in cDNA analysis, the latter affecting splicing, table 1). In addition, we analysed multiple samples of visibly normal skin on both ends of the fusiform excision specimen of a BCC, fibroblasts grown from one of these ends, subcutaneous healthy tissue underneath the tumour and a biopsy of normal skin on the left, unaffected side of the body (Figure 2). Mutation analysis on BCC surrounding skin samples showed variable DNA mutation loads. No mutation was found with smMIPs-NGS in the skin biopsy from the left side of the body or in blood. These findings identified type 1 segmental mosaicism of PTCH1 as the cause of her multiple BCCs.

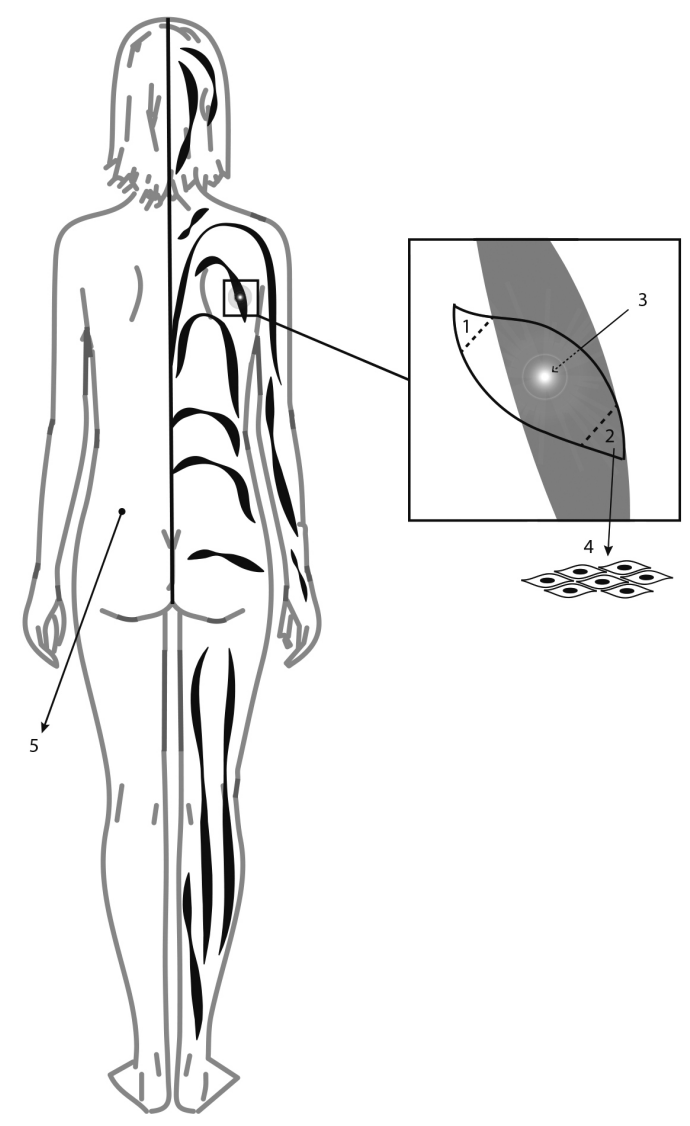

Figure 2. Segmental distribution of the PTCH1 mutation in the skin, potentially in a Blaschkoid pattern. The imaginary black lines represent the affected skin without a clinical phenotype, but harbouring a heterozygous PTCH1 mutation, following the lines of Blaschko. The location of a BCC is boxed and magnified on the right. Detected mutation loads in 1. Excision end 1: 1.0\%, 2. Excision end 2: 9.0\%, 3. Healthy subcutaneous tissue underneath the BCC: 0.6\%, 4. Fibroblast culture grown from excision end 2: $0 \%$ and 5 . Skin biopsy on the left unaffected side of the body (see also table 1). 


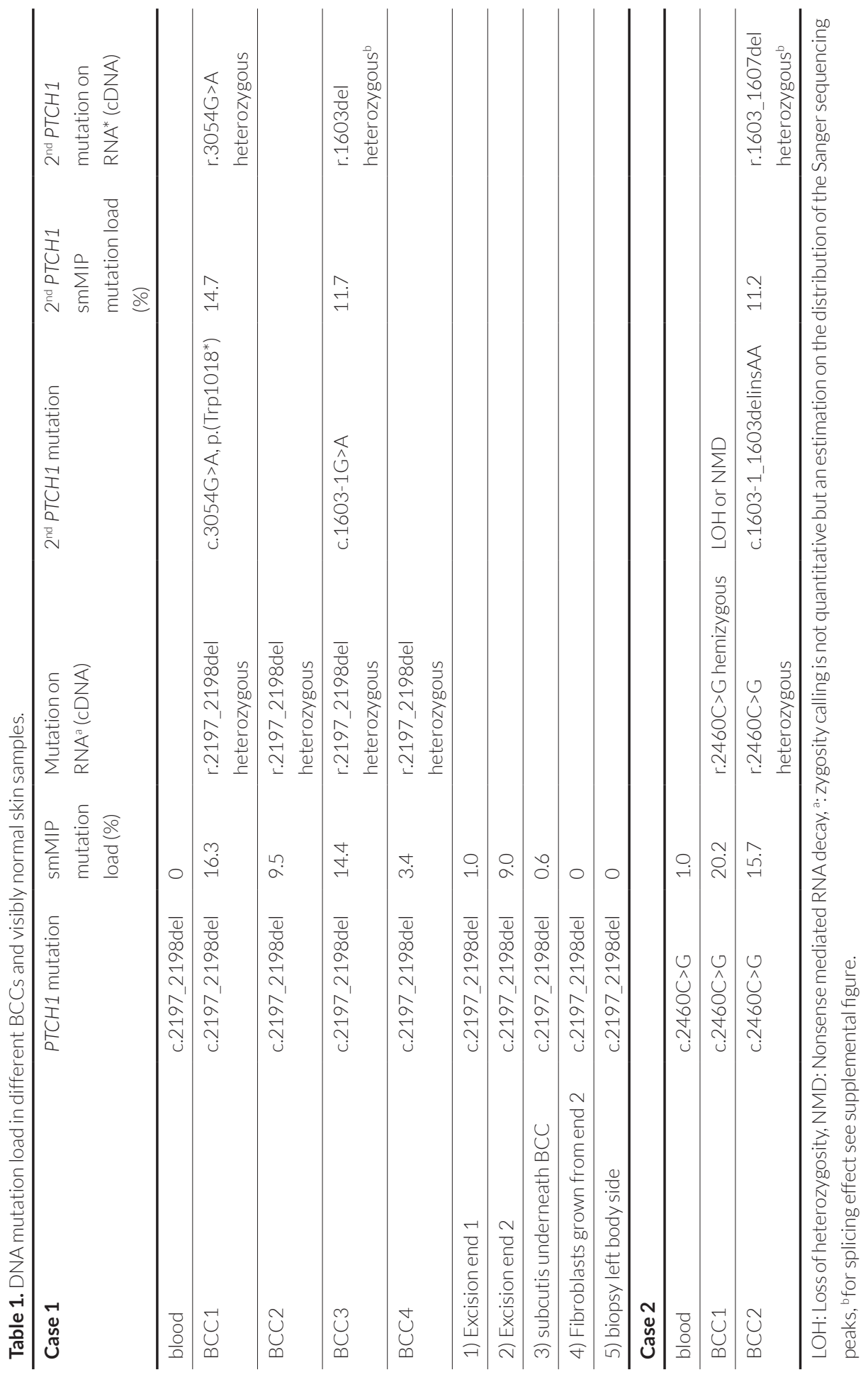




\section{Case 2}

A 36-year old woman was referred to our outpatient clinic with a very large basosquamous carcinoma on her forehead, which was treated with radiotherapy 9 years earlier. On physical examination, a thoracic scoliosis was noticed and several BCCs, diffusely distributed on the body, together with palmoplantar pits were detected. Based on the clinical criteria we diagnosed her with BCNS. ${ }^{10}$ Two mandibular odontogenic cysts were found. A cranial CT scan showed a skin tumour on the forehead with extensive bone destruction and invasion into dura and cranial part of the superior sagittal sinus. Curative surgery could not be achieved and after DIEP (deep inferior epigastric perforator) flap reconstruction, she was treated with radiation therapy (60-70 Gy). The remaining BCCs were treated with Mohs' micrographic surgery, conventional excision and 5-fluorouracilcrème.

Despite a clinical diagnosis of BCNS, Sanger sequencing and smMIP-NGS of the PTCH1 gene on DNA extracted from blood identified no mutation. Mutation analysis on RNA (Qiagen RNA isolation kit, iScript cDNA Synthesis Kit, BioRad, primer sequences on request) from 2 different BCCs on the right shoulder and left upper arm showed a shared mutation in exon 15 of PTCH1, designated c.2460C > G (p.(Tyr820*)). This mutation was also found with smMIP-NGS on DNA isolated from the split half of the two BCCs. The results are indicative for type I postzygotic mosaicism. Re-interpretation of the smMIP-NGS data on blood by visual inspection detected the mutation in $1.0 \%$ of the sequence reads, a percentage close to the detection limit with the used coverage depth ( $<1000 x)$. One of the tumours was hemizygous for the mutation on cDNA analysis, due to either loss-of-heterozygosity ( $\mathrm{LOH}$, chromosomal deletion or allele specific methylation) of the other allele or to nonsense mediated decay (NMD) caused by an intragenic PTCH1 mutation (exon-deletion/ -duplication or splicing). In the other tumour, a second splice site mutation was identified on DNA, whose functional effect was also detected with cDNA analysis (r. 1603_1607del, table 1). 


\section{Discussion}

Postzygotic mosaicism as the cause of BCNS can be difficult to detect in DNA from blood with standard Sanger sequencing techniques, as this method's mutation detection limit is approximately $5 \%$. NGS of a targeted gene panel is more sensitive and has sufficient sequence read depth to reliably detect and quantify the degree of mosaicism. In the present patients, a postzygotic mutation could not be demonstrated in blood with Sanger sequencing, but in patient 2 the smMIP-NGS technique did detect the PTCH1 mutation in blood in a very low percentage.

Some forms of segmental mosaicism of dominant mutations can easily be recognized when the presence of the mutation leads to visible skin lesions, such as in mosaic ichthyosis. ${ }^{11}$ Cutaneous mosaicisms follow different patterns. Lesions mostly follow the lines of Blaschko, in broad or narrow bands, or appear in a checkerboard pattern. ${ }^{12}$ In patients with BCNS, skin with only one affected PTCH1 allele has a normal appearance. Only a second hit of the other PTCH1 allele (through loss-of-heterozygosity ( $\mathrm{LOH}$ ) or somatic gene mutation), initiates the development of a basal cell carcinoma. As the presence of a BCC is a marker for affected skin, genetic mosaicism of a larger cell population in the skin, can be demonstrated when different BCCs share the same PTCH1 mutation. Our first patient clinically had a clear unilateral distribution of BCCs, already indicating genetic mosaicism. The results of the genetic analysis of the different tissue samples suggest a unilateral segmental distribution of the mutated skin following the lines of Blaschko (Figure 1 and 2). The mosaicism probably is restricted to the cells of the epidermis, as fibroblasts did not harbour the mutation and subcutaneous tissue underneath the tumour area only in a very low degree. The existence of a Blaschkoid pattern in mosaic BCNS is supported by two earlier reports of BCNS patients with a type 2 segmental PTCH1 mosaicism and a type 1 segmental mosaicism of SMO, showing a comparable pattern.,10 The second patient had no segmental distribution of symptoms, but the presence of an identical PTCH1 mutation in two BCCs, a second somatic PTCH1 mutation in one of the tumours and the low percentage of the mutation in blood strongly supports our conclusion that PTCH1 mosaicism is the cause of the disease. 
Type 1 segmental mosaicism as the cause of BCNS or a partial BCNS phenotype could be more common than previously assumed. It is plausible that these patients not always fulfil the diagnostic criteria of BCNS and even may only present with multiple BCCs at a young age. A segmental distribution of the BCCs is not always visible. Yet, it is important to be informed about the presence of mosaic BCNS as these patients may have other health problems and radiotherapy is contra-indicated for the treatment of their BCCs. Also patients with type 1 segmental genetic mosaicism have a slightly elevated risk of giving birth to a child with a heterozygous PTCH1 mutation, probably depending on the presence and degree of gonadal mosaicism. In patients with symptoms of BCNS and absence of a mutation in blood, it is worthwhile to search for a shared mutation in the different BCCs with an NGS based gene panel, to demonstrate genetic mosaicism. This information can be important to ensure proper surveillance programs, to choose the right therapy and to provide adequate genetic counselling. 


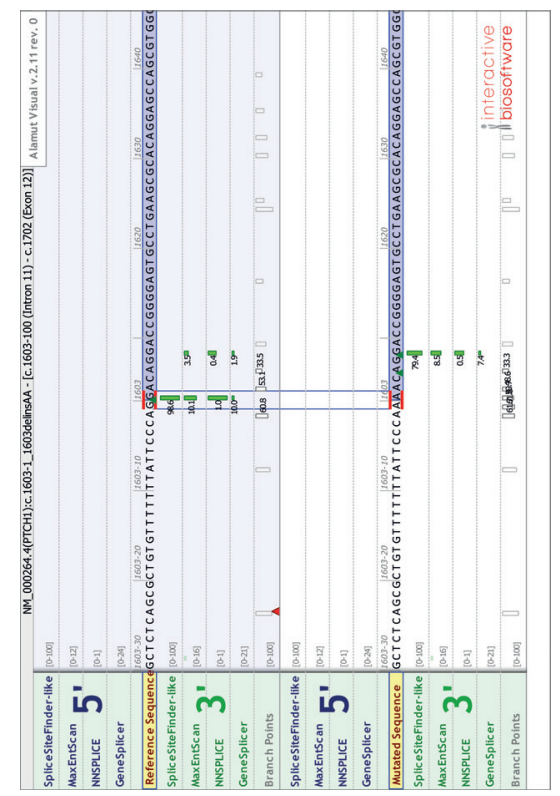

$\infty$

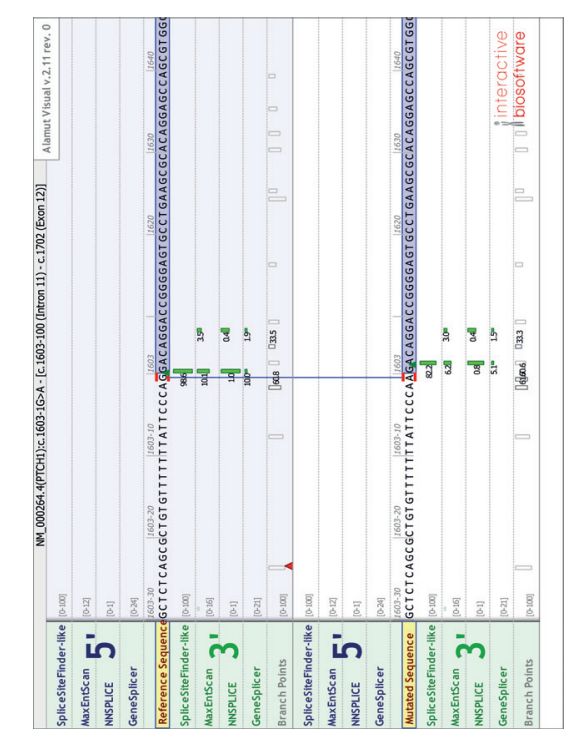

$\varangle$
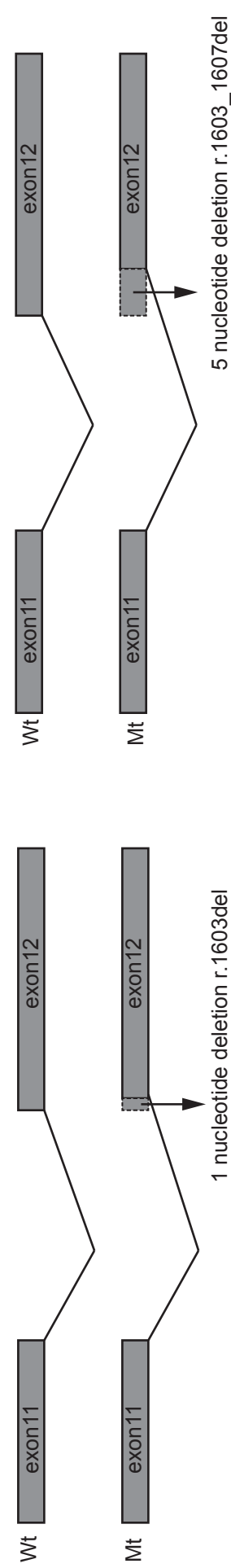

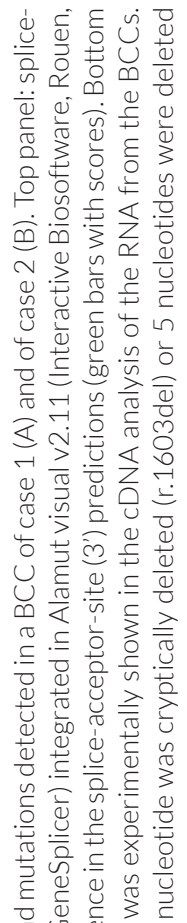

등 可品

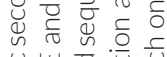

总嵌离

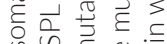

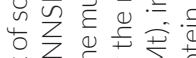

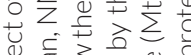

近

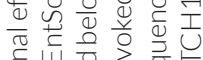

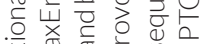

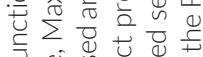

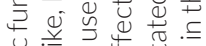

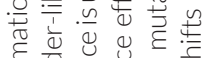

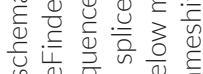

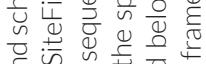

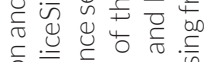

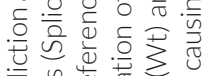

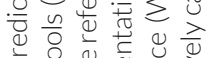

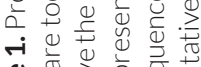

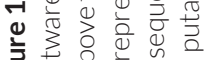

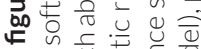

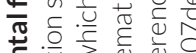

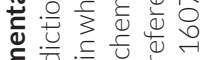

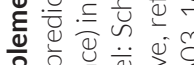

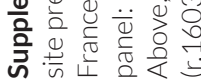




\section{References}

1. John AM, Schwartz RA. Basal cell naevus syndrome: an update on genetics and treatment. Br J Dermatol 2016;174:68-76.

2. Bree AF, Shah MR, Group BC. Consensus statement from the first international colloquium on basal cell nevus syndrome (BCNS). Am J Med Genet A 2011;155A:2091-7.

3. Camisa C, Rossana C, Little L. Naevoid basal-cell carcinoma syndrome with unilateral neoplasms and pits. Br J Dermatol 1985;113:365-7.

4. Gutierrez MM, Mora RG. Nevoid basal cell carcinoma syndrome. A review and case report of a patient with unilateral basal cell nevus syndrome. J Am Acad Dermatol 1986;15:1023-30.

5. Shelley WB, Rawnsley HM, Beerman H. Quadrant distribution of basal cell nevi. Arch Dermatol 1969;100:741-3.

6. Reinders MG, Boersma HJ, Leter EM, et al. Postzygotic mosaicism in basal cell naevus syndrome. Br J Dermatol 2016. British Journal of Dermatology

7. Khamaysi Z, Bochner R, Indelman M, et al. Segmental basal cell naevus syndrome caused by an activating mutation in smoothened. Br J Dermatol 2016;175:178-81.

8. Happle R, Tinschert S. Happle-Tinschert syndrome can be caused by a mosaic SMO mutation and is suggested to be a variant of Curry-Jones syndrome. Br J Dermatol 2016;175:1108.

9. Zenker M, Tinschert S, Wieland I, Schanze D, Happle R. A Postzygotic SMO Mutation Caused the Original Case of Happle-Tinschert Syndrome. Acta Derm Venereol 2018;98:534-5.

10. Torrelo A, Hernandez-Martin A, Bueno E, et al. Molecular evidence of type 2 mosaicism in Gorlin syndrome. Br J Dermatol 2013;169:1342-5.

11. Toberer F, Happle R, Schneiderbauer R, et al. At first sight or second glance: clinical presentation of mosaic manifestations of autosomal dominant skin disorders - a case series. J Eur Acad Dermatol Venereol 2017.

12. Happle R. Mosaicism in human skin: Understanding nevi, nevoid skin disorders, and cutaneous neoplasia. Berlin: Springer; 2014. 



\section{Part two}

Treatment of locally advanced and metastatic basal cell carcinoma with vismodegib 



\title{
Chapter 6
}

\author{
Vismodegib in metastasised \\ basal cell carcinoma
}

Reinders MG, Dirix L, Mosterd K, van Doorn R. 


\section{Abstract}

Background The majority of basal cell carcinomas is easy to cure with surgery or non-invasive treatments. However, large and long-standing tumours can be locally very destructive and in rare cases even metastasise. Hedgehog pathway inhibitors such as vismodegib constitute a new and promising therapy for metastatic or locally advanced basal cell carcinoma.

Case description We describe a patient with metastasised basal cell carcinoma and basal cell naevus syndrome who, in the context of a study, was successfully treated with vismodegib. The main undesirable effects in our patient were muscle cramps, loss of taste, nausea and hair loss.

Conclusion Basal cell carcinoma is potentially a locally destructive skin tumour that only very rarely metastasises. Hedgehog pathway inhibitors such as vismodegib can be administered in a selected group of patients with basal cell carcinoma. 


\section{Inleiding}

Het basaalcelcarcinoom is de meest voorkomende vorm van huidkanker en bij de meeste patiënten eenvoudig curatief te behandelen. Chirurgische behandeling heeft de voorkeur, maar ook fotodynamische therapie, fluorouracil- of imiquimodcrème en radiotherapie worden toegepast. Hoewel het basaalcelcarcinoom langzaam groeit, kunnen grote, lang bestaande tumoren lokaal zeer destructief zijn en in zeldzame gevallen zelfs metastaseren. Een nieuwe, veelbelovende behandeling bij patiënten met gemetastaseerde of niet-resectabele basaalcelcarcinoom is de groep van 'hedgehog'-signaaltransductieremmers, waar vismodegib deel van uit maakt. Wij beschrijven een patiënt met gemetastaseerd basaalcelcarcinoom én het basaalcelnaevussyndroom die in studieverband behandeld werd met vismodegib.

\section{Ziektegeschiedenis}

Patiënt A, een 54-jarige vrouw, bezocht de polikliniek Dermatologie met een grote tumor op de behaarde hoofdhuid (Figuur 1). Haar medische voorgeschiedenis vermeldde het basaalcelnaevussyndroom, waarvoor zij in verschillende ziekenhuizen behandeld was. Ruim 10 jaar geleden was bij haar al eens een basaalcelcarcinoom op de behaarde hoofdhuid geëxcideerd; enkele jaren later had zij er een recidief ontwikkeld, waarvoor zij micrografische chirurgie volgens Mohs had ondergaan. Ook elders op het lichaam waren basaalcelcarcinomen geëxcideerd of behandeld met 5-fluorouracilcrème. De laatste jaren had zij echter het zorgcircuit gemeden. Bij lichamelijk onderzoek zagen wij verspreid over haar lichaam nog tientallen basaalcelcarcinomen (Figuur 2).

Histopathologisch onderzoek van de tumor op de hoofdhuid toonde het beeld van een basaalcelcarcinoom met een sprieterige groeiwijze. Een CT- (Figuur 3) en een MRI-scan van het hoofd lieten zien dat de tumor doorgroeide tot in het schedelbot, mogelijk met invasie van de dura. Een cytologische punctie van een vergrote lymfeklier rechts in de hals was positief voor een niet-kleincellig carcinoom, passend bij een metastase van het basaalcelcarcinoom.

Tijdens een multidisciplinaire oncologiebespreking werd besloten tot resectie van de tumor met verwijdering van het onderliggende schedelbot en lymfeklierdissectie van de betrokken halsregio. Peroperatief bleek echter dat de dura uitgebreid geïnvadeerd was, waardoor radicale resectie van de tumor niet mogelijk was. De hals bevatte 4 lymfeklieren die positief waren voor metastasen van het basaalcelcarcinoom. Omdat de prognose van patiënten met gemetastaseerd basaalcelcarcinoom ondanks behandeling met conventionele cytostatica slecht is, werd bij patiënte gezocht naar een behandelalternatief. In studieverband kon zij behandeld worden met een hedgehog-signaaltransductieremmer, vismodegib, waarvan op dat moment de eerste gunstige resultaten bij patiënten met gemetastaseerd basaalcelcarcinoom waren gepubliceerd. ${ }^{1,2}$ Tijdens de laatste poliklinische controle gebruikte patiënte het medicijn bijna 
3 jaar in een dosering van 150 mg per dag, met als resultaat complete remissie van zowel het lokale tumorresidu ter plaatse van de dura als van de metastasen; al na 6 weken trad regressie op van de tientallen basaalcelcarcinomen elders op het lichaam (Figuur 4). De belangrijkste bijwerkingen bij patiënte zijn spierkrampen, smaakverlies, misselijkheid en haaruitval.

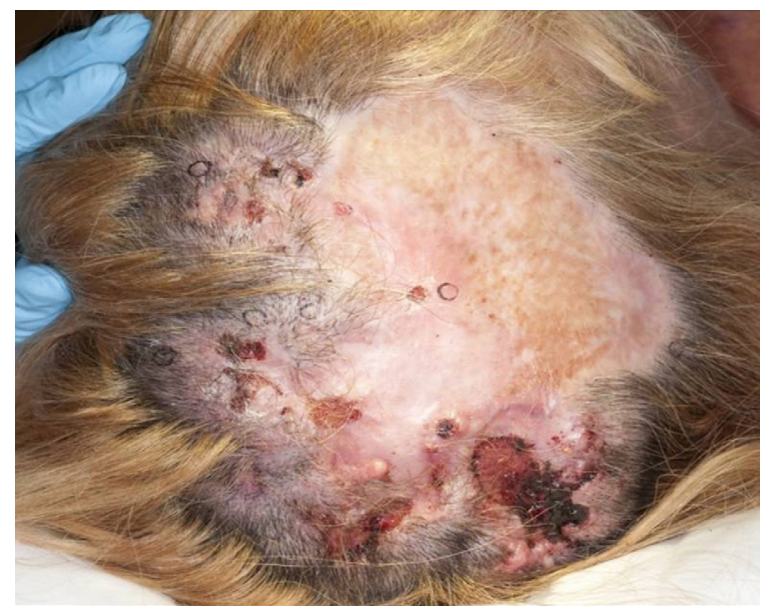

Figuur 1. Foto van patiënt A met op de vertex multipele, ulcererende tumoren die zich bevinden in de randen van een huidtransplantaat.

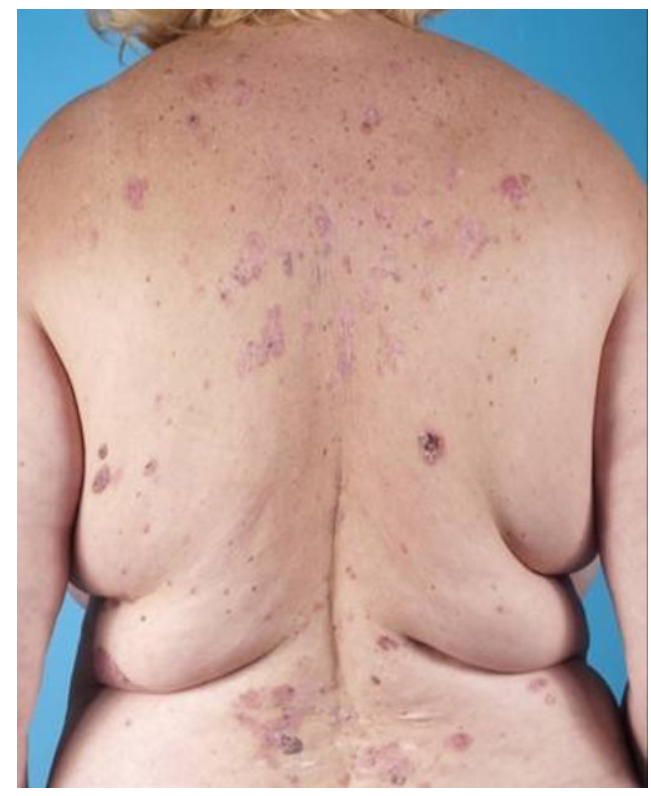

Figuur 2. Foto van patiënt A met verspreid over het lichaam multipele basaalcelcarcinomen in het kader van het basaalcelnaevussyndroom. 


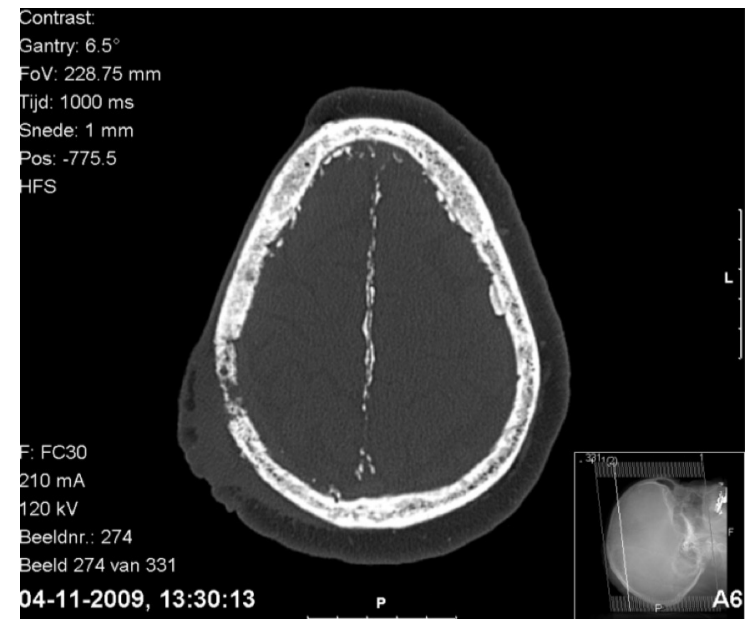

Figuur 3. CT-schedel met aantasting van schedelbot.

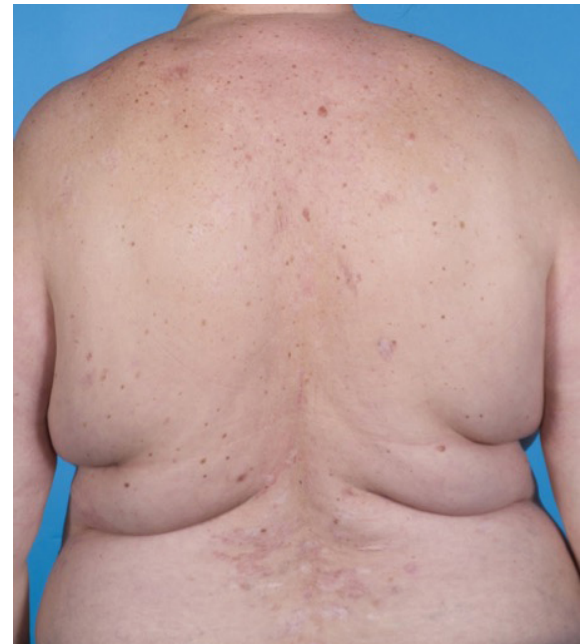

Figuur 4. Foto van patiënt A met regressie van de basaalcelcarcinomen na 3 jaar behandeling met vismodegib. 


\section{Beschouwing}

Het basaalcelcarcinoom is de meest voorkomende vorm van huidkanker, een vorm die uiterst zelden (0,003-0,55\%) metastaseert. In geval van metastasering gaat het meestal om grote (diameter $>10 \mathrm{~cm}$ ), lang bestaande tumoren in het hoofdhalsgebied of in het genitale gebied. Metastasering vindt voornamelijk plaats naar lymfeklieren, Iongen en lever. De prognose is slecht, met een mediane overleving van 8-14 maanden. ${ }^{3}$ Naar de behandeling van gemetastaseerd basaalcelcarcinoom met radiotherapie en conventionele chemotherapie zijn geen prospectieve studies gedaan. Wel zijn er casussen beschreven van patiënten die succesvol behandeld zijn met cisplatine. ${ }^{3}$

\section{Basaalcelnaevussyndroom}

Basaalcelcarcinomen kunnen voorkomen in het kader van het basaalcelnaevussyndroom. Dit is een zeldzame, autosomaal dominant overervende aandoening met een incidentie van 1 per 57.000 personen. Aan dit syndroom ligt een kiembaanmutatie ten grondslag in het patched-1 (PTCH1) tumorsuppressorgen, dat gelegen is op chromosoom 9q22. De belangrijkste klinische symptomen bij patiënten met dit syndroom zijn multipele basaalcelcarcinomen, odontogene keratocysten van de kaak, palmoplantaire huidputjes, calcificatie van de falx cerebri en ribafwijkingen. Patiënten kunnen tevens typische uiterlijke kenmerken hebben, zoals macrocefalie en 'frontal bossing. Daarnaast hebben zij een verhoogd risico op het ontwikkelen van een medulloblastoom. Vaak al op jonge leeftijd ontstaan multipele basaalcelcarcinomen. De behandeling van deze talrijke tumoren kan zeer complex zijn. Radiotherapie is gecontraindiceerd, aangezien het een snelle inductie van nieuwe tumoren kan veroorzaken., ${ }^{4,5}$

\section{Hedgehog-signaaltransductieremmers}

Een nieuwe ontwikkeling voor de behandeling van patiënten met een gemetastaseerd of niet-resectabel basaalcelcarcinoom zijn remmers van de hedgehog-signaaltransductieroute, waartoe onder andere vismodegib en erismodegib behoren. Deze signaaltransductieroute is van belang in de embryogenese en is bij volwassenen voornamelijk actief in stamcellen. Extracellulaire hedgehog-eiwitten fungeren als ligand voor het PTCH1-transmembraaneiwit, een tumorsuppressoreiwit dat normaal gesproken het smoothened (SMO) eiwit remt. In vrijwel alle basaalcelcarcinomen worden inactiverende mutaties in het PTCH1-eiwit of activerende mutaties in het SMO-eiwit gevonden; beide resulteren in verhoogde activiteit van de hedgehog-signaaltransductieroute. ${ }^{6}$ Dit leidt tot een toename van celproliferatie en tot tumorvorming. Hedgehog-signaaltransductieremmers kunnen op verschillende manieren de signaaltransductieroute beïnvloeden; vismodegib en erismodegib activeren beide het $\mathrm{SMO}$-eiwit. Vismodegib wordt oraal toegediend, van erismodegib is ook een topicale vorm beschreven.? 


\section{Vismodegib}

De studie waaraan onze patiënte deelnam laat bij 30\% van de patiënten met gemetastaseerd basaalcelcarcinoom en bij $43 \%$ van de patiënten met lokaal uitgebreide basaalcelcarcinomen een gedeeltelijke of complete respons zien door gebruik van vismodegib. De meest gerapporteerde bijwerkingen van het medicijn zijn spierkrampen, smaakstoornissen, gewichtsverlies, vermoeidheid, misselijkheid en haaruitval. ${ }^{8}$ Secundaire resistentie is eveneens beschreven, waarbij na een initiële respons de tumor alsnog recidiveert. ${ }^{9}$ Ook zijn er resultaten bekend van vismodegib bij patiënten met het basaalcelnaevussyndroom. ${ }^{10}$ Deze patiënten ontwikkelden significant minder nieuwe basaalcelcarcinomen en bij hen gingen bestaande basaalcelcarcinomen in regressie. Deze positieve resultaten kunnen waarschijnlijk verklaard worden door de aanwezigheid van een kiembaanmutatie in het PTCH1-tumorsuppressorgen. 2,10 Vismodegib is in de Verenigde Staten geregistreerd voor gemetastaseerd en lokaal uitgebreid basaalcelcarcinoom waarbij chirurgische of radiotherapeutische behandeling niet mogelijk is. Naar verwachting zal de registratie van vismodegib in Europa nog dit jaar plaatsvinden. In verschillende academische centra in Nederland worden op dit moment studies uitgevoerd met hedgehog-signaaltransductieremmers 


\section{Conclusie}

Onze casus is een voorbeeld van een patiënt met een zeldzame, agressieve presentatie van het veel voorkomende basaalcelcarcinoom. De casus is illustratief voor de effectiviteit van een nieuwe, veelbelovende groep van geneesmiddelen die zich richt op de remming van de hedgehog-signaaltransductieroute. 


\section{Referenties}

1. Von Hoff DD, LoRusso PM, Rudin CM, et al. Hedgehog pathway inhibition in advanced basal-cell carcinoma. N Engl J Med. 2009;361:1164-72

2. Goldberg LH, Firoz BF, Weiss GJ, Blaydorn L, Jameson G, Von Hoff DD. Basal cell naevus syndrome: a brave new world. Arch Dermatol. 2010;146:17-9

3. Walling HW, Fosko SW, Geraminejad PA, Whitaker DC, Arpey CJ. Aggressive basal cell carcinoma: presentation, pathogenesis, and management. Cancer Metastasis Rev. 2004;23:389-402

4. De Meij TG, Baars MJ, Gille JJ, Hack WW, Haasnoot K, van Hagen JM. Van gen naar ziekte; basaalcelnaevussyndroom. Ned Tijdschr Geneeskd. 2005;149:78-81.

5. Van der Geer S, Ostertag JU, Krekels GA. Treatment of basal cell carcinomas in patients with nevoid basal cell carcinoma syndrome. J Eur Acad Dermatol Venereol. 2009;23:308-13

6. Göppner D, Leverkus M. Basal cell carcinoma: from the molecular understanding of the pathogenesis to targeted therapy of progressive disease. J Skin Cancer. 2011;2011:650258.

7. Skvara H, Kalthoff F, Meingassner JG, et al. Topical treatment of basal cell carcinomas in nevoid basal cell carcinoma syndrome with a smoothened inhibitor. J Invest Dermatol. 2011;131:1735-44 8

8. Sekulic A, Migden MR, Oro AE, Dirix L, Lewis KD, Hainsworth JD. Efficacy and safety of vismodegib in advanced basal-cell carcinoma. N Engl J Med. 2012;366:2171-9

9. Chang AL, Oro AE. Initial assessment of tumor regrowth after vismodegib in advanced basal cell carcinoma. Arch Dermatol. 2012;148:1324-5.

10. Tang JY, Mackay-Wiggan JM, Aszterbaum M, et al. Inhibiting the hedgehog pathway in patients with the basal-cell nevus syndrome. N Engl J Med. 2012;366:2180-8 



\section{Chapter 7}

Vismodegib for basal cell carcinoma: targeted therapy in case of locally advanced or metastasised disease

Reinders MG, Terra JB, Reyners AK, Aarts MJ, de Haas ER, Mosterd K 


\section{Abstract}

The development of the hedgehog pathway inhibitor vismodegib provides a new treatment option for metastasised and locally advanced basal cell carcinoma in which surgical excision or radiotherapy is contraindicated. Only a fraction of patients with basal cell carcinoma are eligible for this therapy, but it is effective in the majority of those who do receive vismodegib. However, development of tumour resistance is quite common and adverse events frequently lead to discontinuation of therapy. Intermittent treatment or combination therapy could reduce the occurrence of tumour resistance and diminish toxicity. We present three patients who were successfully treated with vismodegib: a 73-year-old man with locally advanced basal cell carcinoma, an 82-year-old man with basal cell carcinoma that had metastasised to the lungs, and a 42-year-old man with Gorlin syndrome. 


\section{Inleiding}

Het basaalcelcarcinoom is de meest voorkomende vorm van kanker in Nederland, met 37.500 nieuwe patiënten in 2014, en de incidentie stijgt nog steeds. ${ }^{1}$ Het overgrote deel van de basaalcelcarcinomen is eenvoudig curatief te behandelen. De behandeling van voorkeur is excisie. Voor oppervlakkig groeiende basaalcelcarcinomen zijn daarnaast non-invasieve therapieën zoals 5-fluorouracilcrème, imiquimodcrème en fotodynamische therapie beschikbaar. In specifieke gevallen is radiotherapie geïndiceerd. Langer bestaande onbehandelde laesies kunnen leiden tot een zogenaamd lokaal uitgebreid basaalcelcarcinoom. Curatieve behandeling met chirurgie of radiotherapie is bij deze tumoren soms technisch niet meer mogelijk of heeft grote functionele gevolgen. Metastasering is uiterst zeldzaam (0,003-0,55\%) en komt voornamelijk voor bij lokaal uitgebreide basaalcelcarcinomen in het hoofd-hals gebied of genitale gebied. De mediane overleving bij gemetastaseerde ziekte is 8 tot 14 maanden. ${ }^{2}$ De meerwaarde van radiotherapie of conventionele chemotherapie bij gemetastaseerd basaalcelcarcinoom is tot nu toe niet aangetoond. De komst van 'targeted therapy' ofwel doelgerichte systemische therapie met 'hedgehog' (Hh)- signaaltransductieremmers heeft gezorgd voor nieuwe mogelijkheden in de behandeling van deze vergevorderde en gemetastaseerde basaalcelcarcinomen. In Nederland is nu vier jaar ervaring met de Hh-remmer vismodegib. In eerste instantie werd deze behandeling enkel gegeven in studieverband. Sinds 2014 is vismodegib in Nederland geregistreerd voor volwassenen met lokaal uitgebreid en/of gemetastaseerd basaalcelcarcinoom dat ongeschikt is voor operatief ingrijpen of radiotherapie en wordt het in de reguliere patiëntenzorg voorgeschreven in een aantal academische centra. Tumoren bevinden zich vaak in het hoofdhalsgebied en indicatiestelling van systeemtherapie vindt dan ook bij voorkeur plaats in een multidisciplinair hoofd-halsteam, waarin onder andere een dermatoloog, hoofd-hals chirurg, radiotherapeut en internist-oncoloog participeren. Het aantal patiënten dat in ons land jaarlijks in aanmerking komt voor behandeling met Hh-remmers is klein. Centralisatie van zorg lijkt dan ook wenselijk. In 2015 werden in Nederland 25 patiënten behandeld, waarvan een groot deel slechts kortdurend of in studieverband. De kosten van behandeling met vismodegib bedragen ongeveer 60.000 euro per jaar. Vanuit de Nederlandse Vereniging van Dermatologie en Venereologie is een landelijke stuurgroep opgericht, met het doel een platform te creëren voor overleg en kwaliteitsbewaking bij alle patiënten die in Nederland worden behandeld.

Wij beschrijven drie patiënten die met vismodegib behandeld werden voor respectievelijk een lokaal uitgebreid basaalcelcarcinoom, een gemetastaseerd basaalcelcarcinoom en multipele basaalcelcarcinomen in het kader van het basaalcelnaevussyndroom. Aan de hand van deze casuïstiek bespreken wij de werking en bijwerkingen van vismodegib en de nieuwe ontwikkelingen rondom dit geneesmiddel. 


\section{Ziektegeschiedenissen}

\section{Patiënt A}

Een 73-jarige man met een blanco voorgeschiedenis werd verwezen met een sinds vijftien jaar bestaand basaalcelcarcinoom op zijn voorhoofd, waarvoor hij nooit eerder medische hulp had gezocht (Figuur 1A). Een CT- en MRI-scan lieten destructie zien van de voorwand van de sinus frontalis en uitbreiding van de tumor in beide mediale ooghoeken. Curatieve chirurgie of radiotherapie zouden blindheid tot gevolg kunnen hebben. In verband met wondverzorgingsproblemen en dreigend visusverlies door tumorprogressie, werd gekozen voor behandeling met vismodegib 150 mg per dag. Na 5 maanden behandeling zagen we een complete klinische respons (Figuur 1B). Patiënt wordt inmiddels ruim een jaar continu behandeld met vismodegib met een aanhoudende complete respons. Zijn voornaamste bijwerkingen zijn spierkrampen, haaruitval en gewichtsverlies van ongeveer $5 \mathrm{~kg}$.
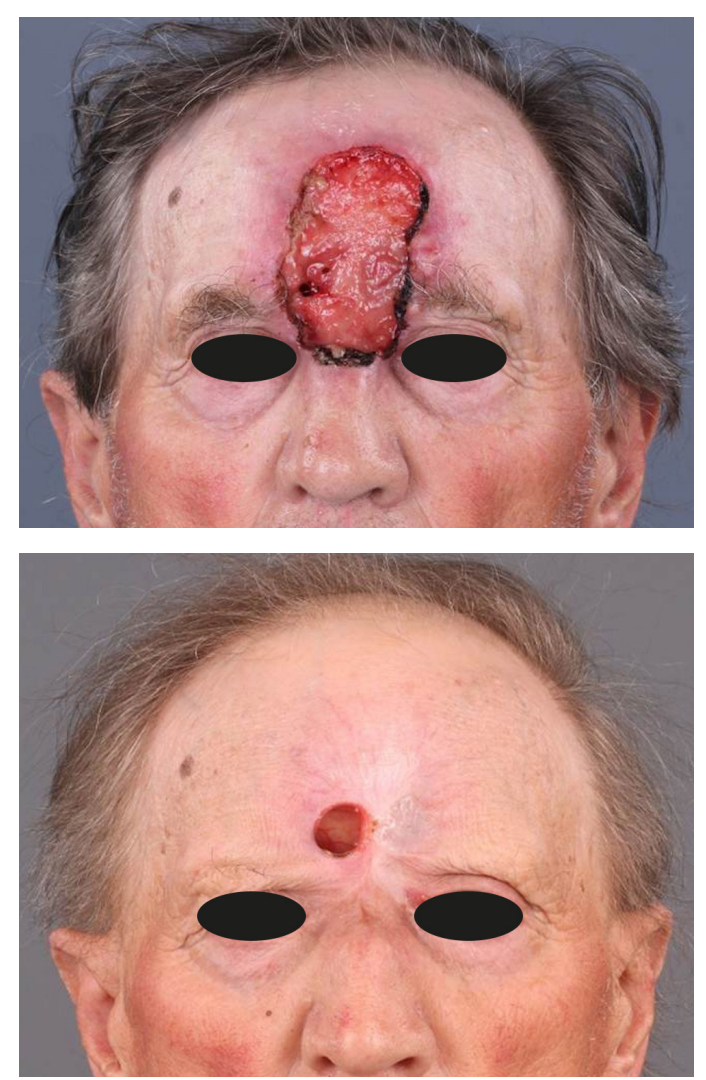

Figuur 1A. Aangezicht van patiënt A met een lokaal uitgebreid basaalcelcarcinoom op zijn voorhoofd. Centraal is een defect van de voorwand van de sinus frontalis zichtbaar. B. Aanhoudende klinische respons na 1 jaar behandeling met vismodegib. 


\section{Patiënt B}

Een 82-jarige man bezocht ons spreekuur met een sinds twaalf jaar bestaand ulcererend en makkelijk bloedend basaalcelcarcinoom op de scalp (Figuur 2A). Uit angst zocht patiënt niet eerder medische hulp. Een CT-hoofd-hals liet een zeer uitgebreid weke delen proces van de hoofdhuid zien, verlopend van de kruin rechts tot retro-auriculair met lokaal botaantasting tot en met de tabula interna. Daarnaast waren op een CT-thorax uitgebreide nodulaire afwijkingen in de longen zichtbaar, tot ruim $2 \mathrm{~cm}$ groot, suspect voor pulmonale metastasen (Figuur 2B). Anamnestisch, bij lichamelijk onderzoek, laboratoriumonderzoek en op de eerdergenoemde beeldvorming waren geen aanwijzingen voor een andere primaire tumor. Gezien de lokale uitgebreidheid en de verdenking op pulmonale metastasen, werd gestart met vismodegib 150 mg per dag. Na 9 maanden behandeling zagen we duidelijke regressie van de tumor op de scalp (Figuur 2C) en volgens RECIST 1.1 stabiele ziekte (afname van 19\% in de diameter) van de pulmonale metastasen. De voornaamste bijwerkingen zijn smaak- en eetlustverlies, partieel haarverlies en gewichtsverlies van $5 \mathrm{~kg}$. 


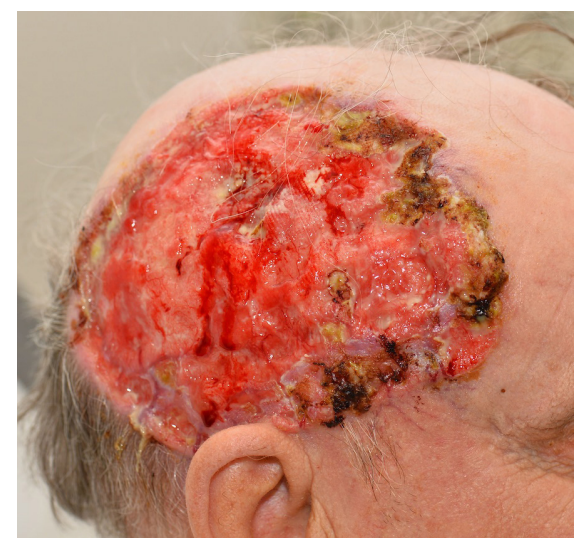

Figuur 2A. Patient B met een lokaal uitgebreid basaalcelcarcinoom van de hoofdhuid met doorgoei in het schedelbot.

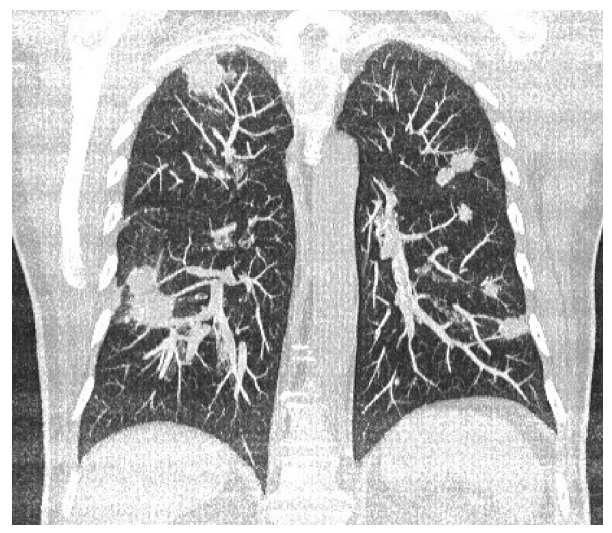
thoracale aorta (pars descendens)

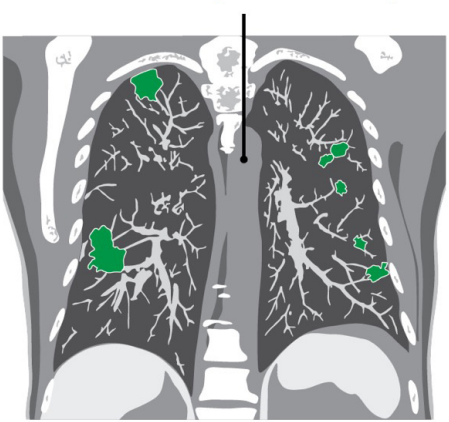

nodulaire afwijking

Figuur 2B. Axiale CT-opname met 'maximum intensity projection' van de thorax met multipele noduaire afwijkingen, passend bij pulmonaire metastasen.

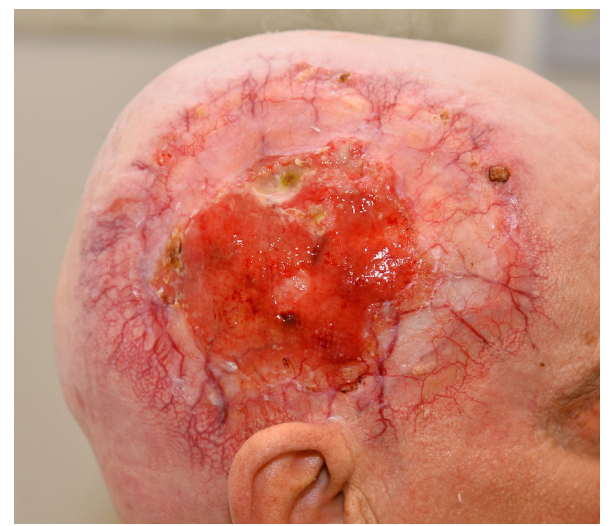

Figuur 2C Regressie van de huidtumor na 9 maanden behandeling met vismodegib. 


\section{Patiënt C}

Een 42-jarige man met het basaalcelnaevussyndroom kwam regelmatig voor oncologische controle op de polikliniek dermatologie. In het kader van dit syndroom was hij bekend met hydrocefalus, hypoplasie van het corpus callosum, mentale retardatie, skeletdeformaties aan handen en voeten, cheilognathopalatoschisis, odontogene keratocysten en multipele basaalcelcarcinomen. Patiënt woont in een instelling en wordt vertegenwoordigd door zijn zus. Patiënt heeft een honderdtal basaalcelcarcinomen gehad, welke meestal operatief verwijderd werden onder algehele anesthesie. Daarnaast werd herhaaldelijk non-invasieve topicale behandeling toegepast met 5-fluourouracil- en imiquimodcrème. De behandelingen waren voor patiënt zeer belastend en na chirurgie ontstonden jeukende keloïden. Nadat er in 3 maanden tijd meer dan twintig nieuwe basaalcelcarcinomen optraden, werd gestart met vismodegib 150 mg per dag. Met het oog op de bijwerkingen werd gekozen voor intermitterende behandeling. Tijdens een behandelperiode van 3 maanden trad er een snelle en complete respons op van alle aanwezige tumoren. Behoudens gewichtsverlies van $5 \mathrm{~kg}$ had patiënt geen bijwerkingen. Inmiddels is vismodegib 6 maanden gestaakt en de tumoren komen langzaam terug. 


\section{Beschouwing}

\section{Werkingsmechanisme}

De Hh-signaaltransductieroute is van belang in de embryogenese en is daarna betrokken bij stamcelonderhoud en weefselhomeostase. Extracellulaire Hh-eiwitten fungeren als ligand voor het patched-1 (PTCH1) transmembraaneiwit, een tumorsuppressoreiwit, dat normaal gesproken het oncogene smoothened (SMO) eiwit remt. Ongeveer 90\% van de sporadische basaalcelcarcinomen heeft identificeerbare mutaties in PTCH1 en 10\% heeft activerende mutaties in SMO, beide leidend tot een verhoogde activiteit van de Hh-signaaltransductieroute. Dit heeft een toename van celproliferatie en tumorvorming tot gevolg. De werking van vismodegib berust op binding aan het SMO-eiwit, waardoor de Hh-signaaltransductieroute geremd wordt. ${ }^{3}$

\section{Effectiviteit}

Recent zijn de interim-resultaten van de STEVIE-studie gepubliceerd. Dit is het grootste onderzoek naar de veiligheid en effectiviteit van vismodegib, waarin 1277 patiënten met lokaal uitgebreid of gemetastaseerd basaalcelcarcinoom behandeld werden. Op het moment van analyse werden 499 patiënten een jaar gevolgd. Van de patiënten met lokaal uitgebreid basaalcelcarcinoom was de best gemeten respons bij 34\% een complete respons bij 34\% ( $n=153)$, bij 33\% een partiële respons ( $n=149)$ en stabiele ziekte bij 27\% ( $n=118)$. Progressieve ziekte was de best gemeten respons bij $2 \%$ van de patiënten. De mediane progressievrije ziekteduur was 24 maanden. Bij gemetastaseerd basaalcelcarcinoom was de effectiviteit lager. In de STEVIE-studie had 7\% ( $n=2)$ van de patiënten met metastasen een complete respons, 31\% ( $n=9)$ een partiële respons en 34\% ( $n=10)$ stabiele ziekte. Progressieve ziekte vond plaats in $4 \%$ van de patiënten. De mediane progressievrije ziekteduur was 13 maanden. ${ }^{4}$

\section{Bijwerkingen}

Vrijwel alle patiënten die behandeld worden met vismodegib ervaren tenminste één bijwerking. De meest voorkomende bijwerkingen, bij ongeveer 50\% van de patiënten, zijn spierspasmen, haar- en smaakverlies. Gewichtsverlies komt in 33\% van de patiënten voor en zou gerelateerd kunnen zijn aan de smaakverandering, maar is waarschijnlijk ook te wijten aan een probleem in de vetopslag ten gevolge van de medicatie. Diarree, misselijkheid en vermoeidheid zijn andere veel voorkomende bijwerkingen. De ontwikkeling van cutane plaveiselcelcarcinomen, zowel in het tumorgebied als daarbuiten, is eveneens een gerapporteerde bijwerking. ${ }^{5}$ Derhalve is frequente dermatologische controle geïndiceerd en dient laagdrempelig histologisch onderzoek plaats te vinden in geval van verdachte huidafwijkingen. 'Serious adverse events', waaronder pneumonie, algehele gezondheidsachteruitgang en dehydratie, werden in de STEVIE-studie gerapporteerd bij $22 \%$ van de patiënten. Ongeveer $40 \%$ van de patiënten is vanwege bijwerkingen gestopt met 
de behandeling. De gemiddelde behandelduur was 8,5 maanden. ${ }^{4}$ Goede begeleiding van de patiënt is dan ook essentieel en consultatie van een diëtiste ter voorkoming van gewichtsverlies kan nodig zijn.

\section{Resistentie}

Een deel van de basaalcelcarcinomen reageert niet of slechts gedeeltelijk op behandeling met vismodegib. Deze basaalcelcarcinomen hebben mogelijk een ander genetisch profiel dan de tumoren met een goede klinische respons. De tumoren die wel reageren hebben een gemiddelde responsduur van 24 maanden. ${ }^{4}$ Activerende SMO mutaties in de tumor, die voorkómen dat vismodegib kan binden, liggen ten grondslag aan deze zogenoemde secundaire resistentie. ${ }^{6,7}$ Deze mutaties zouden pre-existent aanwezig kunnen zijn; cellen met deze mutaties overleven behandeling en groeien uit tot (nieuwe) resistente tumoren. Een andere mogelijkheid is dat de mutaties ontstaan tijdens de behandeling. Als behandelstrategie ter voorkoming van resistentie biedt intermitterend gebruik of combinatiebehandeling met andere middelen mogelijk een uitkomst.

\section{Neoadjuvante behandeling}

Het is nog onduidelijk of neoadjuvante behandeling van basaalcelcarcinomen met vismodegib zinvol is. Terughoudendheid is gewenst, aangezien de behandeling er voor kan zorgen dat de tumor niet meer per continuitatem groeit, waardoor snijrandonderzoek naar radicaliteit onbetrouwbaar wordt. ${ }^{8}$ Daarnaast zijn er sterke aanwijzingen dat tijdens behandeling met vismodegib indolente tumorcellen achterblijven, die na behandeling weer klinisch manifest worden. ${ }^{6,7}$ Dit betekent dat voor radicale resectie het gehele in eerste instantie aangedane gebied moet worden verwijderd. Een andere behandelingsmogelijkheid is de combinatie van radiotherapie en vismodegib. Dit lijkt effectief en goed verdraagbaar, maar de resultaten van een fase 2 studie volgen nog.

\section{Basaalcelnaevussyndroom}

Het basaalcelnaevussyndroom (BCNS), ook wel bekend als Gorlin syndroom, is een autosomaal dominant overervende aandoening met een incidentie van 1 per 57.000 personen. Een kiembaanmutatie in het PTCH1-gen ligt ten grondslag aan dit syndroom. De belangrijkste klinische verschijnselen van dit syndroom zijn multipele basaalcelcarcinomen op jonge leeftijd, palmoplantaire huidputjes, odontogene keratocysten van de kaak, calcificatie van de falx cerebri, ribafwijkingen, medulloblastoom op kinderleeftijd en typische uiterlijke kenmerken, zoals macrocefalie en 'frontal bossing.' Het aantal en de frequentie van het optreden van nieuwe basaalcelcarcinomen wisselt sterk per individu. De meeste tumoren zijn goed te behandelen met excisie of non-invasieve therapie. De behandeling kan echter complex zijn en de multipele, soms mutilerende, littekens kunnen voor een grote psychische belasting zorgen. Radiotherapie is bij deze aandoening gecontra-indiceerd, aangezien röntgenstraling inductievan 
nieuwe tumoren veroorzaakt. Omdat de oorzaak van BCNS gelegen is in een PTCH1 mutatie, reageren de basaalcelcarcinomen goed op behandeling met Hh-remmers en de ontwikkeling van nieuwe tumoren wordt geremd. ${ }^{10}$ Op dit moment is vismodegib niet geregistreerd voor onderhoudstherapie bij patiënten met BCNS. Voor een selecte groep van patiënten met BCNS is er zeker een plaats voor behandeling met Hh-remmers, deze mening wordt gedeeld door de landelijke stuurgroep. Momenteel worden patiënten met multipele basaalcelcarcinomen met en zonder BCNS in studieverband behandeld met vismodegib in verschillende doseringsschema's. Intermitterend doseren zou de toxiciteit van de behandeling verminderen, waardoor de behandeling beter verdragen wordt. 


\section{Conclusie}

De komst van Hh-remmers, zoals vismodegib, heeft gezorgd voor nieuwe mogelijkheden in de behandeling van het lokaal uitgebreid en/of gemetastaseerd basaalcelcarcinoom dat ongeschikt is voor operatief ingrijpen of radiotherapie. Bij bepaalde patiënten met het basaalcelnaevussyndroom heeft onderhoudstherapie met Hh-remmers een plaats. Bijwerkingen komen relatief vaak voor en zijn frequent een reden om therapie te staken. Aandacht voor deze bijwerkingen en een goede begeleiding van de patiënt zijn belangrijk. Daarnaast is het optreden van resistentie een regelmatig voorkomend probleem. Intermitterende behandeling zou zowel de toxiciteit als de kans op resistentie kunnen verminderen. Behandeling met Hh-remmers vindt bij voorkeur plaats in een multidisciplinair hoofd-hals team en gezien het kleine aantal patiënten dat in aanmerking komt voor deze behandeling is centralisatie van zorg wenselijk. 


\section{Referenties}

1. Flohil SC, Seubring I, van Rossum MM, Coebergh JW, de Vries E, Nijsten T. Trends in Basal cell carcinoma incidence rates: a 37-year Dutch observational study. J Invest Dermatol 2013;133:913-8.

2. Walling HW, Fosko SW, Geraminejad PA, Whitaker DC, Arpey CJ. Aggressive basal cell carcinoma: presentation, pathogenesis, and management. Cancer Metastasis Rev 2004;23:389-402.

3. Epstein EH. Basal cell carcinomas: attack of the hedgehog. Nat Rev Cancer 2008;8:743-54.

4. Basset-Seguin N, Hauschild A, Grob JJ, et al. Vismodegib in patients with advanced basal cell carcinoma (STEVIE): a pre-planned interim analysis of an international, open-label trial. Lancet Oncol 2015;16:729-36.

5. Mohan SV, Chang J, Li S, Henry AS, Wood DJ, Chang AL. Increased Risk of Cutaneous Squamous Cell Carcinoma After Vismodegib Therapy for Basal Cell Carcinoma. JAMA Dermatol 2016;152:527-32.

6. Brinkhuizen T, Reinders MG, van Geel M, et al. Acquired resistance to the Hedgehog pathway inhibitor vismodegib due to smoothened mutations in treatment of locally advanced basal cell carcinoma. J Am Acad Dermatol 2014;71:1005-8.

7. Atwood SX, Sarin KY, Whitson RJ, et al. Smoothened variants explain the majority of drug resistance in basal cell carcinoma. Cancer Cell 2015;27:342-53.

8. Aldabagh B, Yu J, Perkocha LA, Arron S. Histologic changes in basal cell carcinoma after treatment with vismodegib. Dermatol Surg 2013;39:1703-5.

9. de Meij TG, Baars MJ, Gille JJ, Hack WW, Haasnoot K, van Hagen JM. [From gene to disease: basal cell naevus syndrome]. Ned Tijdschr Geneeskd 2005;149:78-81.

10. Tang JY, Mackay-Wiggan JM, Aszterbaum M, et al. Inhibiting the hedgehog pathway in patients with the basal-cell nevus syndrome. N Engl J Med 2012;366:2180-8. 




\section{Chapter 8}

\section{Acquired resistance to the hedgehog pathway inhibitor vismodegib due to smoothened mutations in treatment of locally advanced basal cell carcinoma}

Brinkhuizen T*, Reinders MG*, van Geel M, Hendriksen AJ, Paulussen AD, Winnepenninckx VJ, Keymeulen KB, Soetekouw PM, van Steensel MA, Mosterd K

Journal of the American Academy of Dermatology 2014 Nov

*Both authors contributed equally to this paper and should be considered as first authors. 



\section{Letter to the editor}

Sporadic basal cell carcinoma (BCC) is the most frequent malignancy in Caucasians. It mostly behaves indolently, however when neglected it can become destructive (locally advanced BCC). ${ }^{1}$ Upregulation of Hedgehog (Hh) signalling is crucial in the development of almost all BCCs. ${ }^{2}$ Vismodegib is a synthetic smoothened (SMO) antagonist that inhibits the Hh pathway, with response rates up to $47.6 \%$ in locally advanced $\mathrm{BCC}^{3}$

We saw a 68-year-old woman with a 15-cm wide deeply ulcerating infiltrative BCC on her left shoulder, which initially started as a small asymptomatic red papule that was neglected for 20 years (Figure 1A). Magnetic resonance imaging (MRI) confirmed widespread tumour invasion of the shoulder girdle muscles but no evidence of lymphogenic or visceral metastasis. Because curative surgery and radiation therapy would impair shoulder function and enhance the risk of lymphedema of the arm, we treated our patient with vismodegib 150 mg once daily.

Treatment resulted in dramatic clinical tumour regression within 8 weeks with complete regression and scar tissue remaining after 16 weeks (Figure 1B). After 20 weeks of continuous treatment, multiple nodules became visible in the former tumour area (Figure 1C). MRI showed multifocal tumour recurrence in the skin and underlying muscles. Biopsies of two of the skin nodules revealed infiltrative BCC (Figure $2 \mathrm{~A}-\mathrm{C}$ ). Because of this progressive disease, vismodegib was discontinued and complete surgical excision was performed (week 27).
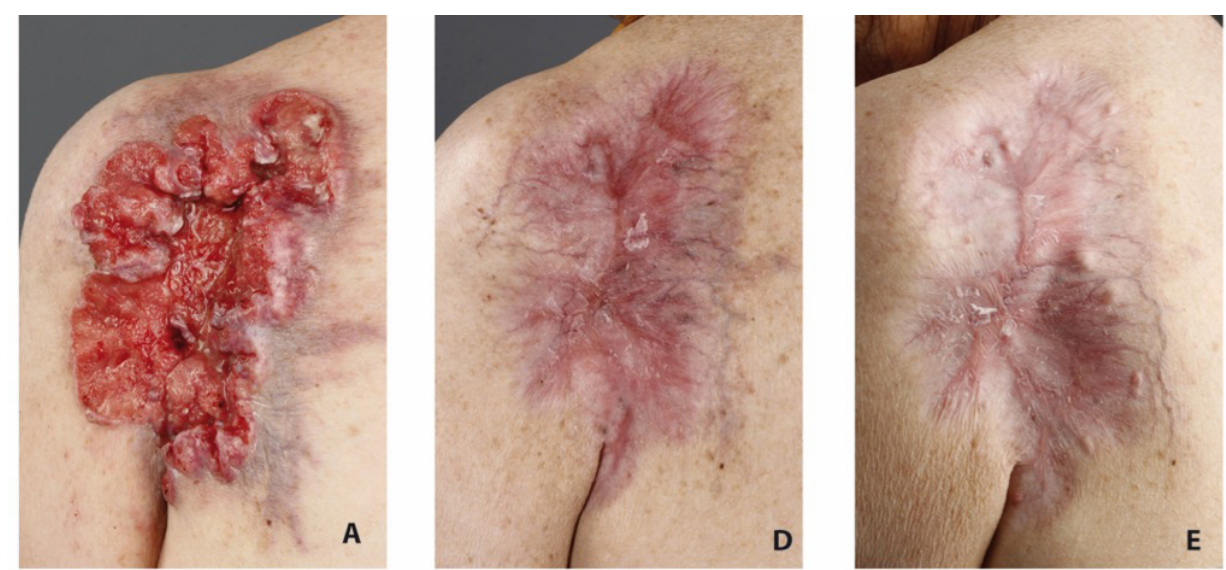

Figure 1. Clinical pictures pre- and posttreatment. A. Basal cell carcinoma (BCC) before treatment with vismodegib. B. Complete clinical response 16 weeks after start of treatment. c. Newly developed tumour nodules, 27 weeks after start of treatment. 

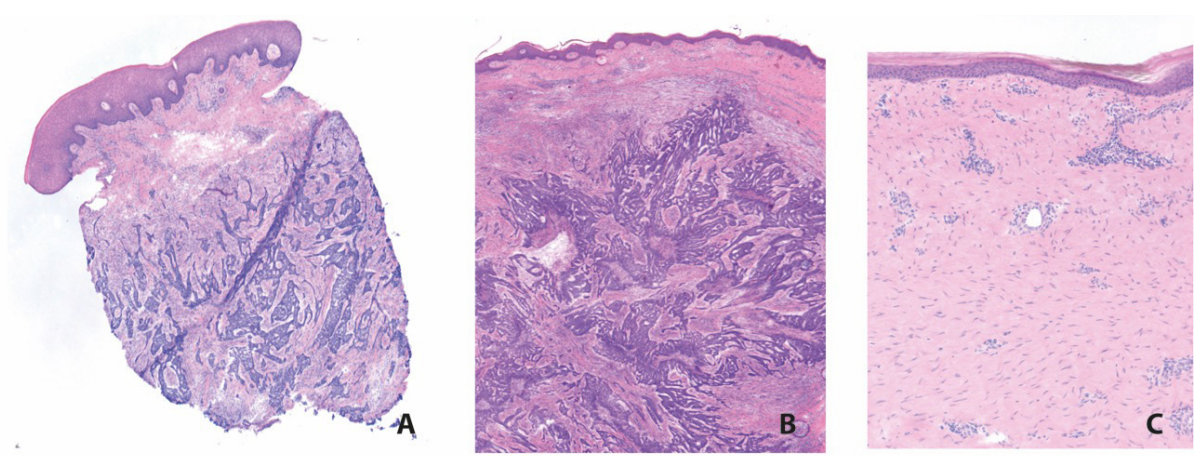

Figure 2. Histologic examination on pretreatment and posttreatment tissue. A. Tumour biopsy before treatment with vismodegib, showing infiltrative palisading basaloid cells reaching into the reticular dermis fitting the diagnosis of BCC. B. Biopsy from newly developed tumour nodule after 27 weeks of treatment with vismodegib, showing infiltrative basal cell carcinoma. C. Biopsy of responding tissue after 27 weeks of vismodegib, showing extensive fibrosis with an increased number of fibroblasts, neovascularization, a sparse lymphocytic infiltrate, but no residual BCC. (A-C Hematoxylin-eosin stain; original magnification 32.5).

To unravel the mechanism of resistance, we performed mutation analysis on pretreatment tumour tissue, and on both responding tissue and recurrent tumour nodules (obtained at the time of surgical excision). With genomic DNA analysis of the PTCH1 coding exons (GenBank RefSeq NM_000264.3) a presumably heterozygous c.1728_1728+1delinsAA (Figure 3a) mutation was found together with loss of heterozygosity in the primary BCC and in the recurrent tumour nodules, indicating that cells from the original tumour had survived. This mutation was not present in DNA isolated from buccal mucosa (saliva) or responding tissue.

Because vismodegib resistance in medulloblastoma is caused by acquired mutations in $\mathrm{SMO},{ }^{4}$ we reasoned that similar mutations might explain resistance in BCCs. We therefore sequenced SMO (GenBank RefSeq NM_005631.4) in two recurrent BCCs and detected two different, novel heterozygous missense SMO mutations (c.842G>T (p.Trp281Leu) in exon 4 and c.961G >A (p.Val321Met) in exon 5) (Figure 3B). These SMO mutations were not found in pretreatment tumour tissue, responding tissue, or buccal mucosa swab (not shown). The presence of 2 different mutations precludes a clonal origin of the resistant BCC nests, supporting tumour heterogeneity, even though they arose from the same clonal primary tumour. Possibly, even more SMO mutations might underlie tumour regrowth in this case, because not all new tumour nodules were biopsied. Our observation suggests that BCC can acquire resistance to vismodegib via different types of SMO mutations. 
Tumour resistance is a challenge in targeted treatment of BCC. Possible approaches to overcome tumour resistance are combination therapy with different small molecule inhibitors, sequential or rotational therapy with nontreatment periods, or alternating different small molecule inhibitors. These approaches may lead to synergistic therapeutic effects, a lower application dosage, and even prevention of (acquired) tumour resistance. Experience with targeted therapy for melanoma has already shown that combination of different agents leads to a delay in development of tumour resistance. ${ }^{5}$ In vismodegib treated BCC, other SMO inhibitors, such as itraconazole and arsenic trioxide, are possible drug candidates for this strategy. In the future, mutational analysis on pretreatment and recurrent tumour tissue may contribute to anticipating the type of resistance, in order to proactively alter therapy and customize treatment of both patient and tumour characteristics.

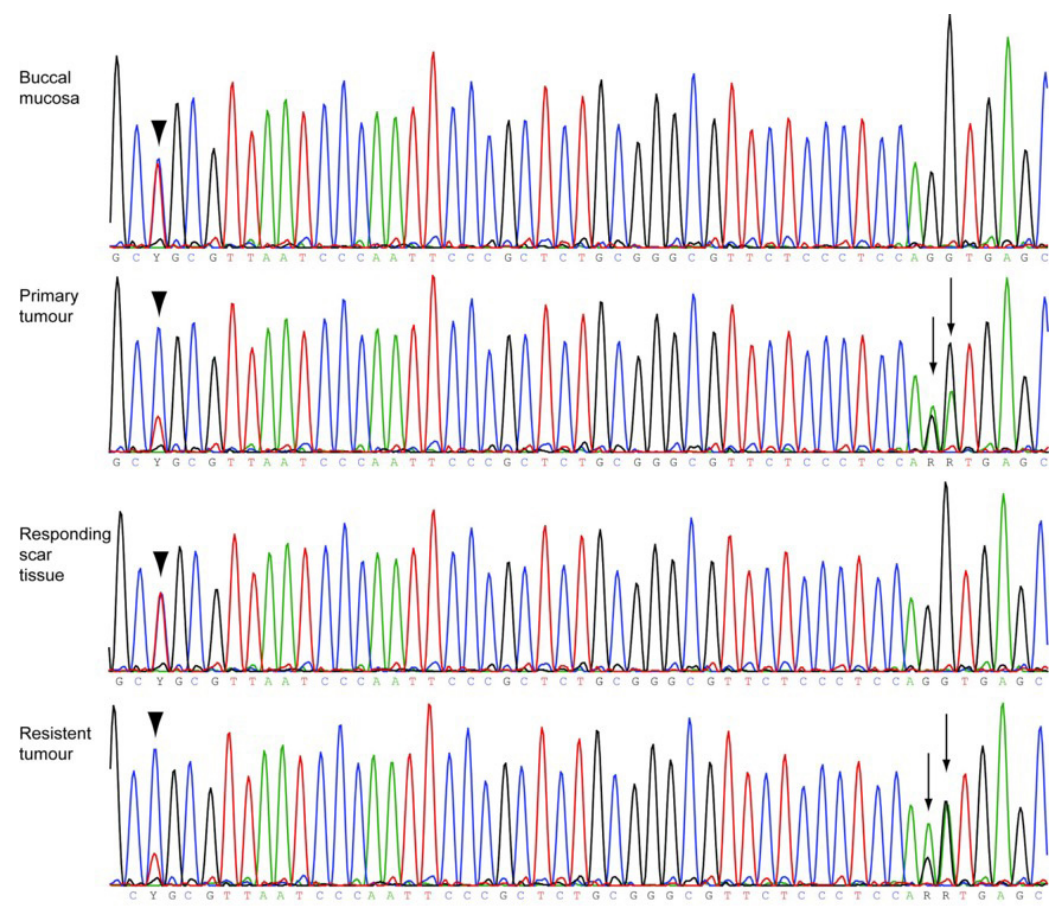

Figure 3. Genomic analysis of PTCH1 coding exons and sequence traces from SMO exon 4 and 5 of resistant tumour tissue. A. The top panel confirms the absence of a germline mutation in buccal swab. The primary tumour and resistant tumour, panel 2 and 4 respectively, both harbour the same splice site mutation (arrows) and skewed nucleotide (arrowhead) distribution (indicative of loss of heterozygosity). In the responding tissue, a PTCH1 mutation could no longer be identified. B. Top panels represent resistant tumour 1 and lower panels resistant tumour 2. Arrows indicate the mutations in either exon 4 (left panels) for resistant tumour 2 or exon 5 (right panels) for resistant tumour 1 . If the mutation is present in 1 tumour, it is not in the other and vice versa. Normal tissue, primary tumour, and responding tumour tissue display similar wild type sequence (not shown). 


\section{References}

1. Bath-Hextall FJ, Perkins W, Bong J, Williams HC. Interventions for basal cell carcinoma of the skin. Cochrane Database of Systematic Reviews (Online) 2007:CD003412.

2. Epstein EH. Basal cell carcinomas: attack of the hedgehog. Nat Rev Cancer 2008;8:743-54.

3. Erivedge SmPC, July 2013. Available at: https://www.medicines.org.uk/emc/medicine/28107/SPC/ Erivedge+150+mg+hard+capsules/. Accessed August 26, 2014.

4. Dijkgraaf GJ, Alicke B, Weinmann L, Januario T, West K, Modrusan Z, et al. Small molecule inhibition of GDC-0449 refractory smoothened mutants and downstream mechanisms of drug resistance. Cancer Res 2011;71:435-44.

5. Flaherty KT, Infante JR, Daud A, Gonzalez R, Kefford RF, Sosman J, et al. Combined BRAF and MEK inhibition in melanoma with BRAF V600 mutations. N Engl J Med 2012;367:1694-703. 




\section{Chapter 9}

\section{Epidermal cyst formation and hyperkeratosis in a patient treated with vismodegib for locally advanced basal cell carcinoma}

Reinders MG*, Brinkhuizen T*, Soetekouw PM, Kelleners-Smeets NW, Abdul Hamid MA, Mosterd K

Acta Dermato Venereologica 2015 Apr

*Both authors contributed equally to this paper and should be considered as first authors. 



\section{Introduction}

Vismodegib, a hedgehog (Hh) pathway inhibitor, was approved in 2012 by the US Food and Drug Administration (FDA) for the treatment of locally advanced (la) and metastatic ( $\mathrm{m}$ ) basal cell carcinoma (BCC). Interim results of the largest clinical study of vismodegib have shown complete (17.5\%) or partial (39.8\%) response, and stable (39.0\%) or progressive (2.8\%) disease in 251 cases of laBCC and mBCC. ${ }^{1}$ Formation of squamous cell carcinoma (SCC) within the tumour area, as well as occurrence of SCC at other body sites, has been reported in patients treated with vismodegib. $2-6$ To our knowledge this is the first report of formation of epidermal cysts and hyperkeratosis within the tumour area during treatment with vismodegib. 


\section{Case report}

A 52-year-old man was referred to our hospital with a recurrent BCC that was treated with cryotherapy 15 years previously, followed by multiple incomplete excisions. An area of scar tissue and minimal hyperkeratosis was visible on the nose, extending to his right cheek and upper lip (Figure 1A). Several biopsies were taken, and showed infiltrative BCC invading the deep dermis; there was subtle hyperkeratosis, but no evidence of SCC or BCC with squamous differentiation (Figure 2A). To avoid mutilating surgery, the patient was enrolled in a clinical trial with oral vismodegib $150 \mathrm{mg}$ daily. ${ }^{\top}$ This trial was approved by the ethics and scientific committee of the Maastricht University Medical Centre. After 7 weeks of treatment, hyperkeratosis increased and comedo-like lesions developed on the nose (Figure 1B). Sequential skin biopsies showed epidermal cysts, but no residual BCC was found. Because of the impressive hyperkeratosis, we feared for progression into SCC despite the absence of malignancy in repeated biopsies, taking the possibility of a sampling error into account. Therefore, we performed Mohs' micrographic surgery 5 months after initiation of vismodegib therapy, which was continued until the day before surgery. Five stages of Mohs' surgery with 19 frozen sections, including nose amputation, were necessary to achieve clear margins. Histological examination showed residual infiltrative BCC, accompanied by epidermal cyst formation and some hyperkeratosis, but no evidence of SCC (Figure 2B). Immunohistochemical analysis confirmed residual BCC cells by positive staining for Ber-Ep4, whereas epidermal cysts stained negative. 


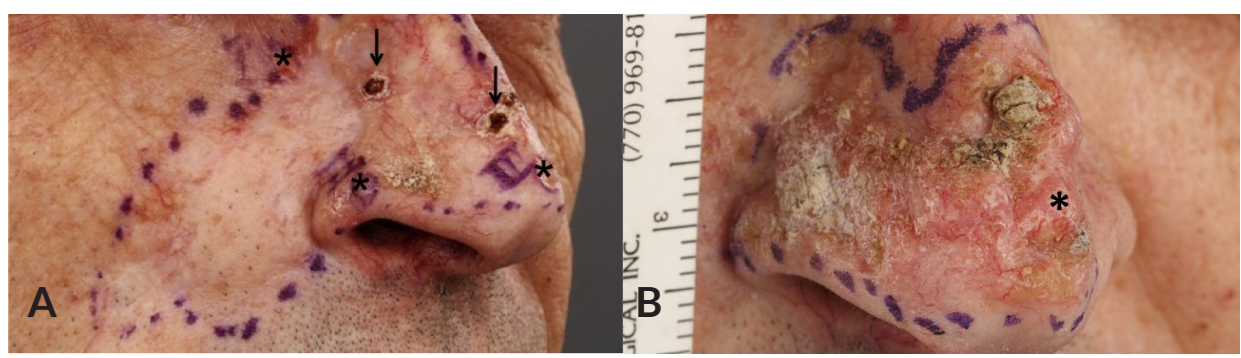

Figure 1A. Clinical picture before treatment with vismodegib. Biopsy sites $\left({ }^{*}\right)$ were positive for infiltrative basal cell carcinoma (BCC) Crusts from earlier biopsy sites ( $\downarrow)$, also positive for BCC. B. Clinical picture with extensive hyperkeratosis and comedo-like lesions after 7 weeks treatment with vismodegib. Biopsy site $\left(^{*}\right)$.

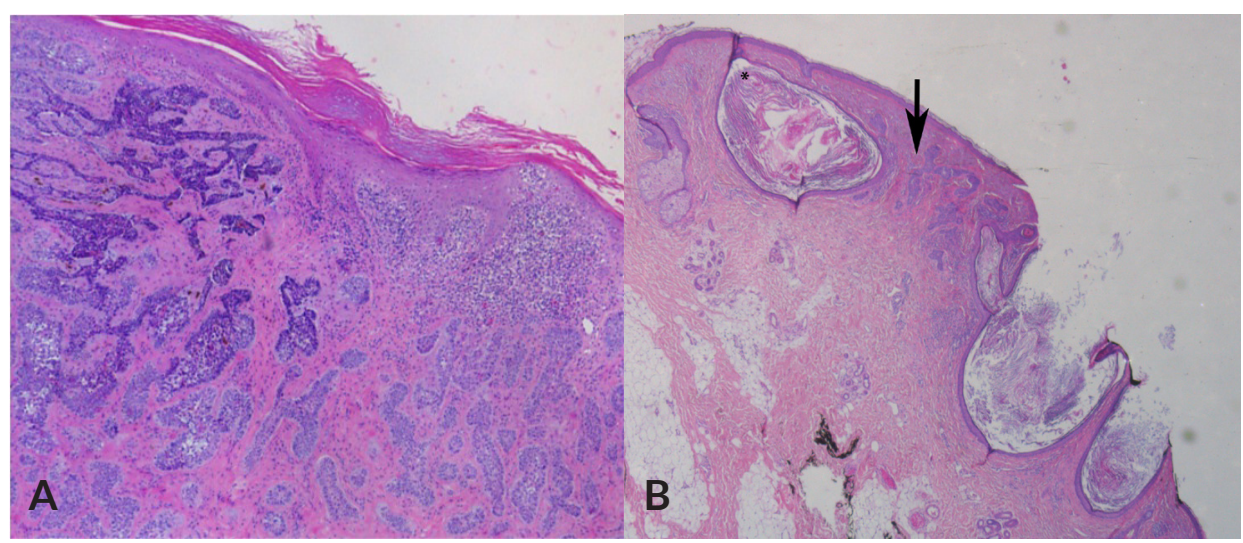

Figure 2. Histological examination. A. Skin biopsy before treatment with vismodegib, showing infiltrative basal cell carcinoma (BCC). B. Skin excision specimen with epidermal cyst $\left(^{*}\right)$ formation and infiltrative BCC $(\downarrow)$. Haematoxylin-eosin stain (20X). 


\section{Discussion}

Pseudocyst-like structures as a result of tumour regression during the use of vismodegib have been reported previously; however, they were characterized by a different histology with so-called pseudocystic areas consisting of extensive fibrosis and some residual BCC cells but without keratin formation. ${ }^{8}$ Formation of SCC within the initial BCC has been reported in several patients treated with vismodegib as well as development of SCC and keratoacanthoma on other body sites. ${ }^{2-6}$ It is therefore important to be aware of the possibility of occurrence of SCC during vismodegib treatment and to perform sequential biopsies from suspicious areas. Tumour heterogeneity may underlie the emergence of SCC within the tumour area. Squamous differentiation is common in BCC and a subset of malignant squamous cells could become predominant when the BCC is treated with vismodegib. However, this does not explain the occurrence of squamous neoplasms on other sites of the body or, as in our case, the development of benign squamous neoplasia. Furthermore, the epithelial cell marker BerEP4 negative immunohistochemical staining of the epidermal cysts in our patient speaks against the survival of cells from the original tumour, as BCC and basosquamous carcinoma stain Ber-EP4 positive. A possible explanation for the emergence of the benign squamous neoplasms could be an effect of vismodegib on keratinocyte differentiation. In essentially all BCC, loss of function mutations in the tumour suppressor gene patched-1 (PTCH1) prevent binding of Sonic Hh to the transmembrane protein PTCH1, resulting in activation of the $\mathrm{Hh}$ signalling pathway and eventually tumour formation. The Hh pathway seems to be important in keratinocyte differentiation and proliferation, as Indian hedgehog (Ihh), another member of the Hh ligand family, plays an important role here, and loss of Ihh promotes the progression of benign papillomas to SCC. ${ }^{9}$ Vismodegib treatment could mimic loss of Ihh, as both reduce Hh pathway activation. Therefore, an effect of vismodegib on keratinocyte differentiation seems plausible. Functional analysis might clarify the exact effect of vismodegib on keratinocyte differentiation and proliferation. 


\section{References}

1. Grob JJ KR, Dreno B, Jouary T, Mortier L, Basset-Seguin N, Ascierto PA, Hansson J, Mitchell L, Starnawski M, Hauschild A. Vismodegib, a Hedgehog pathway inhibitor (HPI), in advanced basal cell carcinoma (aBCC): STEVIE study interim analysis in 300 patients. Poster discussion meeting. American Society of Clinical Oncology, 2013.2013.

2. Iarrobino A, Messina JL, Kudchadkar R, Sondak VK. Emergence of a squamous cell carcinoma phenotype following treatment of metastatic basal cell carcinoma with vismodegib. Journal of the American Academy of Dermatology 2013;69:e33-4.

3. Saintes C, Saint-Jean M, Brocard A, et al. Development of squamous cell carcinoma into basal cell carcinoma under treatment with Vismodegib. Journal of the European Academy of Dermatology and Venereology: JEADV 2015;29:1006-9.

4. Zhu K, Zhang W, Wu A, Zhang X. A comparative study of two wayfinding aids for simulated driving tasks - single-scale and dual-scale GPS aids. Behaviour \& Information Technology 2014;33:361-71.

5. Orouji A, Goerdt S, Utikal J, Leverkus M. Multiple highly and moderately differentiated squamous cell carcinomas of the skin during vismodegib treatment of inoperable basal cell carcinoma. The British journal of dermatology 2014;171:431-3.

6. Aasi S, Silkiss R, Tang JY, et al. New onset of keratoacanthomas after vismodegib treatment for locally advanced basal cell carcinomas: a report of 2 cases. JAMA dermatology 2013;149:242-3.

7. STEVIE: A study of vismodegib in patients with locally advanced or metastatic basal cell carcinoma. 2011 May 30 ed. ClinicalTrials.gov. : Bethesda (MD): National Library of Medicine (US).

8. Maier T, Kulichova D, Ruzicka T, Berking C. Noninvasive monitoring of basal cell carcinomas treated with systemic hedgehog inhibitors: pseudocysts as a sign of tumor regression. Journal of the American Academy of Dermatology 2014;71:725-30.

9. Kakanj P, Reuter K, Sequaris G, et al. Indian hedgehog controls proliferation and differentiation in skin tumorigenesis and protects against malignant progression. Cell Rep 2013;4:340-51. 



\section{Chapter 10}

Summary, discussion, future perspectives and valorisation 



\section{Part one \\ Basal cell naevus syndrome}

Basal cell naevus syndrome (BNCS), also known as Gorlin syndrome, is an autosomal dominant disorder, characterized by multiple basal cell carcinomas (BCCs), odontogenic keratocysts, cerebral calcifications and palmoplantar pits., ${ }^{1,2}$ The syndrome is associated with germline mutations in the Drosophila homolog of patched-1 (PTCH1) gene that encodes the PTCH1 protein. PTCH1 is part of the hedgehog ( $\mathrm{Hh}$ ) signalling pathway, which plays an important role in the regulation of cell growth and differentiation. BCNS belongs to the group of hereditary tumour syndromes, in which mutations in one or more genes predispose to the development of cancer. The development of sometimes hundreds of BCCs is a major problem in this group of patients.

\section{Genetic basis of BCNS}

In 1996 the patched-1 (PTCH1) gene (MIM\#601309) was first reported as a candidate gene for BCNS. Two different heterozygous mutations in the PTCH1 gene were identified in two patients with BCNS. ${ }^{3}$ PTCH1 is the human homolog of the Drosophila patched-1 gene and is located on chromosome 9q22.3. With DNA sequencing analysis of the PTCH1 gene, mutation detection frequency ranges from $40 \%$ to $85 \%$ in individuals with typical findings of BCNS..$^{4-8}$ In chapter 2 we describe a new database containing all previously published and newly identified PTCH1 mutations. We established a database for PTCH1 using the Leiden Open Variation Database (LOVD) version 3.0. ${ }^{9}$ The purpose of this database is to assemble molecular variants of the PTCH1 gene in a standardised format. The database provides an open collection for both clinicians and researchers containing published and unpublished PTCH1 mutations. To accomplish this, we listed the results from all blood samples sent to the two Diagnostic DNA Laboratories in the Netherlands for PTCH1 mutation analysis between 1999 and 2015. In

chapter $\mathbf{3}$ we investigate whether there is a genotype-phenotype correlation in this population by collecting clinical symptoms from patients' medical records. In this research, we only looked at the patients who carried a PTCH1 mutation in the blood. In the investigated Dutch cohort, we did not find a genotype-phenotype correlation based either on the location or on the type of PTCH1 mutation. Our findings are consistent with the results of previous studies and are in line with the phenotype variability within families found in this study.,10-13 The presence of a germline mutation in SUFU increases the risk of developing medulloblastoma in childhood. ${ }^{6}$ The presence of genetic variants (polymorphisms (SNPS), modifiers) that increase the risks of developing sporadic BCC, like MC1R and TERT-CLPTM1L, is associated with an earlier age of onset for BCCs in BCNS. ${ }^{14}$ The mutation detection percentage in our population is low (21\%). Probably, relatively many patients with only minimal clinical symptoms of BCNS were tested. Another explanation can be that for many patients with clinical suspicion of BCNS, standard genetic tests are not yet suitable to detect the underlying genetic cause of the symptoms. 


\section{Postzygotic mosaicism in BCNS}

In a substantial number of BCNS patients no PTCH1 mutation is found in DNA extracted from blood. It is known that genomic rearrangments in PTCH1 or deep intronic variants causing cryptic splicing cannot be detected with generally used genetic diagnostic tests. ${ }^{15}$ Also, mutations could be located in other genes involved in the Hh pathway (or yet unknown pathways), for example SUFU or PTCH2. ${ }^{6,16-18}$ Another explanation is the presence of genetic mosaicism. Low-grade mosaicism can be difficult or even impossible to detect in DNA extracted from blood. With standard techniques, e.g. Sanger sequencing, mutation loads under 5\% are not detectable. Next generation sequencing (NGS) of target genes (i.e. PTCH1) in blood is more sensitive and has sufficient sequence read depth to not only reliably detect, but also quantify the degree of mosaicism ${ }^{19}$. Sometimes though, a mutation is only present in the skin and cannot be found in blood. When the presence of a mutation causes visible skin lesions, as in mosaic ichthyosis, the segmentally appearing skin disorder is an evident clue for the existence of segmental mosaicism caused by dominant mutations. ${ }^{20}$ Mosaic skin diseases may present different patterns as described in chapter 1. Lesions can for example follow the lines of Blaschko, in broad or narrow bands, or appear in a checkerboard pattern. ${ }^{21}$ In BCNS, but also in other hereditary tumour syndromes, skin with only one affected allele has a normal appearance. Only a second hit of the other allele, through loss-of-heterozygosity $(\mathrm{LOH})$ or somatic gene mutation, initiates the development of a BCC. As the presence of a BCC is a marker for affected skin, genetic mosaicism in the patient can be demonstrated when different BCCs share the same PTCH1 mutation. In chapter $\mathbf{4}$ and $\mathbf{5}$ we described three patients with BCNS caused by PTCH1 mosaicism. Only in one patient there is a clear segmental distribution of skin lesions as they are limited to only one side of the body. This emphasizes the difficulty of recognizing a mosaic presentation of BCNS. To demonstrate a shared mutation in the different BCCs of these patients we used NGS in combination with a gene panel, consisting of a selection of genes participating in the Hh pathway including PTCH1, PTCH2, SUFU and SMO. Mosaic mutations in the latter has been described in Happle-Tinschert syndrome, that should be distinguished from mosaic BCNS22,23

Mosaic manifestations of other hereditary tumour syndromes have been described as well, for example neurofibromatosis type $1 .{ }^{24}$ In BCNS PTCH1 postzygotic mosaicism could actually be more common than previously assumed. It is plausible that patients do not always fulfil the diagnostic criteria of BCNS and may even present only with multiple BCCs at a young age. Of note, low-grade mosaicism can affect the gonadal cells as well. If this is the case, patients have a chance, although probably very small, to give birth to a child with a germline mutation of the disease. Unfortunately, the degree of involvement of different organ systems is difficult to predict. Therefore, surveillance programs and treatment of BCCs should have the same approach as in patients with a germline mutation. So, in patients suspected of having BCNS and a negative mutation analysis on blood, even with NGS techniques, it is worthwhile to search for a shared mutation in their BCCs. In case of mosaic disease, genetic counselling can be adjusted. 


\section{Care pathways and patient customized health care}

Currently, our department is developing an integrated care pathway for patients with BCNS. This project is a collaboration between different specialties: paediatrics, clinical genetics, maxillary surgery, (paediatric) neurology, ophthalmology, cardiology, gynaecology, psychology and medical oncology, with the dermatologist as the initiator of the project. The purpose of this plan is to standardize the health care for this group of patients based on best available evidence. The dermatologist has a central position in this care pathway, as the management of the multiple BCCs is a difficult and ongoing problem. Information about sun protective measures are very important in patients with BCNS, as individuals with a low tumour burden have significantly fewer UV signature somatic mutations. ${ }^{25}$ Our dermatology department offers specialized consultations for patients with BCNS. Treatment of multiple BCCs can be very complex and has a high psychological impact on patients. Different treatment modalities are available, and choices are preferably made combining evidence-based medicine with shared decision-making. Maintenance therapy with Hh pathway inhibitors, such as vismodegib, can be considered in selected patients as I will discuss in more detail in part two of this chapter.

\section{Future perspectives}

Insight into the genetic cause of BCNS is not only helpful to understand the pathogenesis of this syndrome. For the individual patient, it is just as important, because it allows us to diagnose the disease at an early age and to offer patients correct screening programs and adequate genetic counselling.

Whole Exome Sequencing (WES) is increasingly used, especially in syndromes with no clearly defined candidate gene or in very heterogeneous diseases, because it enables the sequencing of all genes in one go. The method is however still costly and moreover it has a limited sequencing depth. ${ }^{19}$ In case of a high clinical suspicion of BCNS it is more efficient to look specifically at participants of the Hh pathway. We designed an NGS-based gene panel that includes PTCH1, PTCH2, SMO and SUFU. Its implementation in daily practice will provide a more effective, faster and less expensive diagnostic screening method for BCNS patients. Because of the higher sequencing depth, mosaic disease is more likely to be discovered. In patients with a high suspicion of BCNS in whom no PTCH1 mutation can be detected in blood with regular Sanger sequencing, it is worthwile to implement the gene panel, in order to analyze other genes involved in the Hh pathway, but also to reach a sequencing depth sufficient to detect low-grade mosaicism. To gain more information about the prevalence of mutations in other genes and the presence of mosaic disease in BCNS, it is of interest to look at the patients in our initial cohort that had no mutation in blood. 


\section{Part two \\ Treatment of locally advanced and metastasised basal cell carcinoma with vismodegib}

The development of Hh pathway inhibitors provided a new treatment option for patients with metastasized or locally advanced BCC ineligible for surgery or radiotherapy. In chapter $\mathbf{6}$ we described the first Dutch patient who was treated with vismodegib for a locally advanced BCC with locoregional metastasis of her BCC. An interesting detail is the presence of BCNS in this patient, already giving a preview of the effects of vismodegib on the multiple small BCCs in BCNS. Since the registration of the Hh pathway inhibitor vismodegib in the Netherlands in 2014, it is possible to treat patients outside the clinical trial setting. However, it is important to realise that only very few patients with BCC are candidates for this systemic therapy. In 2015 only 25 patients were treated for this indication in the Netherlands. Although treatment with Hh pathway inhibitors is initially effective, development of tumour resistance is common and adverse events frequently lead to discontinuation of therapy. Some patients with BCNS benefit from treatment with oral Hh pathway inhibitors, but especially in this group side effects are an important reason to discontinue therapy. An overview of treatment of BCC with $\mathrm{Hh}$ pathway inhibitors is given in chapter $\mathbf{7}$ and some aspects of this treatment are discussed in more detail below. We published the topics mentioned above in a national journal, as we believe it is important to share experiences on new treatment options.

\section{Efficacy and side effects}

Vismodegib is a small molecule inhibitor targeting the Hh pathway. Binding of vismodegib to SMO leads to inactivation of this pathway. ${ }^{26}$ Because most BCC s carry mutations in PTCH1 (the inhibitor of SMO) resulting in upregulation of the Hh pathway, ${ }^{25}$ vismodegib is initially effective in the vast majority of patients. The STEVIE trial assessed the safety and efficacy of vismodegib in patients with advanced BCC. ${ }^{27,28}$ In this trial 1215 patients (1119 laBCC, 96 mBCC) were treated with vismodegib with a mean follow-up of 18 months. The best measured response rate in patients with laBCC was a complete response in 33\% and a partial response in 35\%, stable disease in $25 \%$ and progressive disease in $2 \%$ of patients. The median duration of response was 23 months. In metastatic BCC the efficacy was lower. In only 5\% of patients the best measured response was a complete response, in 32\% a partial response, in $46 \%$ stable disease and progressive disease in 11\%. The median duration of response was 12 months. At the clinical cut-off of the study, only $12 \%$ of patients were still receiving treatment with vismodegib. Main reasons to discontinue treatment were side effects and progressive disease. The presence of BCNS did not affect the efficacy of vismodegib. ${ }^{28}$ 
In general, 30 to $40 \%$ of patients discontinued therapy because of side effects. ${ }^{28}$ In patients treated because of BCNS-related multiple small BCCs even more than $50 \%$ could not continue therapy because of drug toxicity. ${ }^{29,30}$ Most frequently reported side effects, in about half of patients, are muscle cramps, dysgeusia and alopecia. Weight loss is reported in $33 \%$ of patients, possibly related with dysgeusia, but probably also due to changes in fat metabolism caused by the medication. ${ }^{28}$ Diarrhoea, nausea and fatigue are other common side effects. The development of cutaneous squamous cell carcinoma (SCC) during vismodegib therapy has been reported as well. ${ }^{31}$ The actual clinical impact of this observation is not clear, as later studies did not find a higher incidence of SCC during treatment. ${ }^{32}$

Proper patient support and consultation of a dietician during treatment are essential to prevent weight loss. Intermittent treatment is already implemented in clinical practice to reduce toxicity. Unfortunately, studies on intermittent dosing regimens only show reduction in toxicity to a certain level. ${ }^{33}$

\section{Drug resistance}

A major problem in the treatment of $\mathrm{BCC}$ with vismodegib is the development of drug resistance. The majority of tumours initially show a complete or partial response to treatment with vismodegib. Only few BCCs do not respond at all, so called non-responders. The mean duration of response to therapy is 24 months. ${ }^{27}$ It is thought that about $15-20 \%$ of patients develop resistance, the exact percentage is unknown. ${ }^{27,43}$ The number of resistant cases is probably underestimated because of the short follow-up and the slow growth of BCC. In chapter $\mathbf{8}$ we describe two patients with locally advanced BCC, who are resistant to vismodegib. These cases illustrate how important it is to monitor the tumour area very carefully and perform sequential biopsies when needed.

Genetically, BCC is one of the most heterogenic forms of cancer. ${ }^{25}$ However, for their growth BCCs are almost completely dependent on the Hh pathway. Genetic alterations that maintain Hh signalling in the presence of vismodegib are the primary mechanism of resistance. In chapter 9 we describe a patient with acquired resistance to vismodegib due to SMO mutations. At the same time, it was found that drug resistance to vismodegib in the treatment of $\mathrm{BCC}$ is predominantly caused by SMO mutations that either directly impair drug binding or activate SMO to varying levels. ${ }^{35,36}$ The question is whether responsible mutations are acquired during treatment, or that they already existed before treatment. In the latter case, the minor clones may have benefited from a positive selection effect when other cells were killed by vismodegib. In the future, combination treatments should be developed to overcome or slow down the development of resistance. Drugs should inhibit SMO through different mechanisms or target the Hh pathway at points downstream of SMO. Several drug candidates are suggested in literature, for example itraconazol, bis-amides, arsenic oxide, protein-kinase inhibitors and mTOR inhibitors. ${ }^{37-40}$ There 
are indications that imiquimod inhibits the Hh pathway as well. ${ }^{41}$ Furthermore, GLI-antagonists are very promising as they target the GLI transcription factors that are most downstream in the Hh pathway. ${ }^{42}$ Further research is needed to explore possible clinical applications of these drugs, especially in respect to pharmacokinetics and toxicity.

\section{Hh inhibitors in basal cell naevus syndrome}

Vismodegib has proven to be effective in the treatment of BCNS related BCCs. Existing BCCS disappear and development of new tumours is delayed. 29,30 Unfortunately, discontinuation of treatment is common, mainly because of the side effects. Development of tumour resistance also occurs in patients with BCNS when it comes to laBCC or mBCC, but maybe to a more limited extent then in patients with sporadic BCC. Resistance is caused by the same underlying mechanism as in sporadic BCCs, as acquired SMO mutations are found in resistant tumour tissue. ${ }^{30}$ However, the BCNS-related small BCCs seem to develop resistance less frequently. ${ }^{30}$ This is probably because small BCCs are less heterogenic then the large laBCCs. ${ }^{25}$ There is also evidence that syndromic BCCs have a lower mutational load and better genomic stability compared to sporadic BCCs, irrespective of the size of the tumour. ${ }^{43}$ Studies on intermittent treatment dosing regimens in patients with multiple BCCs show that interruption of treatment does not compromise activity of vismodegib, but only leads to some reduction in toxicity. ${ }^{33}$ Optimal treatment regimens should be personalized and aim to strike a balance between sufficient activity and acceptable side effects as these patients need long-term treatment. At this moment vismodegib is not registered for treatment of multiple BCNS-related small BCCs. However, surgical treatment of the high number of BCCs may have unacceptable high morbidity in some patients. Radiotherapy is contraindicated in BCNS because of the induction of new tumours. Therefore, in selected patients with BCNS there is an indication for maintenance therapy with Hh pathway inhibitors.

\section{Neoadjuvant therapy}

One should be very cautious in using vismodegib as a neoadjuvant therapy in clinical practice. Treatment with vismodegib can cause discontinuous growth of the tumour, leading to an unreliable histological margin assessment. ${ }^{44}$ There is strong evidence that tumour cells remain present and become clinically manifest after treatment discontinuation. ${ }^{35,45}$ This means that to achieve a complete surgical resection the whole initially affected area should be removed anyway, so there is no benefit in reducing the tumour size before surgery. An interesting treatment option for non-syndromic locally advanced BCC is the combination of radiotherapy and vismodegib. This seems to be an effective and tolerable combination therapy, with a possible synergistic effect, but the results of a phase 2 trial are not yet available..$^{46-48}$ 


\section{Treatment settings and personalized medicine}

A multidisciplinary oncological team in which a dermatologist, head and neck surgeon, oncological surgeon, radiotherapist, plastic surgeon and medical oncologist are represented, is the preferred setting for treatment of locally advanced BCC with Hh inhibitors. ${ }^{49}$ Only then all treatment options can be considered and experiences shared. Not only tumour characteristics are important in deciding which treatment is best for the patient, also patient characteristics are of great significance. The majority of skin cancer occurs in the elderly. In the ageing population, frailty is an important issue. The term frailty refers to a state of vulnerability to poor resolution of homoeostasis after a stressor event and is a consequence of cumulative decline in many physiological systems during a lifetime. ${ }^{50}$ In frail elderly, a minor stressor can trigger disproportionate changes in health status. In frail elderly with advanced BCC, surgery may be technically achievable, but associated with a high morbidity when complicated by for example delirium or hospital acquired pneumonia. Treatment with surgery or radiotherapy may lead to an impaired quality of life, for example when the BCC involves the orbita and treatment requires an enucleation or exenteration of the eye or leads to vision loss by radiation-induced toxicity. In those patients, palliative treatment with vismodegib may be an option, but it is important to realise that side effects, like muscle cramps and dysgeusia, can also significantly influence quality of life. Involvement of a geriatrist in making treatment decisions can be helpful in these cases. ${ }^{51}$

\section{Future perspectives on Hh pathway inhibitors for BCC}

In the past decades, there has been a steep rise in the incidence of BCC. As BCC in general is a very slow growing tumour, it will take many years for it to become inoperable. As a logical consequence, the increase of neglected locally advanced tumours will lag many years behind the rise in incidence of $\mathrm{BCC}$ in general. As a direct result, in the nearby future an increasing number of patients with locally advanced or metastatic BCC that is ineligible for surgery or radiotherapy is to be expected. This emphasizes the need to optimize systemic treatment options for this group of patients.

Rapid advancement in our understanding of Hh signalling in BCC has provided a new systemic treatment option for this common form of skin cancer: Hh pathway inhibitors. We already have insight into the mechanism of the development of resistance to $\mathrm{Hh}$ inhibitors in the treatment of BCC. In a next stage, treatment strategies to overcome the development of resistance need to be investigated. Combination therapy probably provides the best perspective. Different drug candidates are proposed in literature. However, development of combination therapy still has a long way to go before it can be used in clinical practice. 
For the small BCNS related BCCs topical Hh inhibitors are a promising treatment option. The topical SMO inhibitor patidegib has been developed for this indication. ${ }^{52}$ Results from a phase II trial in which patients with BCNS are treated with patidegib have not yet been published. A multicentre phase 3 trial will start this year, with the MUMC as participating centre in the Netherlands.

The past years have seen many significant achievements in the field of cancer genetics, driven by rapidly evolving technologies and decreasing costs of next-generation sequencing (NGS). NGS is already used in clinical practice in several forms of cancer to predict responsiveness to therapy. The term 'precision oncology' was introduced, referring to the molecular profiling of tumours to identify targetable alterations and to predict response to therapies. Precision oncology simply means to give the right drugs to the right patients. ${ }^{19}$ In BCC, an NGS targeted panel consisting of genes participating in the Hh pathway allows us to analyse tumour tissue relatively cheaply and fast. With this technique, it is also possible to analyse paraffin embedded tissue. In the future, NGS will probably contribute to making treatment decisions for locally advanced or metastatic BCC. 


\section{References}

1. John AM, Schwartz RA. Basal cell naevus syndrome: an update on genetics and treatment. Br J Dermatol 2016;174(1):68-76.

2. Gorlin RJ, Goltz RW. Multiple nevoid basal-cell epithelioma, jaw cysts and bifid rib. A syndrome. N Engl J Med 1960;262:908-12.

3. Johnson RL, Rothman AL, Xie J, et al. Human homolog of patched, a candidate gene for the basal cell nevus syndrome. Science. 1996 Jun 14;272(5268):1668-71.

4. Wicking C, Shanley S, Smyth I, et al. Most germ-line mutations in the nevoid basal cell carcinoma syndrome lead to a premature termination of the PATCHED protein, and no genotype-phenotype correlations are evident. Am J Hum Genet 1997;60(1):21-6.

5. Klein RD, Dykas DJ, Bale AE. Clinical testing for the nevoid basal cell carcinoma syndrome in a DNA diagnostic laboratory. Genet Med 2005;7(9):611-9.

6. Smith MJ, Beetz C, Williams SG, et al. Germline mutations in SUFU cause Gorlin syndrome-associated childhood medulloblastoma and redefine the risk associated with PTCH1 mutations. J Clin Oncol 2014;32(36):4155-61.

7. Marsh A, Wicking C, Wainwright B, Chenevix-Trench G. DHPLC analysis of patients with Nevoid Basal Cell Carcinoma Syndrome reveals novel PTCH missense mutations in the sterol-sensing domain. Hum Mutat 2005;26(3):283.

8. Soufir N, Gerard B, Portela M, et al. PTCH mutations and deletions in patients with typical nevoid basal cell carcinoma syndrome and in patients with a suspected genetic predisposition to basal cell carcinoma: a French study. Br J Cancer 2006;95(4):548-53.

9. Geel HG and M van. Variants of patched 1 (PTCH1) :Leiden Open Variation Database (LOVD) 3.O. Available from: http://databases.lovd.nl/shared/transcripts/00017082

10. Jones EA, Sajid MI, Shenton A, Evans DG. Basal cell carcinomas in gorlin syndrome: a review of 202 patients. J Ski Cancer 2011;2011:217378.

11. Tanioka M, Takahashi K, Kawabata T, et al. Germline mutations of the PTCH gene in Japanese patients with nevoid basal cell carcinoma syndrome. Arch Dermatol Res 2005;296(7):303-8.

12. Torrelo A, Vicente A, Navarro L, et al. Early-onset acral basal cell carcinomas in Gorlin syndrome. Br J Dermatol 2014;171(5):1227-9.

13. Evans DG, Oudit D, Smith MJ, et al. First evidence of genotype-phenotype correlations in Gorlin syndrome. J Med Genet 2017;54(8):530-6.

14. Yasar B, Byers HJ, Smith MJ, et al. Common variants modify the age of onset for basal cell carcinomas in Gorlin syndrome. Eur J Hum Genet 2015;23(5):708-10.

15. Bholah Z, Smith MJ, Byers HJ, Miles EK, Evans DG, Newman WG. Intronic splicing mutations in PTCH1 cause Gorlin syndrome. Fam Cancer 2014;13(3):477-80.

16. Pastorino L, Ghiorzo P, Nasti S, et al. Identification of a SUFU germline mutation in a family with Gorlin syndrome. Am J Med Genet A 2009;149A(7):1539-43.

17. Fan Z, Li J, Du J, et al. A missense mutation in PTCH2 underlies dominantly inherited NBCCS in a Chinese family. J Med Genet 2008;45(5):303-8.

18. Fujii $\mathrm{K}$, Ohashi H, Suzuki M, et al. Frameshift mutation in the PTCH2 gene can cause nevoid basal cell carcinoma syndrome. Fam Cancer 2013;12(4):611-4.

19. Horak P, Fröhling S, Glimm H. Integrating next-generation sequencing into clinical oncology: strategies, promises and pitfalls. ESMO Open 2016;1(5):e000094. 
20. Toberer F, Happle R, Schneiderbauer R, et al. At first sight or second glance: clinical presentation of mosaic manifestations of autosomal dominant skin disorders - a case series. J Eur Acad Dermatol Venereol 2017 Nov;31(11):1912-1915

21. Happle R. Mosaicism in human skin. Understanding the patterns and mechanisms. Arch Dermatol 1993;129(11):1460-70.

22. Khamaysi Z, Sprecher E, Bergman R. Happle-Tinschert syndrome can be caused by a mosaic SMO mutation and is suggested to be a variant of Curry-Jones syndrome: reply from the authors. Br. J. Dermatol. 2016;175(5):1109.

23. Zenker M, Tinschert S, Wieland I, Schanze D, Happle R. A postzygotic SMO mutation caused the original case of Happle-Tinschert syndrome. Acta Derm Venereol 2018;98:534-5.

24. García-Romero MT, Parkin P, Lara-Corrales I. Mosaic Neurofibromatosis Type 1: A Systematic Review. Pediatr Dermatol. 2016 Jan-Feb;33(1):9-17.

25. Bonilla X, Parmentier L, King B, et al. Genomic analysis identifies new drivers and progression pathways in skin basal cell carcinoma. Nat Genet 2016;48(4):398-406.

26. Epstein EH. Basal cell carcinomas: attack of the hedgehog. Nat Rev Cancer 2008;8(10):743-54.

27. Basset-Seguin N, Hauschild A, Grob JJ, et al. Vismodegib in patients with advanced basal cell carcinoma (STEVIE): a pre-planned interim analysis of an international, open-label trial. Lancet Oncol 2015;16(6):729-36.

28. Basset-Seguin N, Hauschild A, Kunstfeld R, et al. Vismodegib in patients with advanced basal cell carcinoma: Primary analysis of STEVIE, an international, open-label trial. Eur J Cancer 2017;86:33448.

29. Tang JY, Mackay-Wiggan JM, Aszterbaum M, et al. Inhibiting the hedgehog pathway in patients with the basal-cell nevus syndrome. N Engl J Med 2012;366(23):2180-8.

30. Tang JY, Ally MS, Chanana AM, et al. Inhibition of the hedgehog pathway in patients with basal-cell nevus syndrome: final results from the multicentre, randomised, double-blind, placebo-controlled, phase 2 trial. Lancet Oncol 2016;17(12):1720-31.

31. Mohan S V, Chang J, Li S, Henry AS, Wood DJ, Chang AL. Increased Risk of Cutaneous Squamous Cell Carcinoma After Vismodegib Therapy for Basal Cell Carcinoma. JAMA Dermatol [Internet] 2016;152(5):527-32.

32. Bhutani T, Abrouk M, Sima CS, et al. Risk of cutaneous squamous cell carcinoma after treatment of basal cell carcinoma with vismodegib. J Am Acad Dermatol 2017;77(4):713-8.

33. Dreno B, Kunstfeld R, Hauschild A, et al. Two intermittent vismodegib dosing regimens in patients with multiple basal-cell carcinomas (MIKIE): a randomised, regimen-controlled, double-blind, phase 2 trial. Lancet Oncol 2017;18(3):404-12.

34. Chang ALS, Oro AE. Initial assessment of tumor regrowth after vismodegib in advanced basal cell carcinoma. Arch Dermatol 2012;148(11):1324-5.

35. Atwood SX, Sarin KY, Whitson RJ, et al. Smoothened variants explain the majority of drug resistance in basal cell carcinoma. Cancer Cell [Internet] 2015;27(3):342-53.

36. Sharpe HJ, Pau G, Dijkgraaf GJ, et al. Genomic analysis of smoothened inhibitor resistance in basal cell carcinoma. Cancer Cell 2015;27(3):327-41.

37. Dreier J, Dummer R, Felderer L, Nageli M, Gobbi S, Kunstfeld R. Emerging drugs and combination strategies for basal cell carcinoma. Expert Opin Emerg Drugs 2014;19(3):353-65.

38. Brechbiel J, Miller-Moslin K, Adjei AA. Crosstalk between hedgehog and other signaling pathways as a basis for combination therapies in cancer. Cancer Treat. Rev. 2014;40(6):750-9.

39. Dong X, Wang C, Chen Z, Zhao W. Overcoming the resistance mechanisms of Smoothened inhibitors. Drug Discov. Today. 2018;23(3):704-10. 
40. Kim AL, Back JH, Chaudhary SC, Zhu Y, Athar M, Bickers DR. SOX9 Transcriptionally Regulates mTORInduced Proliferation of Basal Cell Carcinomas. J. Invest. Dermatol. 2018;

41. Gruber W, Frischauf A-M, Aberger F. An old friend with new skills: Imiquimod as novel inhibitor of Hedgehog signaling in basal cell carcinoma. Oncoscience 2014;1:567.

42. A. G, S. I. Targeting the hedgehog signaling pathway in cancer: Beyond smoothened. Oncotarget. 2015;6(16):13899-913.

43. Chiang A, Jaju PD, Batra P, et al. Genomic Stability in Syndromic Basal Cell Carcinoma. J Invest Dermatol 2018;138(5):1044-51.

44. Aldabagh B, Yu J, Perkocha LA, Arron S. Histologic changes in basal cell carcinoma after treatment with vismodegib. Dermatol Surg 2013;39(11):1703-5.

45. Sánchez-Danés A, Larsimont JC, Liagre M, Muñoz-Couselo E, Lapouge G, Brisebarre A, Dubois C, Suppa M, Sukumaran V. Del Marmol V, Tabernero J, Blanpain C. A slow-cycling LGR5 tumour population mediates basal cell carcinoma relapse after therapy. Nature. 2018 Oct;562(7727):434438.

46. Pollom EL, Bui TT, Chang AL, Colevas AD, Hara WY. Concurrent Vismodegib and Radiotherapy for Recurrent, Advanced Basal Cell Carcinoma. JAMA Dermatol 2015;151(9):998-1001.

47. Hehlgans S, Booms P, Güllülü Ö et al. Radiation Sensitization of Basal Cell and Head and Neck Squamous Cell Carcinoma by the Hedgehog Pathway Inhibitor Vismodegib. Int J Mol Sci. 2018 Aug 23;19(9).

48. Phase II study of radiation therapy and vismodegib for advanced head/neck basal cell carcinoma. Clinicaltrials.gov NCT0183562.

49. Nederlandse Vereniging voor Dermatologie en Venereologie. Dutch Guideline Basal cell carcinoma. 2015;

50. Clegg A, Young J, Iliffe S, Rikkert MO, Rockwood K. Frailty in elderly people. In: The Lancet. 2013. p. 752-62.

51. Lubeek SFK, Borgonjen RJ, van Vugt LJ, Olde Rikkert MG, van de Kerkhof PCM, Gerritsen MJP. Improving the applicability of guidelines on nonmelanoma skin cancer in frail older adults: a multidisciplinary expert consensus and systematic review of current guidelines. Br J Dermatol 2016;175(5):1003-10.

52. www.pellepharm.com [Internet]. 



\section{Chapter 11}

Samenvatting 



\section{Samenvatting}

De hedgehog ( $\mathrm{Hh}$ )-signaaltransductieroute speelt een belangrijke rol in de pathogenese van het basaalcelcarcinoom. In het overgrote deel van de basaalcelcarcinomen worden mutaties gevonden in het PTCH1 gen. Dit tumorsuppressorgen codeert voor het PTCH1 eiwit, dat onderdeel uitmaakt van de Hh-signaaltransductieroute. Kiembaanmutaties in PTCH1 liggen bovendien ten grondslag aan het basaalcelnaevussyndroom (BCNS). Dit syndroom wordt gekenmerkt door onder andere cerebrale calcificaties, palmoplantaire pits en multipele basaalcelcarcinomen op jonge leeftijd. Dit proefschrift gaat over de rol van de Hh-signaaltransductieroute in de diagnostiek van BCNS en over de Hh-route als aangrijpingspunt voor 'targeted' ofwel doelgerichte therapie met Hh-signaaltransductieremmers.

Hoofdstuk 1 geeft een algemene inleiding op het proefschrift. De functie van de Hh-signaaltransductieroute en het tumorsuppressorgen PTCH1 en hun rol in de pathogenese van het basaalcelcarcinoom en BCNS worden uitgelegd. Daarnaast bevat het hoofdstuk achtergrondinformatie over genetisch mozaïcisme bij huidziekten en worden de doelstellingen van het proefschrift besproken.

In hoofdstuk 2 beschrijven we de totstandkoming van een database voor het PTCH1 gen, waarbij we gebruik maken van de Leiden Open Variation Database (LOVD). Aan deze database hebben we 331 reeds eerder gepubliceerde PTCH1 mutaties en 117 nieuwe PTCH1 mutaties toegevoegd. Deze mutaties werden gevonden bij 141 patiënten met een positieve PTCH1 mutatieanalyse, uitgevoerd in het VU Medisch Centrum of het Maastricht Universitair Medisch Centrum. De database is vrij toegankelijk voor clinici en onderzoekers en kan online geraadpleegd worden op http:/www.LOVD.nl/PTCH1.

Voor hoofdstuk 3 verzamelden we de klinische kenmerken van 83 Nederlandse patiënten met een PTCH1 mutatie in het bloed, om een eventuele genotype-fenotype correlatie te ontdekken bij patiënten met BCNS. We maakten verschillende heatmaps om deze correlatie te visualiseren. In de eerste heat-map werd de locatie van de mutatie in het gen uitgezet tegen de klinische kenmerken. In de tweede heatmap werd het type mutatie uitgezet tegen de klinische kenmerken. We vonden een grote variabiliteit van zowel genotype als fenotype, zonder aanwijzingen voor een genotype-fenotype correlatie

In hoofdstuk 4 beschrijven we een patiënte met symptomen van BCNS, veroorzaakt door een postzygotische mutatie in het PTCH1 gen. De graad van mozaïcisme werd bepaald middels Restriction Length Polymorphism Analysis en Droplet Digital Polymerase Chain Reaction. Het percentage cellen met een mutatie was bij benadering 16\% in de verschillende weefsels van deze patiënte. Onze bevindingen tonen aan dat een laaggradig mozaïcisme, een klinisch beeld 
kan geven dat voldoet aan de diagnostische criteria voor BCNS. Dit onderstreept het belang van genetisch onderzoek bij patiënten met een verdenking op BCNS, omdat de uitslag implicaties heeft voor de manier waarop de genetische counseling plaatsvindt. Standaard technieken zijn niet altijd geschikt om een laaggradig mozaïcisme op te pikken. Kwantitatieve genetische testen hebben de voorkeur, wanneer er een verdenking is op een genetisch mozaïcisme.

Hoofdstuk 5 borduurt voort op de inhoud van het vorige hoofdstuk. We beschrijven twee patiënten, bij wie we het vermoeden hadden dat er sprake was van BCNS, maar we geen PTCH1 mutatie konden aantonen in het bloed. Bij beide patiënten verrichtten we een genetische analyse van hun basaalcelcarcinomen, waarmee er in de verschillende tumoren een identieke PTCH1 mutatie kon worden aangetoond. Deze bevindingen tonen aan dat de symptomen van deze patiënten te verklaren zijn door een postzygotische PTCH1 mutatie. Wanneer er bij patiënten met klinische kenmerken van BCNS sprake is van een negatieve PTCH1 mutatieanalyse in het bloed, is het de moeite waard om een genetische analyse uit te voeren op verschillende basaalcelcarcinomen, aangezien hiermee genetisch mozaïcisme kan worden opgespoord.

Hoofdstuk 6 beschrijft de eerste Nederlandse patiënt die behandeld werd met de Hh-signaaltransductieremmervismodegib voor de indicatie gemetastaseerd basaalcelcarcinoom. Het basaalcelcarcinoom metastaseert slechts zelden, maar kent een slechte prognose. Er zijn geen prospectieve studies naar de behandeling van gemetastaseerd basaalcelcarcinoom met conventionele chemotherapie. Ten tijde van de casus waren Hh-remmers nog niet geregistreerd in Nederland voor de indicatie basaalcelcarcinoom. Patiënte kon in studieverband behandeld worden met de Hh-remmer vismodegib. Naast een aanhoudende complete remissie van de gemetastaseerde ziekte, verdwenen ook de multipele kleinere basaalcelcarcinomen, die zij had in het kader van BCNS.

Aan de hand van drie patiënten geven we in hoofdstuk 7 een overzicht van de behandeling van gemetastaseerd en lokaal uitgebreid basaalcelcarcinoom met de Hh-signaaltransductieremmer vismodegib. Ook bij bepaalde patiënten met BCNS heeft onderhoudstherapie met Hh-remmers een plaats. De effectiviteit van de behandeling voor de verschillende indicaties wordt besproken, evenals de bijwerkingen die kunnen optreden, zoals spierspasmen, haar-, en smaakverlies. De ontwikkeling van resistentie voor het medicijn is daarnaast een regelmatig voorkomend probleem. We geven aan dat de behandeling van het basaalcelcarcinoom met Hh-remmers bij voorkeur plaatsvindt in een multidisciplinair (hoofd-hals) team.

In hoofdstuk $\mathbf{8}$ en $\mathbf{9}$ presenteren we twee patiëntencasuïstieken, waarbij er sprake is van resistentie voor vismodegib bij de behandeling van basaalcelcarcinoom. De eerste casus betreft een patiënte met een lokaal uitgebreid basaalcelcarcinoom op de linker schouder, waarbij er initieel een complete respons optrad, maar tijdens behandeling een recidief ontstond. 
Genetische analyse van het recidief tumorweefsel, liet mutaties zien in het smoothened gen, die vóór de behandeling niet aanwezig waren in de tumor. Deze mutaties zijn verantwoordelijk voor de ontwikkeling van resistentie voor vismodegib. De tweede casus betreft een patiënt, met een lokaal uitgebreid basaalcelcarcinoom in het gelaat, waarbij de beoordeling van het behandelresultaat werd bemoeilijkt door het ontstaan van benigne huidafwijkingen in het tumorgebied tijdens behandeling met vismodegib. Beide patiënten werden uiteindelijk chirurgisch behandeld voor het basaalcelcarcinoom.

Hoofdstuk 10 besluit meteen discussie en valorisatie, waarin we de resultaten van dit proefschrift in een breder perspectief plaatsen en we speculeren over toekomstige ontwikkelingen rondom het onderwerp van dit proefschrift. 



\section{Addendum}

Curriculum vitae List of publications and presentations Dankwoord 



\section{Curriculum vitae}

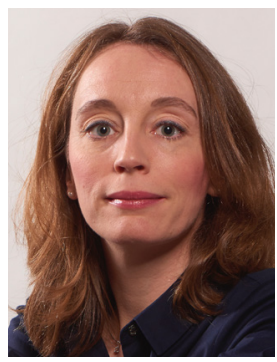

Marieke Reinders werd geboren op 18 oktober 1982 in Deurne. Ze groeide op in het Limburgse dorp Panningen, samen met haar zus en ouders. In 2000 behaalde zij haar gymnasiumdiploma aan het Bouwens van der Boijecollege in Panningen. In 2000 begon zij aan de studie geneeskunde aan de Universiteit van Maastricht en in 2006 studeerde zij cum laude af. Nadat zij een half jaar als poortarts op de spoedeisende hulp werkte in ziekenhuis Bernhoven in Veghel, kreeg zij een baan als arts niet in opleiding tot specialist op de afdeling dermatologie van het Catharina Ziekenhuis in Eindhoven. In 2007 werd zij aangenomen voor de opleiding tot dermatoloog in het Leids Universitair Medisch Centrum (opleider: R. Willemze). Tijdens deze opleiding kreeg zij de mogelijkheid om zich de Mohs' micrografische chirurgie eigen te maken in het Catharina Ziekenhuis in Eindhoven. Vanaf 2012 werkt zij als dermatoloog in het Maastricht Universitair Medisch Centrum. Marieke Reinders is getrouwd met Roel Hendrickx en zij wonen samen met hun twee zonen, Thomas en Maarten, in Roermond. 



\section{List of publications}

Gielen RC, Reinders MG, Koillinen HK, Paulussen AD, Mosterd K, van Geel M. PTCH1 isoform $1 \mathrm{~b}$ is the major transcript in the development of basal cell nevus syndrome. J Hum Genet. J Hum Genet. 2018 Sep;63(9):965-969

Reinders MG, van Hout AF, Cosgun B, Paulussen AD, Leter EM, Steijlen PM, Mosterd K, van Geel M, Gille JJ. New mutations and an updated database for the patched-1 (PTCH1) gene. Mol Genet Genomic Med. 2018 Mar 25

Reinders MG, Terra JB, Reyners AK, Aarts MJ, de Haas ER, Mosterd K. Vismodegib for basal cell carcinoma: targeted therapy in case of locally advanced or metastasised disease. Ned Tijdschr Geneeskd. 2016;160(0):D187

Reinders MG, Boersma HJ, Leter EM, Vreeburg M, Paulussen AD, Arits AH, Roemen GM, Speel EJ, Steijlen PM, van Geel M, Mosterd K. Postzygotic mosaicism in basal cell naevus syndrome. Br J Dermatol. 2016 Sep 22

Reinders MG, Brinkhuizen T, Soetekouw PM, Kelleners-Smeets NW, Hamid MA, Mosterd K. Epidermal cyst formation and hyperkeratosis in a patient treated with vismodegib for locally advanced Basal cell carcinoma. Acta Derm Venereol. 2015 May;95(5):618-9

Reinders MG. Hoofdstuk 5.2 Lentigo maligna. Handboek dermato-oncologie. RC Beljaards, HAM Neumann, W Bergman. 2015

Brinkhuizen T, Reinders MG, van Geel M, Hendriksen AJ, Paulussen AD, Winnepenninckx VJ, Keymeulen KB, Soetekouw PM, van Steensel MA, Mosterd K. Acquired resistance to the hedgehog pathway inhibitor vismodegib due to smoothened mutations in treatment of locally advanced basal cell carcinoma. J Am Acad Dermatol. 2014 Nov;71(5):1005-8

Reinders MG, Dirix L, Mosterd K, van Doorn R. Vismodegib in metastasised basal cell carcinoma. Ned Tijdschr Geneeskd. 2013;157(12):A6011

Reinders MG, Kukutsch NA. Dermatoscopie Quiz (monthly). Ned Tijdschr Dermatol Venereol 2012

Reinders MG, Kukutsch NA. Genital edema in childhood: harbinger of Crohn's disease? J Am Acad Dermatol. 2011 Aug;65(2):449-50 
Reinders MG, Vermeer MH. Carcinoma erysipeloides in breast cancer. Surgery. 2010 Nov;148(5):1040-1

Reinders MG, Hoefnagel JJ, Fransen van de Putte DE, van Doorn R. Het Bannayan-RileyRuvalcaba syndroom: onderdeel van het PTEN hamartoom tumor syndroom. Ned Tijdschr Dermatol Venereol. 2010; 20(5)

Reinders MG, Bergman W. Psoriasis capitis. Modern Medicine. Nov 2009

Reinders MG, Pavel S. Wat voegt UVA-1 lichttherapie toe aan de perifere praktijk. Wat zijn de academische ervaringen? Dermatologen vademecum. Aug 2009

Reinders MG, Pavel S. Wat is UVA-1 lichttherapie en wat zijn de indicaties? Vademecum Huisartsen. Aug 2009

Nijenhuis RJ, Jacobs MJ, Jaspers K, Reinders MG, van Engelshoven JM, Leiner T, Backes WH. Comparison of magnetic resonance with computed tomography angiography for preoperative localization of the Adamkiewicz artery in thoracoabdominal aortic aneurysm patients. J Vasc Surg 2007; 45(4) 


\section{List of presentations}

Genetic profiling of basal cell carcinomas detects postzygotic mosaicism in basal cell naevus syndrome.

Poster presentation, Annual Symposium of the Dutch Society of Human Genetics, 2018

Genetic mosaicism in basal cell naevus syndrome.

Grow School for Oncology and Developmental Biology MUMC, Pizza meeting, Maastricht, 2018

Genetic mosaicism in basal cell naevus syndrome.

Annual scientific meeting of the Dutch Association for Experimental Dermatology, Lunteren, 2018

Resistance for vismodegib in basal cell carcinoma treatment.

Annual meeting of the Dutch Association for Dermatology and Venereology, Maastricht, 2017

Multidisciplinaire behandeling van huidkanker.

Huidkanker, een gezamenlijke strijd voor een behandeling op maat, Oncologie symposium, Maastricht 2016

Huidplastieken in de praktijk.

Dermatologen in opleiding dagen, Amersfoort, 2015

Post-operatieve zorg en complicaties.

Workshop: eenvoudig sluiten van defecten in het gelaat.

COCOM Dermatochirurgie en flebologie, 2014 en 2017

Ulcus cruris, veneuze versus arteriële insufficiëntie.

Wondsymposium. LUMC, Leiden, 2012

Erfelijke tumor syndromen.

EADV review. WTC, Amsterdam, 2011

An exceptional large Mohs' case.

$20^{\text {th }}$ EADV Congress. Lisbon, Portugal, 2011

Gemetastaseerd basaalcelcarcinoom bij basaalcelnaevussyndroom.

Oncologie in de parel van de Ardennen. Dermato-oncologie congres. Spa, België, 2010

CT- versus MR-angiography for visualization of the Adamkiewicz artery.

Poster presentation, 10 ${ }^{\text {th }}$ Maastricht Medical Students Research Conference, Maastricht, 2006 



\section{Dankwoord}

Het is af! Graag wil ik iedereen bedanken die, op welke manier dan ook, een bijdrage heeft geleverd aan dit proefschrift: coauteurs, beoordelings- en promotiecommissie, medewerkers van het laboratorium dermatologie en klinische genetica, collega's van de afdeling pathologie en de patiënten zonder wie er geen data waren geweest. In het bijzonder wil ik de volgende personen noemen:

Mijn promotor, professor Steijlen. Beste Peter, bedankt voor het vertrouwen en de ruimte die je me hebt gegeven om dit proefschrift af te ronden.

Mijn copromotor, dr. Mosterd. Lieve Klara, dank voor het aandragen van ideeën om dit proefschrift vorm te geven naast mijn werk als staflid. Je bent niet alleen een fantastische copromotor, maar ook een fijne collega, met wie ik erg graag en gezellig samenwerk.

Mijn copromotor, dr. van Geel. Beste Michel, bedankt voor je nuchtere visie op de materie. Ik kon altijd bij je terecht met moeilijke en makkelijke genetische vragen. Vaak nam je precies dat uit handen, waar ik minder goed in was.

WESP-studenten Betûl Cosgun (inmiddels AIOS dermatologie) en Twan van Hout (inmiddels $\mathrm{HAIO}$ ), bedankt voor jullie inzet en de enorme hoeveelheid werk die jullie hebben verricht.

Dr. Brinkhuizen, lieve Tjinta, dank voor de fijne samenwerking rondom het schrijven van onze twee gezamenlijke publicaties.

Dr. mr. L.G. Reinders, beste Hans, bedankt voor het aanbrengen van correcties in de Engelse tekst van de introductie en discussie van dit proefschrift.

Collega stafleden MUMC en CZE, dank voor de fijne werksfeer en het warme onthaal toen ik als nieuweling vanuit Leiden de staf kwam versterken. (Oud-) AIOS in het MUMC, de opleiding gaat mij aan het hart. Met jullie samenwerken zorgt voor veel energie en is enorm leerzaam.

Lieve dames van het secretariaat, bedankt voor al jullie hulp. Verpleegkundigen, doktersassistenten en baliemedewerksters op de poli, bedankt voor de plezierige samenwerking.

Staf LUMC en MC Haaglanden, bedankt voor de fijne opleidingstijd. Oud-maatschap dermatologie CZE, jullie hebben mij als ANIOS geënthousiasmeerd voor de dermato-oncologie en chirurgie, dank daarvoor! Oud-collega arts-assistenten uit Eindhoven en Leiden, het is alweer een tijdje geleden, maar dank voor alle gezelligheid tijdens en voorafgaand aan de opleiding en nu nog als we elkaar weer zien op congressen. 
Lieve vrienden en vriendinnen, lieve schoonfamilie, dank voor alle gezelligheid en ontspanning buiten het werk. We wonen niet allemaal bij elkaar om de hoek, maar zorgen ervoor dat we elkaar regelmatig zien. Lieve Els, we hebben al veel belangrijke momenten gedeeld, bijzonder dat je naast me staat als paranimf.

Lieve mama en papa, zonder jullie was het niet gelukt. Jullie zijn voor mij altijd een onvoorwaardelijke steun geweest met onuitputtelijke energie. Niets is te veel en alles is mogelijk. Jullie zijn een enorm liefdevolle oma en opa voor de jongens. Bedankt daarvoor.

Lieve Carlijne, met een zus als jou is er altijd een luisterend oor, een maatje, een steun en toeverlaat. Dankjewel.

Lieve, lieve Thomas en Maarten, met jullie beleef je nog eens wat. Wat een energie en plezier geven jullie mij!

Allerliefste Roel, dankjewel voor alles. 